


\section{Opportunities and challenges for sustainable production and marketing of gums and resins in Ethiopia}

Editors

Mulugeta Lemenih

Habtemariam Kassa 
(c) 2011 Center for International Forestry Research

All rights reserved

ISBN 978-602-8693-57-8

Lemenih, M. and Kassa, H. (eds) 2011 Opportunities and challenges for sustainable production and marketing of gums and resins in Ethiopia. CIFOR, Bogor, Indonesia

Photographs by Mulugeta Lemenih or Habtemariam Kassa, unless otherwise indicated.

\author{
CIFOR \\ J. CIFOR, Situ Gede \\ Bogor Barat 16115 \\ Indonesia \\ T $+62(251) 8622-622$ \\ F +62 (251) 8622-100 \\ E cifor@cgiar.org
}

\title{
www.cifor.cgiar.org
}

Any views expressed in this publication are those of the authors. They do not necessarily represent the views of CIFOR, the authors' institutions or the financial sponsors of this publication. 


\section{Contents}

Abbreviations $\quad$ vi

Acknowledgements vii

Foreword viii

1 Challenges and forest-based opportunities in the drylands of Ethiopia 1

$\begin{array}{ll}1.1 \text { Drylands of Ethiopia } & 1\end{array}$

1.2 Challenges facing the drylands of Ethiopia 2

$\begin{array}{lll}1.3 & \text { Opportunities for forest-based enterprises } & 4\end{array}$

$\begin{array}{lll}1.4 & \text { Dryland vegetation resources of Ethiopia }\end{array}$

2 Resource base of gums and resins and challenges of productivity 13

$\begin{array}{ll}2.1 \text { Introduction } & 13\end{array}$

2.2 Gum- and resin-producing species and their spatial coverage 13

$\begin{array}{ll}2.3 & \text { Yield and productivity } \\ 2.4 & 24\end{array}$

$\begin{array}{ll}2.4 & \text { Economic and ecological significance }\end{array}$

2.5 Degradation of gum and resin resources and major causes 33

$\begin{array}{ll}2.6 & \text { Options for restoration } \\ \end{array}$

3 Production, handling and quality control 47

$\begin{array}{ll}3.1 & \text { Introduction } \\ 3.2 & 47\end{array}$

3.2 History of gum and resin production in Ethiopia 47

3.3 Production processes and gum handling 48

$\begin{array}{lll}3.4 & \text { Post-harvest handling } & 55\end{array}$

3.5 Quality of gums and resins 56

$\begin{array}{lll}3.6 & \text { Quality control } & 63\end{array}$

3.7 Challenges related to production and supply 64

4 Value-added processing and marketing of gums and resins 69

$\begin{array}{lll}4.1 & \text { Introduction } & 69\end{array}$

4.2 Industrial application and local use of gums and resins 70

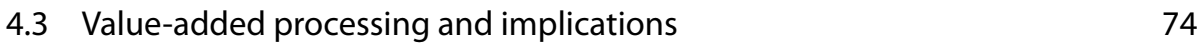

$\begin{array}{lll}4.4 & \text { Advantages of value-added processing } & 75\end{array}$

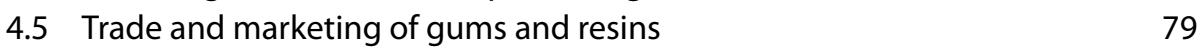

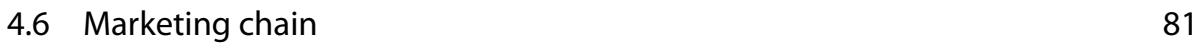

5 Challenges, opportunities and actions for sustainable gum $\begin{array}{ll}\text { and resin production } & \mathbf{8 7}\end{array}$

5.1 Challenges and opportunities $\quad 87$

$\begin{array}{lll}5.2 & \text { Future actions } & 91\end{array}$ 


\section{List of tables and figures}

\section{Tables}

1.1 Estimated extent of drylands in Ethiopia 1

2.1 Common and potential gums and resins producing Acacia, Commiphora $\quad 14$ and Boswellia species found in the drylands of Ethiopia

2.2 Estimated extent of area containing vegetation with gum- and resin- 16 producing species in Ethiopia by regional state

2.3 Commercial gums and resins with botanical sources and local designations

2.4 Gum- and incense-producing tree species found in the Borana area 22

2.5 Estimated potential and annual production of gum and incense in 25 Ethiopia

2.6 Natural gums (gum olibanum, gum arabic, myrrh/opoponax) exported 25 from Ethiopia by various enterprises during the past 15 years

2.7 Comparison of actual and potential gum and resin production in 26 Ethiopia, based on figures for 2003/04

2.8 Local uses of gums and resins and their source species in lowland areas $\quad 30$ of Ethiopia

3.1 Grades of gum olibanum (Tigray type) 55

3.2 Data on the physico-chemical properties of gum arabic from A. senegal 58 from the Central Rift Valley, Ethiopia

3.3 Assessment of gum arabic from Central Rift Valley of Ethiopia against $\quad 59$ international specifications and gums from other sources

3.4 Composition (\%) of the essential oils of different grades (G-1A to G-5) of 62 frankincense from B. papyrifera

4.1 Major world and African exporters of gum arabic in $2005 \quad 76$

4.2 Major world and African exporters of gums and resins other than gum 77 arabic in 2005

4.3 Natural gum and resin exports from Ethiopia by destination in 2005/06 78 Ethiopian Fiscal Year

4.4 Global imports of gum arabic and other gums and resins ('natural 80 gums') in 2006

4.5 Minimum, maximum and average selling prices (Birr/quintal) of 80 different products by main players

\section{Figures}

1.1 Examples of dry afromontane forests in Ethiopia 7

1.2 Combretum-Terminalia (broad-leaved deciduous) woodlands dominated 7 by B. papyrifera species (a) during the rainy season and (b) during the dry season in the western lowlands of Ethiopia (Metema) 
1.3 Acacia-Commiphora (small-leaved deciduous) dryland forest dominated

by Commiphora and Boswellia species in the southeastern and northeastern parts of Ethiopia

1.4 Semi-desert vegetation with scattered Commiphora and other species in northeastern Ethiopia (Afar)

2.1 Some of the gum- and incense-producing species in the woodlands of Ethiopia

2.2 (a) White Tigray type incense of various grades obtained from

B. papyrifera, and (b) black Borana incense obtained from B. neglecta

2.3 (a) True myrrh from C. myrrha and (b) opoponax from C. guidotti species 18

2.4 (a) Gum arabic from A. senegal var. senegal and (b) var. kerensis 19

2.5 Population structure of $A$. senegal at 2 contrasting sites in Central Rift 21 Valley of Ethiopia: (a) protected and (b) farmland

2.6 Population structure of B. papyrifera species in Metema, Ethiopia:

(a) during the rainy season and (b) during the dry season

2.7 Diameter class distribution of 3 gum- and resin-producing species in Borana showing impacts of human disturbances on population structure

2.8 Women sorting and grading gums and resins

2.9 Population structure of B. papyrifera in Metema district, northwestern

Ethiopia (The predicted curve was derived using the Weibull distribution function)

2.10 Settlement parcels and agricultural fields in the midst of Boswellia forest in Metema district

2.11 Change in land cover/land use over a 15-year period (percentage)

2.12 High livestock populations in the dryland forests of (a) Metema and (b)

Borana lowlands, resulting in overgrazing

2.13 Dry forests of Metema district damaged by fire

2.14 Signs of damage from improper tapping

2.15 Vegetative propagation of B. papyrifera (top) and planted stand of A. senegal (bottom)

3.1 Historical development of commercial gum and resin production in Ethiopia

3.2 (a) Two of the most commonly used tapping tools (mingaf and sonke) and (b) tapping an incense tree

3.3 Solidifying tear of frankincense after artificial wounding of B. papyrifera

3.4 Tapping of B. papyrifera after 1 year (left), 2 years (centre) and more than 2 years (right)

3.5 Picking of incense tears from stems after maturity and collection vessels used in the north

3.6 (a) Naturally oozing gum of $A$. senegal and (b) incense from $B$. neglecta

3.7 (a) Children collecting gum and incense and (b) collection vessel

3.8 Evolution of gum and resin exploitation systems in 3 sites in Ethiopia 54

3.9 Shades constructed for incense seasoning at or near production sites $\quad 55$

3.10 (a) Commonly used collection vessels and (b) transportation sacks 


\section{Abbreviations}

$\begin{array}{ll}\text { ADA } & \text { Austrian Development Agency } \\ \text { ASAL } & \text { Arid and semi-arid land } \\ \text { masl } & \text { Metres above sea level } \\ \text { BP } & \text { British Pharmacopoeia } \\ \text { CBC } & \text { Convention on Biodiversity Conservation } \\ \text { CCD } & \text { Convention to Combat Desertification } \\ \text { CIFOR } & \text { Center for International Forestry Research } \\ \text { CRV } & \text { Central Rift Valley of Ethiopia } \\ \text { DBH } & \text { Diameter at breast height } \\ \text { EC } & \text { Ethiopian calendar } \\ \text { EFAP } & \text { Ethiopian Forestry Action Program } \\ \text { EFY } & \text { Ethiopian fiscal year (from 7 July to 6 July) } \\ \text { EIAR } & \text { Ethiopian Institute of Agricultural Research } \\ \text { FAO } & \text { Food and Agricultural Organization of the United Nations } \\ \text { FRC } & \text { Forest Research Centre } \\ \text { IP } & \text { International Pharmacopeia } \\ \text { IPCC } & \text { Intergovernmental Panel for Climate Change } \\ \text { JECFA } & \text { Joint Expert Committee for Food Additives } \\ \text { MOARD } & \text { Ministry of Agriculture and Rural Development } \\ \text { NCSS } & \text { National Conservation Strategy Secretariat } \\ \text { NGARA } & \text { Network for Natural Gums and Resins in Africa } \\ \text { NGO } & \text { Nongovernmental organisation } \\ \text { NGPME } & \text { Natural Gum Processing and Marketing Enterprise } \\ \text { NTFP } & \text { Non-timber forest product } \\ \text { P } & \text { Precipitation } \\ \text { PASDEP } & \text { Plan for Accelerated and Sustainable Development to End Poverty } \\ \text { PET } & \text { Potential evapotranspiration } \\ \text { TLU } & \text { Tropical livestock units } \\ \text { UNFCCC } & \text { United Nations Framework Convention on Climate Change } \\ \text { USD } & \text { United States dollar } \\ \text { USP } & \text { United States Pharmacopeia } \\ \text { WHO } & \text { World Health Organization } \\ & \end{array}$




\section{Acknowledgements}

We would like to thank the Swedish International Development Cooperation Agency (Sida) for financing CIFOR's dry forest project in Ethiopia (2007-2009), which led to the compilation of an earlier version of this publication. We gratefully acknowledge the Austrian Development Agency (ADA) for financing CIFOR's ongoing community forestry project in Ethiopia. ADA's support has enabled us to revise, edit, print and distribute this publication to users. Thanks are also due to all those who contributed as authors. Unless indicated otherwise, all photographs were contributed by the editors. 


\section{Foreword}

Ethiopia has widely differing agro-ecological zones, commonly classified into highlands - areas above 1500 metres above sea level - and lowlands, those below. Arid and semi-arid lands (ASALs), a class of drylands, are important in both the highlands and the lowlands of Ethiopia. These areas are povertystricken and largely food insecure, despite being endowed with resources that could provide alternative and sustainable livelihoods if they were properly exploited and developed. Vegetation in Ethiopia's ASALs includes diverse plant species that produce commercially important oleo-gum resins such as gum arabic, frankincense, myrrh and opoponax. These products have been traded both locally and internationally for centuries and make a significant contribution to the national and local economies. They also have a range of industrial applications.

The production of gums and resins can be successfully integrated with livestock husbandry, apiculture and ecotourism, thus helping to diversify and sustain dryland livelihood options and increase household income. The important role of dry forests in soil and water conservation, biodiversity management and the fight against desertification is well known. Nonetheless, management of dry forests in order to enhance the economic and ecological benefits of gum- and resinproducing tree species is limited. One of the major constraints on promoting sustainable management of dry forests and their valuable tree species is the lack of awareness of their importance combined with inadequate knowledge about sustainable production and marketing of their products. Building understanding of the constraints and opportunities is an important step in closing this knowledge gap.

Our partners in Ethiopia and in the region requested the collection and compilation of available information on the production and marketing of gums and resins. The result is this publication, which sets out the need for vegetation-based land management as a sustainable option for the country's drylands, and highlights the potential and constraints related to the production and marketing of gums and resins in Ethiopia. We hope the information in this publication proves relevant for policymakers, researchers, teachers, development practitioners, investors and the public at large. 


\section{Chapter 1}

\section{Challenges and forest-based opportunities in the drylands of Ethiopia}

Mulugeta Lemenih ${ }^{1}$ and Habtemariam Kassa ${ }^{2}$

\subsection{Drylands of Ethiopia}

Drylands comprise the greater part of Ethiopia's landmass. Drylands are variously defined as areas characterised by a seasonal climate with several months of drought (Murphy and Lugo 1986), areas having a growing period of $\leq 180$ days or areas with an aridity index of $\leq 0.5$ (UNESCO 1979). UNESCO's aridity index refers to the ratio of potential evapotranspiration (PET) to precipitation $(\mathrm{P})$; thus, all lands for which $\mathrm{PET} / \mathrm{P} \leq 0.5$ are classified as drylands. This definition encompasses areas traditionally described as arid, semi-arid and dry subhumid, as well as the driest hyper-arid areas. Arid and semi-arid lands (ASALs) are estimated to cover $560000-615000 \mathrm{~km}^{2}(50-55 \%)$ of the total landmass of Ethiopia. When dry subhumid areas are included in the definition, the total extent of the country's drylands may be $860000-915000 \mathrm{~km}^{2}(76-81 \%)$ (Table 1.1). Drylands thus predominate across the lowlands and highlands in the country's north, east, west, central, south, southeast and northwest regions.

Table 1.1 Estimated extent of drylands in Ethiopia

\begin{tabular}{lcc}
\hline Bioclimatic zone & \multicolumn{2}{c}{ Area $\left(\mathbf{( ' 0 0 0 ~}^{\text {km }}\right.$ ) } \\
& $\begin{array}{c}\text { Lowest } \\
\text { estimate }\end{array}$ & $\begin{array}{c}\text { Highest } \\
\text { estimate }\end{array}$ \\
\hline Hyper-arid & 53 & 55 \\
Arid & 300 & 310 \\
Semi-arid & 207 & 250 \\
Dry subhumid & 300 & 300 \\
Total & 860 & 915 \\
\hline
\end{tabular}

Source: Lemenih and Teketay (2004)

1 Hawassa University, Wondo Genet College of Forestry and Natural Resources, Shashemene, Ethiopia 2 Center for International Forest Research (CIFOR) 
The drylands of Ethiopia support a significant proportion of the country's human and livestock populations, although the population is heavily concentrated in the dry subhumid region. ASALs, which are the focus of this publication, are relatively sparsely populated, home to only $12-15 \%$ of Ethiopia's 80 million people. Most of the people in ASALs are pastoralists and agro-pastoralists. They have long recognised the critical importance of sound management of the natural resource base in providing them with the diverse products and services that are important for their livelihoods. Thus, they have adopted pastoralism, which is a flexible, opportunistic and compatible production system, in the risk-prone ASAL environments. They also have selected highly adaptive and productive livestock species and breeds. Mobility is the norm of the production system to better exploit the various resources available during different seasons and in different locations.

Pastoralists place greater value on perennial vegetation than on annual crops because it has multiple functions, such as providing browse, particularly during the dry season, wood for carving, hut construction and energy, and a source of income from the sale of timber and non-timber products (Lemenih et al. 2003, Lemenih and Teketay 2004). The income from non-timber products such as gums and resins is crucial for food security in ASALs. Many of the gum and resin products obtained are traded internationally, generating considerable foreign currency earnings and supporting the national economy of Ethiopia and many other Sudano-Sahelian countries.

Demographic, environmental, socio-economic and political changes are putting pressure on the use and management of drylands. ${ }^{3}$ Today, many dryland communities are experiencing increasing hardships, frequent droughts and food insecurity, as well as a declining quality of life. Areas in Ethiopia's drylands are probably amongst those with the country's highest incidence of poverty and poor access to basic social services such as infrastructure, education and health services. Due to the general misconception that drylands are resource-poor areas, they have not attracted much investment or any significant development initiatives from either the private or the public sector. These problems are further compounded by stresses related to global climate change.

\subsection{Challenges facing the drylands of Ethiopia}

The drylands of Ethiopia are facing multiple natural and anthropogenic challenges. The low and erratic rainfall is probably the most important natural problem, limiting the possibility of sustainable livelihoods from crop and animal production. In about $22 \%$ of drylands, cultivation is not possible even with

3 Hereafter, unless otherwise indicated, the term 'drylands' is used to refer to ASALs. 
early-maturing crops (NCSS 1993, Hawando 1997). In the remaining areas, the unpredictable timing and low amounts of rainfall have always been a severe constraint on agricultural production. Agriculture in ASALs often requires additional investment, especially in irrigation facilities and other infrastructure (Steen 1994, Lemenih et al. 2003). Consequently, livestock production in the form of nomadic pastoralism has been the dominant land use system. However, in recent years, the upsurge in human and livestock population, recurrent droughts, severe land degradation and the consequent shortage of fodder and water have added further constraints on the sustainability of the pastoral land use system. Food insecurity is widespread in Ethiopia's ASALs, and food aid has become common.

Ethiopia's drylands are experiencing rapid changes in both the human and livestock populations. Several factors are behind the population growth, one of the most important being government-initiated resettlement programmes. Successive governments have used resettlement to the lowland dry forests as a strategy for reducing the food insecurity of vulnerable households in the degraded highland areas (Kebede 2006). In addition to the official resettlement programme, deteriorating livelihood conditions in the highlands due to land degradation have triggered large informal migration to the lowlands. These formal and informal resettlements are causing rapid demographic and land use changes in the drylands of Ethiopia.

Over most of the country's ASALs, nomadic pastoralism is gradually shifting to agro-pastoralism, and agro-pastoralists are being encouraged to become sedentary farmers. This changing mode of life coupled with the population increase has encouraged rapid villagisation and the emergence of urban centres. This in turn has increased the demand for timber products for construction and energy, triggering further deforestation over large areas of the drylands. Poor farming practices, population pressure, overgrazing, soil erosion, deforestation and the use of livestock manure and crop residue as fuel, combined with erratic rainfall, are leading to recurrent crop failures. Consequently, people often turn to harvesting and overharvesting of forest products, notably timber, to augment their household income, thus further driving land degradation and desertification. Desertification is a widely encroaching challenge across Ethiopia's drylands (Hawando 1997).

Global climate change is adding further stress to dryland areas. Ethiopia and similar African countries are likely to suffer most from the effects of climate change, even though their contribution to its causes is negligible on a global scale. The African continent as a whole is likely to be highly vulnerable to the effects of climate change not only because of increasing aridity and other climatic 
anomalies, but also because of the widespread poverty that limits the population's capacity to adapt to climate change. According to the Intergovernmental Panel on Climate Change (IPCC 2001), temperatures in land areas across the Sahara and semi-arid parts of Africa may increase by as much as $1.6^{\circ} \mathrm{C}$ by 2050 . Equatorial Africa might be about $1.4^{\circ} \mathrm{C}$ warmer. Mean annual precipitation has gradually declined during the past couple of decades, and the frequency of irregularities has increased. Projected rainfall changes indicate a decline by about $10 \%$ by 2050 over the Horn of Africa, and potential evapotranspiration is projected to increase by $5-10 \%$ (IPCC 2001). This will lead to increased moisture stress in the drylands, and hence further decline in crop and fodder production.

To summarise, with the growing human and livestock population, increased deforestation and land degradation, shrinking farm size, advancing desertification and poor infrastructure, in addition to gloomy scenarios in connection with global climatic changes, the prognosis for the drylands of Ethiopia looks grim. It is thus essential to enhance people's adaptive capacity and promote land use systems that contribute to increased environmental resilience and better livelihoods. The question, then, is what types of curative opportunity exist for these stressed and marginal lands?

\subsection{Opportunities for forest-based enterprises}

Despite the general perception that drylands are resource-poor areas, several studies indicate that the forests and woodlands in Ethiopia's drylands offer good opportunities for improving rural livelihoods and reducing poverty. Dry forests, which cover about 55-60\% of the country's drylands (WBISPP 2004), are important in terms of their contributions to human welfare and environmental health. Everywhere, dry forests provide diverse goods and services such as fodder, fuel, cash income, building materials and herbal medicines, and they help to protect the soil from erosion and to restore soil fertility. Most importantly, several species of the genera Acacia, Commiphora, Boswellia and Sterculia yield commercial plant gums and resins that have been traded since antiquity (EFAP 1994, Lemenih et al. 2003). The best known of these products are gum arabic, frankincense/gum olibanum, myrrh, opoponax and gum karaya. Ethiopia has one of the largest resource bases for commercial plant gum and resin production (Kuchar 1995, Tadesse et al. 2002). Studies have shown that the country's natural gums subsector offers viable investment options for invigorating economic development in the drylands (Lemenih 2005, Roukens et al. 2005). Moreover, global demand for these products is growing. Improving access to this global market could create economic incentives for farmers to sustainably manage the dry forests. Higher prices also encourage efforts to improve the quality of gums and resins. This in turn contributes to local and national economic growth. 
The collection, use and trade of gums and resins are age-old activities in Ethiopia. The subsector's contribution both to the national economy and to local communities cannot be overlooked. It offers one of the few opportunities available for dryland communities to supplement their cash incomes, particularly during dry seasons, and thus its role in food security is tremendous (Lemenih et al. 2003). The great potential for gum and resin production and marketing implies that the implementation of appropriate policy and resource management measures could enhance the socio-economic and ecological gains from the subsector (Tadesse et al. 2002, Lemenih et al. 2003, Eshete et al. 2005). Another advantage of the gum and resin resource base is that production can be integrated with other forms of production, particularly with livestock production, apiculture, sericulture and civiculture, to optimise returns per unit area.

Tree-based management of drylands has a number of advantages. It helps fight desertification, promotes conservation of biodiversity and assists farmers to better adapt to climate change (Lemenih and Teketay 2004). By so doing, it helps maintain healthy social and ecological systems. The production of gums and resins, when properly practised, is non-destructive to either trees or the ecosystem. The trees remain standing to continue providing ecosystem services. Thus, this development option enables the successful marriage of sustainable livelihood provision and ecosystem conservation. Gum- and resin-producing species are adapted to extreme aridity, which makes them appropriate options for dryland conservation and combating desertification.

Ethiopia is a party to and has ratified several international conventions of direct relevance to dryland environments, such as the UN Convention to Combat Desertification (CCD), Convention on Biodiversity Conservation (CBC) and Framework Convention on Climate Change (UNFCCC). Promoting tree-based land use systems in the drylands significantly assists the country to meet its requirements under these conventions. The following points summarise how gums and resins can contribute to the development of dryland areas in Ethiopia.

- Gum and resin products and their vegetation resources provide substantial economic incentives at local and national levels, and thus contribute to food security and improved livelihoods.

- The vegetation resources can offer alternative development opportunities through integration with other economic sectors such as livestock husbandry and apiculture to diversify income sources and optimise return per unit area. In particular, livestock husbandry, which is the dominant land use and principal capital asset of the pastoral families inhabiting ASALs, heavily depends on the same vegetation as a source of fodder.

- Local people can use some of the gums and resins from these plants as emergency food during famine periods, making them a safety net. 
- $\quad$ The plant can help in combating desertification and assisting dryland communities to adapt to climatic changes (Teketay and Lemenih 2004).

Despite this potential, exploitation of these resources has not yet generated useful gains. People in the drylands of Ethiopia continue to experience severe poverty and critical food insecurity. Factors contributing to the neglect of these resources include (1) lack of awareness of the potential of the resources, particularly non-timber forest products (NTFPs); (2) lack of clearly defined policy on the development of drylands; and (3) ill-informed agricultural development strategies that solely focus on agricultural expansion. Nevertheless, the national and local contributions from these dryland vegetation resources are increasing.

\subsection{Dryland vegetation resources of Ethiopia}

Dry forests comprise Ethiopia's largest vegetation resource. The structure and composition of the country's dry forests are diverse, reflecting their wide distribution across various climatic types and a broad altitudinal range spanning from the salt marshes of the Afar depression below sea level to the dry cool subafroalpine mountains. Structurally, dry forests cover the spectrum from a 'real' forest (closed canopy with tall trees) to desert scrub. Compositionally, the forests are rich in endemic plant and animal species, especially in the lowlands in the country's southeast. Perhaps one in four of Ethiopia's plant species is found in this part of the country, which is characterised by its high diversity of Acacia and Commiphora species. The latter are particularly important, as about half of the 150-200 species of the genus are endemic to the small area of southeastern Ethiopia, northeastern Kenya and Somalia.

According to the Conservation Strategy of Ethiopia (CSE 1997), 9 broad vegetation types are recognised in Ethiopia. Of these, 7 can be designated as dry forests: (1) dry evergreen afromontane vegetation; (2) Combretum-Terminalia (broad-leaved) deciduous woodlands; (3) Acacia-Commiphora (small-leaved) deciduous woodlands; (4) lowland dry forests; (5) riparian (wetland) vegetations; (6) lowland semi-desert and desert vegetation; and (7) evergreen scrubs.

\subsubsection{Dry afromontane vegetation}

Vegetation in the seasonally dry mountainous areas in the central, eastern and northern highlands of Ethiopia is collectively classified as dry afromontane vegetation (Figure 1.1). Afromontane vegetation is found in areas at 1500-3200 metres above sea level (masl). The drier eastern areas are mainly composed of Juniperus procera and/or Afrocarpus falcatus species, with Acacia abyssinica and Olea europaea commonly appearing together also. Other trees in the area include Prunus africana, Apodytes dimidiata, Allophylus abyssinica and Euphorbia 
ampliphylla. This class of vegetation is poor with respect to commercial gum- and resin-producing species, but is rich in species with other commercial NTFPs, such as Prunus africana, a well-known medicinal plant.

\subsubsection{Combretum-Terminalia (broad-leaved) deciduous woodlands}

Broad-leaved deciduous forests and woodlands are found in the western and northwestern lowlands of Ethiopia. Land in the moister western lower altitudes have deeper soils and support deciduous forests with considerable ground cover (Figure 1.2), which are the extension of Sudano-Sahelian vegetation formation (Ogbazghi 2001). Fires occur frequently, especially following human influxes from the surrounding highlands. Although natural fire has caused no noticeable deterioration and plants and animals are adapted to it, the frequency and high intensity of fire caused by human-related activities have harmed vegetation resources in recent years.
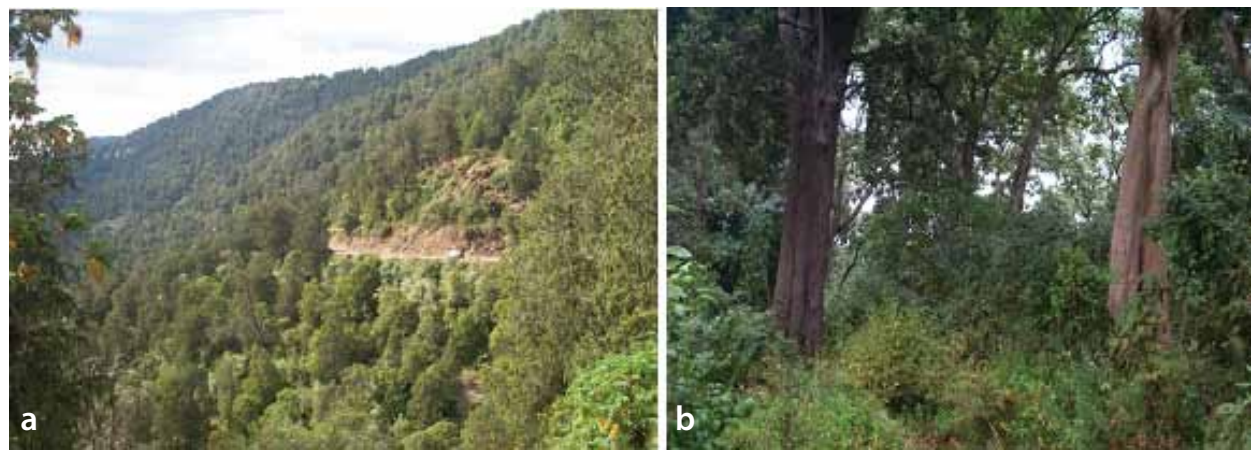

Figure 1.1 Examples of dry afromontane forests in Ethiopia: (a) Juniperus proceradominated dry afromontane forest of Bale, and (b) Afrocarpus falcatus-dominated dry afromontane forests of Munessa, central Ethiopia. Photos $\odot$ M. Lemenih
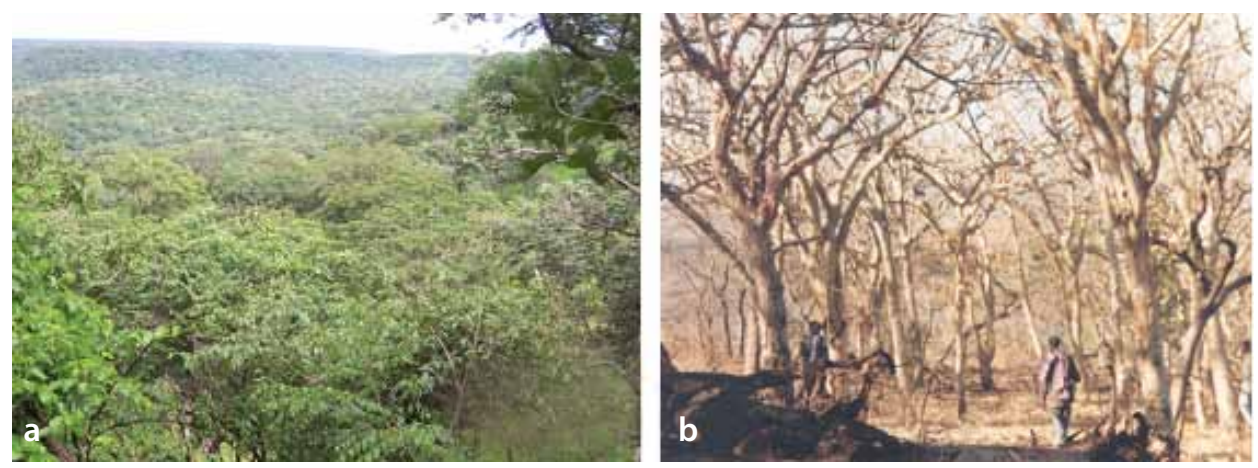

Figure 1.2 Combretum-Terminalia (broad-leaved deciduous) woodlands dominated by B. papyrifera species (a) during the rainy season and (b) during the dry season in the western lowlands of Ethiopia (Metema). Photos $\odot$ M. Lemenih (a); G. Fitwi G. (b) 
These woodlands represent the main B. papyrifera-growing regions in the Horn of Africa (Asfaw 2006).

The main tree species making up the broad-leaved deciduous woodlands of western Ethiopia other than B. papyrifera include Balanites aegyptiaca, Combretum adenogonium, C. collinum, C. molle, Terminalia spp., Grewia spp. Gardenia spp., Flueggea virosa, Acacia polyacantha, A. senegal, A. seyal and Sterculia setigera. Of these, B. papyrifera, A. polyacantha, A. senegal, A. seyal and Sterculia setigera are known to yield commercial gums and resins.

\subsubsection{Acacia-Commiphora (small-leaved) deciduous woodlands}

This vegetation type is predominantly found in the southern, central (Rift Valley) and eastern lowlands of the country at altitudes below 1900 masl. Plant species characteristic of this vegetation type are drought-tolerant small-leaved trees and shrubs, such as Acacia tortilis, A. seyal, A. senegal, A. etbaica, A. sieberiana, A. mellifera, A. drepanolobium, Commiphora africana, C. myrrha, C. fluviflora, C. habessinica, C. paolii, C. crenulata, C. boranensis, C. guidotti, C. erythraea, C. schimperi, C. ogadensis, C. rostrata, C. serrulata, C. gileadensis, C. hildebrandtii, C. erosa, C. cyclophylla, C. corrugata, B. microphylla, B. ogadensis, B. neglecta, $B$. rivae, Balanites aegyptiaca and Maytenus senegalensis (Figure 1.3). This
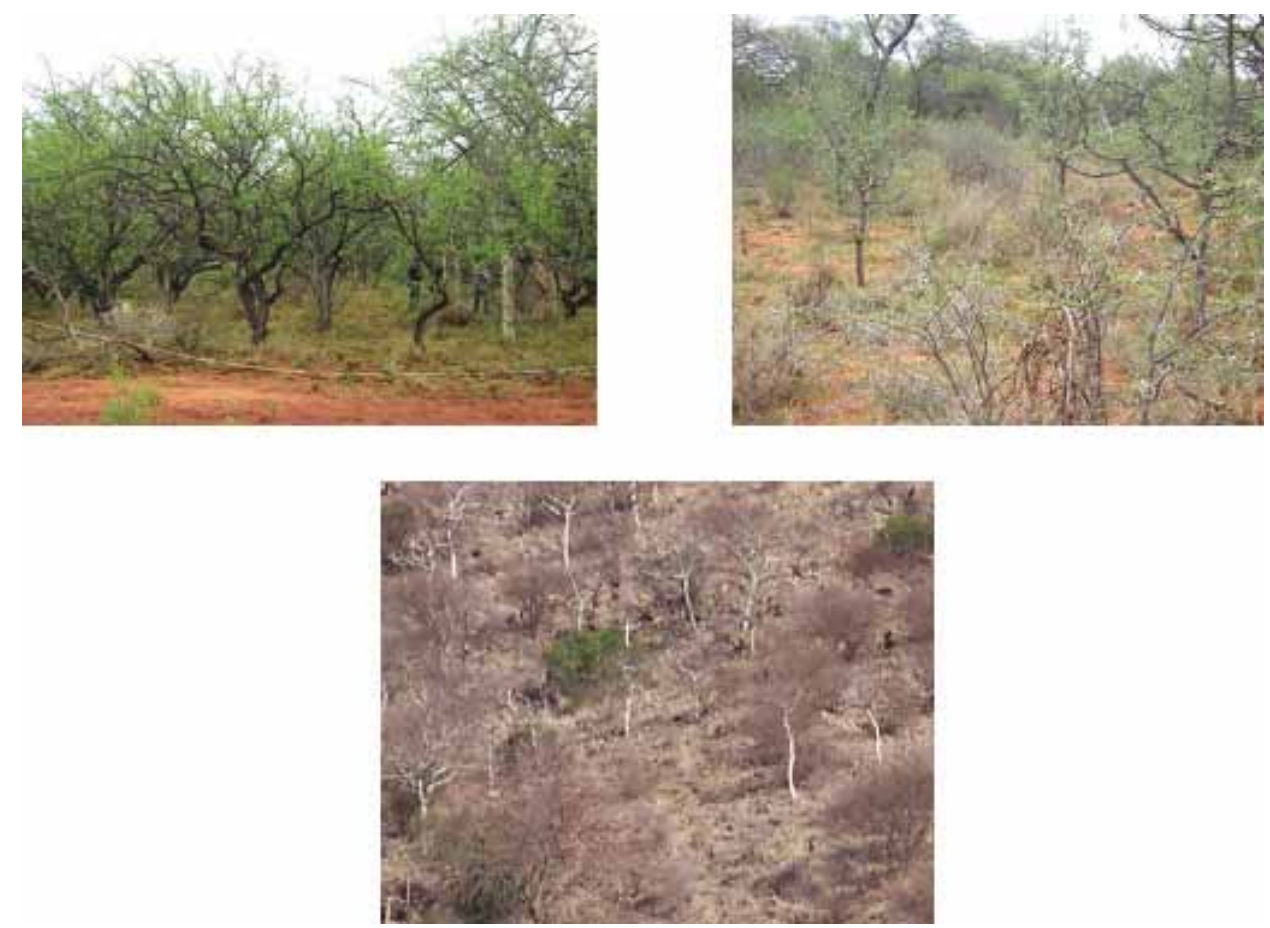

Figure 1.3 Acacia-Commiphora (small-leaved deciduous) dryland forest dominated by Commiphora and Boswellia species in the southeastern and northeastern parts of Ethiopia. Photo ๑ A. Worku (2006) (top); M. Lemenih (bottom) 
vegetation formation is the richest in terms of commercial gum- and resinproducing species of the genera Acacia, Commiphora and Boswellia.

\subsubsection{Lowland dry forests}

In Ethiopia, lowland dry forests are found only in the Baro lowlands of Gambela Regional State. Apart from common trees, this lowland forest is characterised by the presence of species that are widely distributed across tropical Africa and West Africa up to Ghana (Friis 1992). The forest does not contain any of the common gum- and resin-producing tree and shrub species identified in other dryland vegetations in Ethiopia.

\subsubsection{Riparian (wetland) vegetation}

In the plains of the Rift Valley, water gathers from the surrounding undulating terrains, creating swamps and wetlands. Such wetlands are abundant in the lake regions of the Ethiopian Rift Valley and along the plains of Awash and other major rivers. Although human activity has greatly damaged the wetland and riparian forests of these areas, significant patches remain in localised areas such as around Lake Langano and between the Abaya and Chamo Lakes in Arbaminch. Major species in such vegetation types are Celtis africana, Ficus sycamorus, Mimusops kummel, Maytenus senegalensis, Acacia spp., Syzygium guineense and Afrocarpus falcatus.

\subsubsection{Lowland semi-desert and desert vegetation}

Desert and semi-desert areas are found along the borders of eastern and southern Ethiopia at altitudes below 900 masl. Rainfall in these areas is low and very erratic. Vegetation consists of deciduous shrubs, mostly Acacia species, together with sparse evergreen shrubs and succulents (Figure 1.4). Commiphora and Boswellia species also exist here and, wherever available, they, along with Acacia species, provide the highest-quality gum and resin in this vegetation type (Lemenih et al. 2003).

\subsubsection{Evergreen scrub}

Evergreen scrub occupies the undulating and steep slopes of the highland plateaus. It covers vast areas, particularly in the north, west and east in Wello, Tigray, Shewa, Wollega and Hararghe, and is even expanding by overtaking areas where forests have deteriorated. The woody vegetation mainly consists of plants with small, tough, leathery leaves such as Euclea schimperi, Dodonaea angustifolia, Carissa edulis, Scolopia theifolia, Rhamnus staddo, Myrsine africana, Calpurnia aurea and Jasminum abyssinicum. 


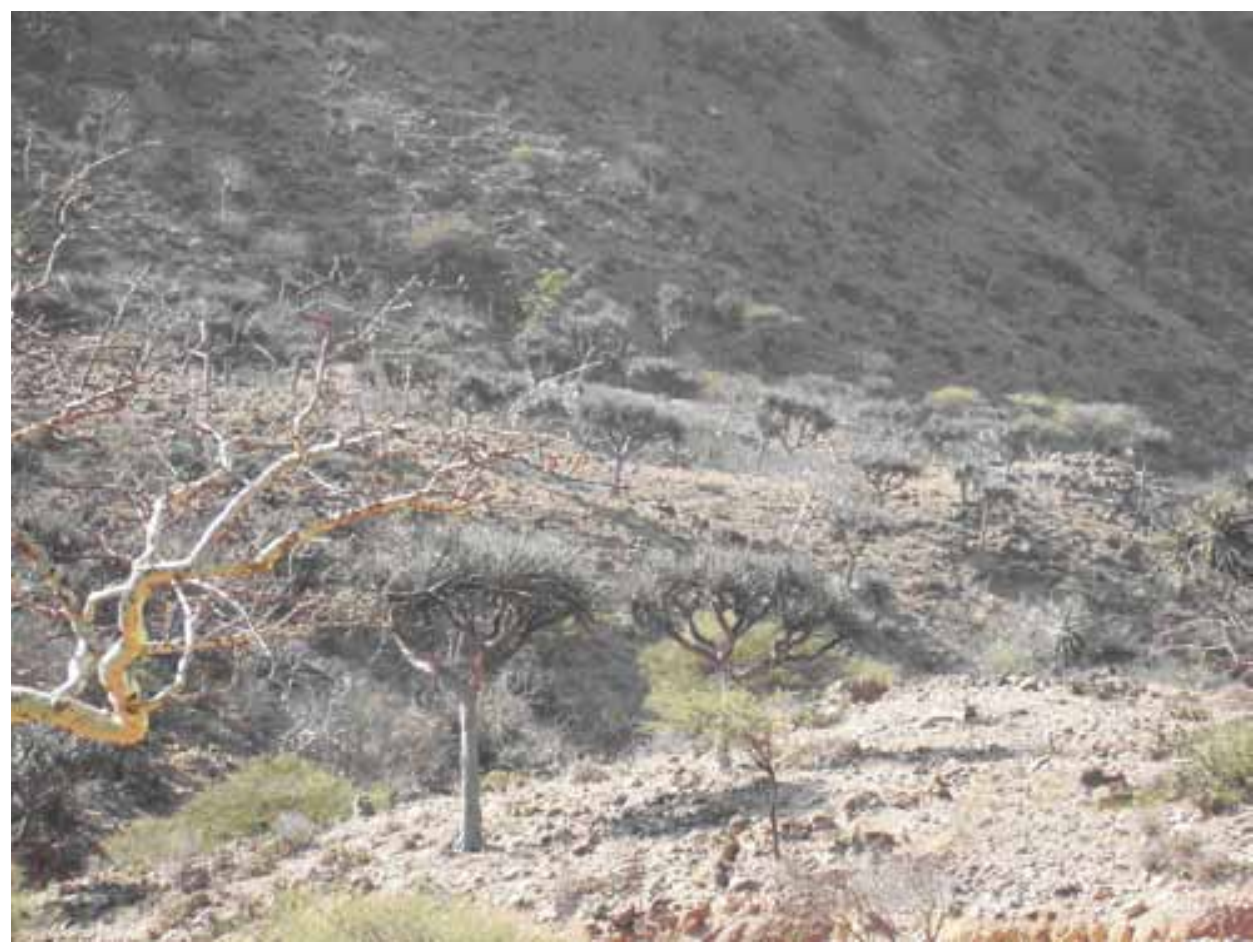

Figure 1.4 Semi-desert vegetation with scattered Commiphora and other species in northeastern Ethiopia (Afar). Photo $\odot$ Lemenih M.

\section{References}

Asfaw, S. 2006 Effects of fire and livestock grazing on woody species composition, structure, soil seed banks and soil carbon in woodlands of North Western Ethiopia. Master's thesis, University of Natural Resources and Applied Life Sciences, Vienna, Austria.

Conservation Strategy of Ethiopia (CSE) 1997 The resources base: its utilisation and planning for sustainability, vol. 1. Environmental Protection Authority and the Ministry of Economic Development and Cooperation, Addis Ababa, Ethiopia.

Eshete, A., Teketay, D. and Hulten, H. 2005 The socio-economic importance and status of populations of Boswellia papyrifera (Del.) Hochst in Northern Ethiopia: the case of North Gondar Zone. Forests, Trees and Livelihoods 5: 55-74.

Ethiopian Forestry Action Program (EFAP) 1994 The challenge for development. Vol II. Ministry of Natural Resources Development and Environmental Protection, Addis Ababa, Ethiopia.

Friis, I. 1992 Forest and forest trees in northeast tropical Africa: their natural habitats and distribution patterns in Ethiopia, Djibouti, and Somalia. HMSO, London. 396p. 
Hawando, T. 1997 Desertification in Ethiopian highlands. RALA Report No. 200. Norwegian Church AID, Addis Ababa, Ethiopia. 162p.

Intergovernmental Panel for Climate Change (IPCC) 2001 Special report on the regional impacts of climate change: an assessment of vulnerability. http:// www.ipcc.ch/ipccreports/sres/regional/index.php?idp=0 [17 January 2011].

Kebede, B. 2006 Land cover/land use changes and assessment of agroforestry practices at Pawe resettlement district, northwestern Ethiopia. Master's thesis, Wondo Genet College of Forestry and Natural Resources, Awassa, Ethiopia.

Kuchar, P. 1995 Identification and characterization of Boresraceae in the southeastern Ethiopia. Southeastern Rangelands Project Technical Paper. Addis Ababa, Ethiopia. 57p.

Lemenih, M. 2005 Production and marketing of gums and gum resins in Ethiopia. In: Chikamai, B. and Casadei, E. (eds) Production and marketing of gum resins: frankincense, myrrh and opoponax, 55-70. NGARA Publication Series 5. Network for Natural Gums and Resins in Africa, Nairobi, Kenya.

Lemenih, M. and Teketay, D. 2004 Natural gum and resin resources: opportunity to integrate production with conservation of biodiversity, control of desertification and adapt to climate change in the drylands of Ethiopia. In: Proceedings of a Workshop on Conservation of Genetic Resources of Non Timber Forest Products (NTFPs) in Ethiopia, 37-49. Addis Ababa, Ethiopia, 5-6 April.

Lemenih, M., Abebe, T. and Olsson, M. 2003 Gum-resins from some Acacia, Boswellia and Commiphora species and their economic contributions in Liban zone, Ethiopia. Journal of Arid Environments 55: 465-482.

Murphy, P.G. and Lugo, A.E. 1986 Ecology of tropical dry forest. Annual Review of Ecology Systematics 17: 67-88.

National Conservation Strategy Secretariat (NCSS) 1993 National conservation strategy, Vol. 1. National policy on the resources base, its utilization and planning for sustainability. Addis Ababa, Ethiopia. 131p.

Ogbazghi, W. 2001 The distribution and regeneration of Boswellia papyrifera (Del.) Hochst in Eritrea. PhD thesis, Wageningen University, Wageningen, The Netherlands.

Roukens, O., Worku, T. and Amare, L. 2005 Gums naturally? Export potential of Ethiopian gums. Export Promotion Department, Addis Ababa, Ethiopia.

Steen, E. 1994 Drylands of the third world: potential for future development (synopsis) Ambio 23: 458-460.

Tadesse, W., Teketay, D., Lemenih M. and Fitwi, G. 2002 Review and synthesis on the state of knowledge of Boswellia species and commercialization of frankincense in the drylands of Eastern Africa. In: Chikamai, B.N. (ed.) Country report for Ethiopia, 11-35. Kenya Forestry Research Institute, Nairobi, Kenya. 
Teketay, D. and Lemenih, M. 2004 Gum and aromatic resin producing trees and shrubs for agroforestry based development of dry lands in Africa. Book abstract. 1st World Congress of Agroforestry, Florida, USA, 27 June-2 July.

United Nations Educational, Scientific and Cultural Organization (UNESCO) 1979 Map of the world distribution of arid regions. UNESCO, Programme on Man and the Biosphere (MAB) Technical Notes 7. Paris.

Woody Biomass Inventory and Strategic Planning Project (WBISPP) 2004 Forest resources of Ethiopia. Ministry of Agriculture, Addis Ababa, Ethiopia.

Worku, A. 2006 Population status and socio-economic importance of gum and resin bearing species in Borana lowlands, southern Ethiopia. Master's thesis, Addis Ababa University, Department of Biology, Addis Ababa, Ethiopia. 


\section{Chapter 2}

\section{Resource base of gums and resins and challenges of productivity}

Mulugeta Lemenih'

\subsection{Introduction}

Several indigenous tree species that grow in Ethiopia's drylands produce diverse and significant quantities of commercial gums and resins. Ethiopia is one of the world's leading producers of incense, notably frankincense (product of Boswellia spp.) and myrrh and myrrh-like resins (products of Commiphora spp.) (Lemenih and Teketay 2003a, b, 2004). Ethiopia also has a large resource base for the production of gum arabic (product of Acacia senegal or A. seyal), although current production levels fall far short of the potential. The production and trade volumes of gums and resins in Ethiopia have been increasing since the 1990s. Between 1998 and 2007, Ethiopia exported about 25192 tonnes - an average of approximately 2519 tonnes per year - of natural gums and resins with a value of 307248000 Eth. Birr (34 138670 USD) (Lemenih and Kassa 2008). The export volume increased on average by $12 \%$ each year from 1998 to 2007. Recognition of the contribution that gums and resins make to local livelihoods and the national economy is growing. For instance, PASDEP's (2005) strong recognition of the subsector's economic role led to plans to double production for the period 2005-2010. Nevertheless, little documentation on the resource base is available in Ethiopia. This chapter summarises the information available on the resource base and identifies factors that threaten its sustainability.

\subsection{Gum- and resin-producing species and their spatial coverage}

\subsubsection{Gum- and resin-producing species}

Ethiopia's diversity of plants that yield commercial gums and resins is one of the highest in the world. About 13 species of Acacia, 16 species of Commiphora and 6 species of Boswellia are known as potential yielders of commercial gums

1 Hawassa University, Wondo Genet College of Forestry and Natural Resources, Shashemene, Ethiopia. 
and resins in Ethiopia (Table 2.1). Among these, gums from 2 species of Acacia and gum resins from 3-4 species of Commiphora and 5 species of Boswellia are currently produced commercially (Table 2.2). Some of the gum- and incenseproducing species are pictured in Figure 2.1. Furthermore, Sterculia setigera (Figure 2.1i), which produces a gum called karaya, is also abundant throughout the country, although gum karaya is not yet under commercial production in Ethiopia.

\subsubsection{Regional distribution and spatial coverage}

Gum- and resin-producing species cover substantial areas of Ethiopia. The country also has vast areas that can be considered potentially suitable for cultivating these tree crops - all the country's arid and semi-arid lands (ASALs),

Table 2.1 Common and potential gums and resins producing Acacia, Commiphora and Boswellia species found in the drylands of Ethiopia

\begin{tabular}{|c|c|c|}
\hline Acacia & Commiphora & Boswellia \\
\hline A. etbaica Schweinf. & C. africana (A.Rich.) Engl. & B. microphylla Chiov. \\
\hline $\begin{array}{l}\text { A. drepanolobium Harms ex } \\
\text { Sjöstedt }\end{array}$ & C. boranensis Vollesen & B. ogadensis Vollesen \\
\hline A. horrida (L.) Willd. & $\begin{array}{l}\text { C. corrugata Gillett and } \\
\text { Vollesen }\end{array}$ & B. neglecta S. Moore \\
\hline A. mellifera (Vahl.) Benth. & C. cyclophylla Chiov & B. rivae Engl. \\
\hline A. oerfota (Forssk.) Schweinf. & C. gileadensis (L.) C. Chr. & B. papyrifera (Del) Hochst. \\
\hline A. polyacantha Willd. & C. guidotti Chiov. & B. pirrotae Chiov. \\
\hline $\begin{array}{l}\text { A. senegal var. senegal } \\
\text { Chivo. }\end{array}$ & C. habessinica (Berg) Engl. & B. sacra Fluckiger ${ }^{\mathrm{a}}$ \\
\hline \multicolumn{3}{|l|}{$\begin{array}{l}\text { A. senegal var. kerensis } \\
\text { Schweinf }\end{array}$} \\
\hline $\begin{array}{l}\text { A. senegal var. leiorhachis } \\
\text { Brenan }\end{array}$ & $\begin{array}{l}\text { C. kua (R. Br. Ex Royle) } \\
\text { Vollesen }\end{array}$ & \\
\hline A. seyal var. fistula Schweinf & C. erythraea (Ehrenb.) Engl. & \\
\hline $\begin{array}{l}\text { A. seyal var. seyal Hochst. Ex } \\
\text { A. Rich }\end{array}$ & C. myrrha (Nees) Engl. & \\
\hline A. sieberiana DC. & C. ogadensis Chiov. & \\
\hline \multirow[t]{4}{*}{ A. stuhlmannii Taub. } & C. rostrata Engl. & \\
\hline & C. schimperi (Berg.) Engl. & \\
\hline & C. serrulata Engl. & \\
\hline & C. truncata Engl. & \\
\hline
\end{tabular}

Source: Lemenih (2005)

${ }^{a}$ This species is reported to exist in Somalia and may exist in the Ogaden area of Ethiopia, although this is yet to be confirmed. 


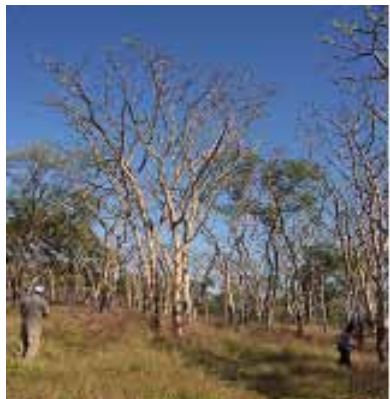

a) B. papyrifera

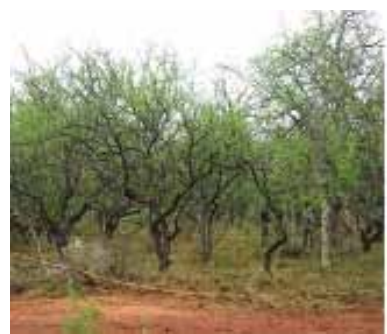

d) B. neglecta

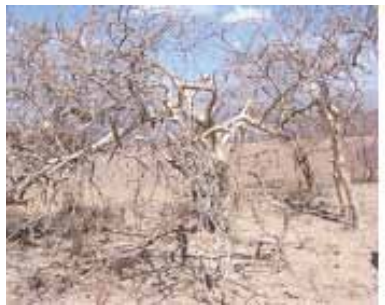

g) C. schimperi

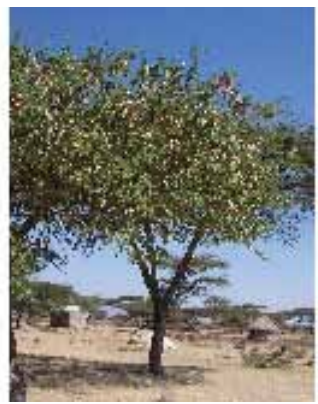

b) A. senegal var. senegal

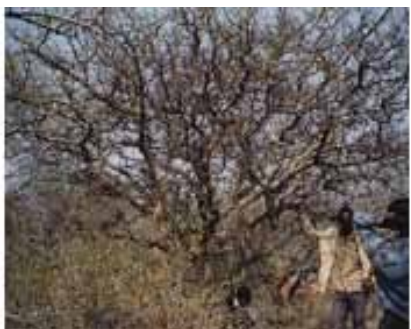

e) C. myrrha

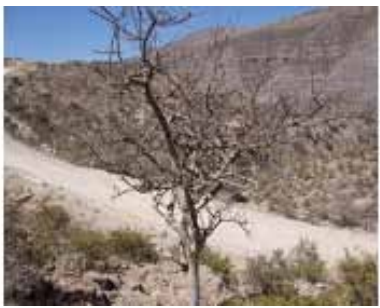

h) C. erythraea

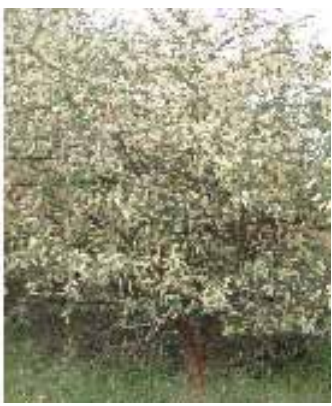

c) A. senegal var. kerensis

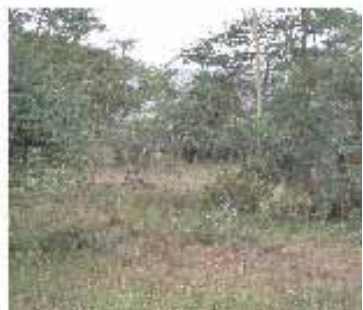

f) A. seyal

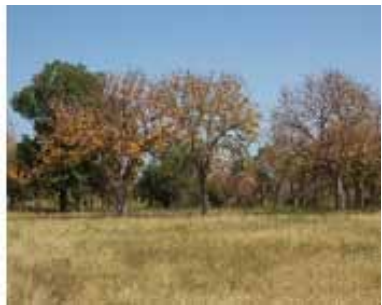

i) Sterculia setigera

Figure 2.1 Some of the gum- and incense-producing species in the woodlands of Ethiopia. Photo $\odot$ M. Lemenih

which cover an area of $560000-615000 \mathrm{~km}^{2}$. Although estimates differ, because of the lack of a national-scale forest inventory, naturally growing Acacia, Boswellia and Commiphora species are believed to predominate across an area of $28550-43350 \mathrm{~km}^{2}$ (Table 2.2). Natural gum-producing species occur virtually all over the low-lying zones in the country's west, south, north, east, central (Rift Valley) areas and in the major river gorges such as the Blue Nile, Tekeze, Genale and Wabi Sheblle Rivers. In terms of regional distribution, gum- and resinproducing species are found in the Afar, Amhara, Benishangul-Gumuz, Gambela, Oromia, Somali, Southern Nations and Nationalities and Tigray Regional States.

\subsubsection{Types of gum and resin products in Ethiopia}

Ethiopia produces a variety of natural gums and resins, which can be classified as either aromatic or non-aromatic (Table 2.3). The former category comprises 
odoriferous gums and resins such as frankincense (gum olibanum), myrrh and opoponax, and the latter consists of gum arabic and other odourless gums and resins.

Table 2.2 Estimated extent of area containing vegetation with gum- and resinproducing species in Ethiopia by regional state

\begin{tabular}{llr}
\hline Regional state & Genus & Estimated area (ha) \\
\hline Afar & Commiphora, Acacia & 65000 \\
Amhara & Boswellia, Commiphora, Acacia, Sterculia & 680000 \\
Benishangul & Boswellia, Acacia, Sterculia & 100000 \\
Gambela & Commiphora, Acacia, Sterculia & 420000 \\
Oromia & Boswellia, Commiphora, Acacia, Sterculia & 430000 \\
SNNP & Boswellia, Sterculia, Acacia & 70000 \\
Somali & Boswellia, Sterculia, Commiphora, Acacia & $150000-1500000$ \\
Tigray & Boswellia, Sterculia, Commiphora, Acacia & 940000 \\
Total & & $\mathbf{2 8 5 5 0 0 0 - 4 3 5 5 0 0 0}$ \\
\hline
\end{tabular}

Source: Fitwi (2000), Lemenih et al. (2003)

Table 2.3 Commercial gums and resins with botanical sources and local designations

\begin{tabular}{|c|c|c|c|}
\hline Category & Common name & Botanical source & $\begin{array}{l}\text { Local } \\
\text { designation }\end{array}$ \\
\hline \multirow[t]{8}{*}{ Aromatic gums/resins } & & B. papyrifera & Tigray type \\
\hline & \multirow{4}{*}{$\begin{array}{l}\text { Frankincense / } \\
\text { Gum olibanum }\end{array}$} & B. neglecta & Borana type $^{a b}$ \\
\hline & & B. rivae & \\
\hline & & B. microphylla & Ogaden type ${ }^{b}$ \\
\hline & & B. ogadensis ${ }^{a}$ & \\
\hline & True myrrh & C. myrrha & Myrrh \\
\hline & Opoponax & C. guidotti & Opoponax \\
\hline & Hagar & $\begin{array}{l}\text { C. erythraea/ } \\
\text { C. africana/others }\end{array}$ & Hagar \\
\hline \multirow{2}{*}{$\begin{array}{l}\text { Non-aromatic gums/ } \\
\text { resins (gum arabic) }\end{array}$} & True Arabic gum & A. senegal & \\
\hline & Gum talha & A. seyal & \\
\hline
\end{tabular}

a Although this species' existence is cited in some references, it remains in doubt (Girmay Fitwi, personal communication).

b The precise source species for these 2 olibanum classes are not well known. However, gum resin from Boswellia, true myrrh, opoponax and hagar are collectively referred to as gum myrrh, whereas products from B. neglecta, B. rivae, B. microphylla and B. ogadensis are often collected and traded mixed. 


\subsubsection{Aromatic gums and resins}

Aromatic gums and resins are hardened, resinous, exudates obtained from trees of certain Boswellia and Commiphora species. Gum olibanum (frankincense), myrrh and opoponax belong to this group.

i) Frankincense. In the literature, the terms frankincense, incense, gum olibanum, olibanum, resin and aromatic products are all used to refer to the products of Boswellia trees. Frankincense refers to the dried, gummy exudates obtained from various species of the family Burseraceae and the genus Boswellia.

Three types of frankincense are distinguished in Ethiopia according to their origin: Tigray type, Ogaden type and Borana type (Table 2.2). Tigray type olibanum is the most widely traded on both domestic and international markets (Figure 2.2a). This is the gum resin obtained from the species Boswellia papyrifera (Del.) Hochst, which occurs in the northern, northwestern and northeastern lowlands of Ethiopia as well as in the river gorges of Abay and Tekeze. Ogaden and Borana types are gum resins produced from Boswellia species found in the dry forests of the eastern and southeastern lowlands. The specific source species for these latter types of frankincense are not clear. However, gum resins from B. rivae (Engl.), B. ogadensis (Vollesen), B. neglecta (S. moore) and B. microphylla (Chior.) are collected from these areas and traded as frankincense (Fitwi 2000, Lemenih et al. 2003). Other species that yield resinous products designated as frankincense may also exist in these parts of Ethiopia, and may even include species known from Somalia, such as B. sacra (Vollesen 1989). The southeastern Acacia-Commiphora woodlands are the country's richest in terms of diversity of Boswellia species.

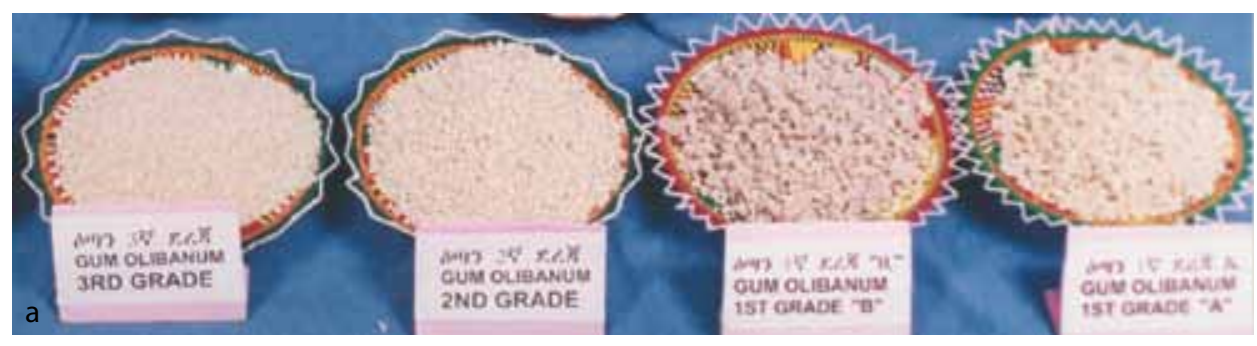

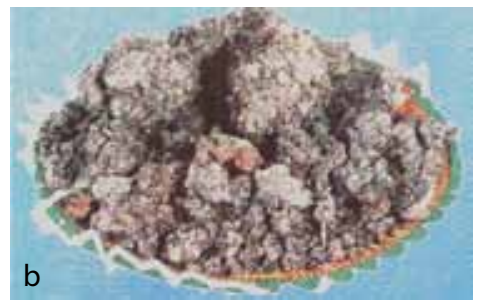

Figure 2.2 (a) White Tigray type frankincense of various grades obtained from B. papyrifera, and (b) black Borana incense obtained from B. neglecta. Photo $\odot$ Courtesy NGPME (http://naturalgum. diytrade.com) 
ii. Commiphora gum resins. The diversity of Commiphora species in Ethiopia is one of the highest in the world. Fifty-two species of Commiphora are known to exist in the country, 14 of which are endemic (Vollesen 1989). The southeastern Acacia-Commiphora woodlands have the richest diversity of Commiphora species, with 35 (67\%) of the Commiphora species found in the country recorded there, including 9 (64\%) endemic species (Vollesen 1989, Kuchar 1995).

The major Commiphora gums of economic importance in Ethiopia are myrrh, opoponax and hagar. The names myrrh, bdellium or opoponax are often used interchangeably to refer to the various resinous products obtained from Commiphora species. However, in some literature, the products are distinguished based on botanical source. For instance, Thulin and Claeson (1991) classify Commiphora gum resins into scented/perfumery myrrh called 'bissabol' or opoponax and medicinal myrrh called 'heerabol'. Gum myrrh (heerabol) is a typical name for the gum obtained from C. myrrha (Nees) Engl., which is called true myrrh (FAO 1995; Figure 2.3a). This myrrh is used mainly for medicinal purposes (Lemenih and Teketay 2003b). Opoponax or scented myrrh (Figure $2.3 \mathrm{~b}$ ) is the name given to the myrrh obtained from C. guidotti Chior (Thulin and Claeson 1991, Farah 1994) and from C. kataf (FAO 1995).
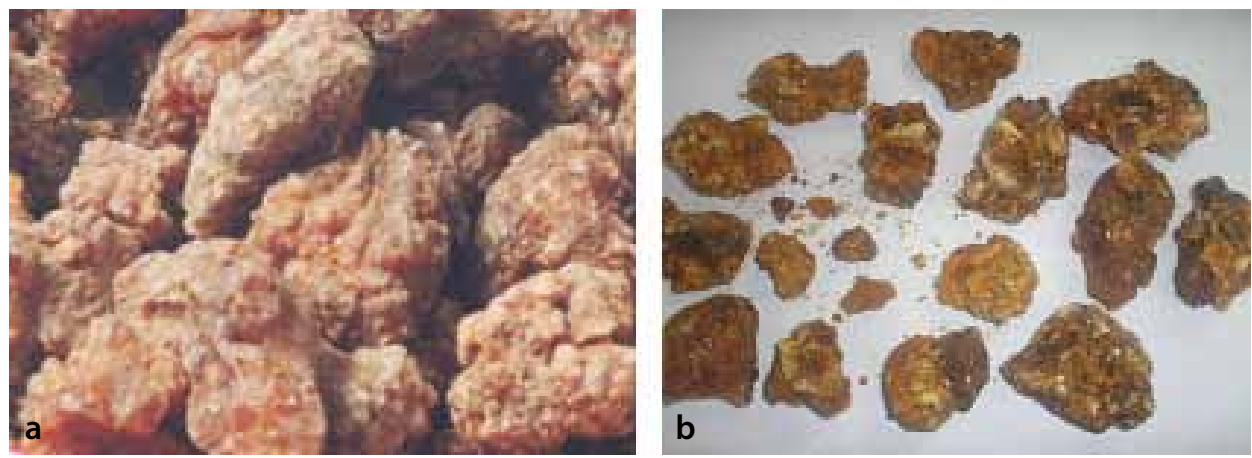

Figure 2.3 (a) True myrrh from C. myrrha and (b) opoponax from C. guidotti species. Photo $\odot$ G. Fitwi G

The resin from C. africana (A. Rich.) and C. erythraea (Ehrenb.) Engl., locally called 'hagar', is traded widely across borders in the south and southeastern parts of Ethiopia (Lemenih et al. 2003). Hagar has chiefly medicinal applications, serving as a laxative, and performs insecticidal and anti-parasitic (anti-tick) functions in traditional livestock husbandry. Many other Commiphora species in Ethiopia produce gums also collected and sold under the name myrrh or opoponax; these include C. boranensis Vollesen, Engl., C. habessinica (Berg.) Engl. and C. corrugata Gillett and Vollesen (Tucker 1986, Lemenih et al. 2003). 
Gum resins from these species are generally sold mixed with resins of commercially known species.

\subsubsection{Non-aromatic gums}

The mainly odourless and/or tasteless products in this category include gum arabic and gums such as gum karaya from Sterculia setigera.

i. Gum arabic. Broadly defined, gum arabic is a dried exudate collected from several Acacia species, and hence is sometimes referred to as 'gum Acacia'. However, international commercial specifications identify gum arabic as a dried exudate obtained from the stems and branches of A. senegal (L) Willdenow or A. seyal (Fam. Leguminosae) (FAO 1998). In Ethiopia, gum arabic in most reports refers to the gum collected from $A$. senegal or $A$. seyal (although the 2 types are clearly collected and delivered separately), with some literature referring to them as gum arabic and gum talha, respectively. True gum arabic is collected from 2 varieties of $A$. senegal in Ethiopia: A. senegal var. kerensis and $A$. senegal var. senegal (Figure 2.4). Good stocks of $A$. senegal and $A$. seyal are found in the western, central (Rift Valley), southern and southeastern lowlands of Ethiopia.
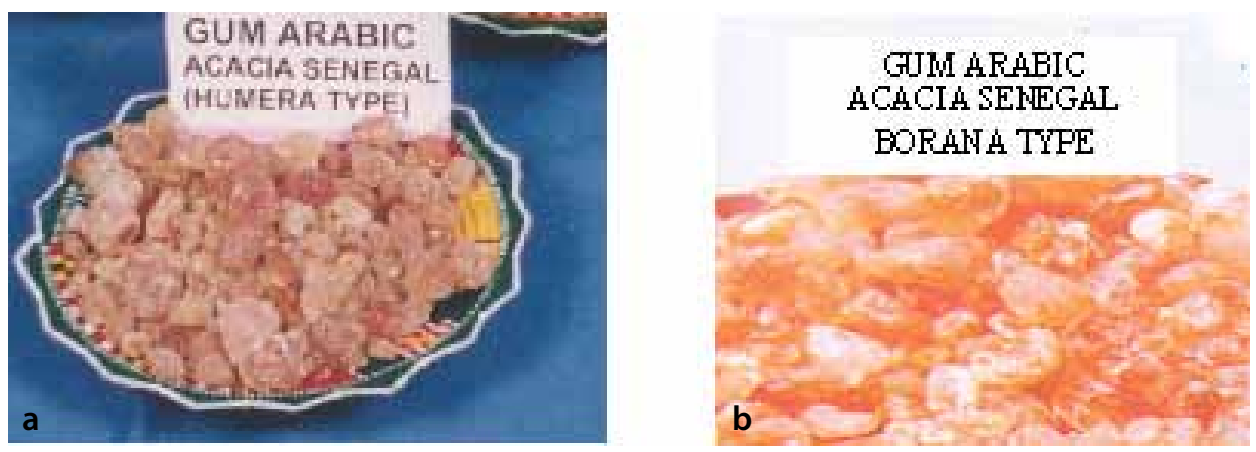

Figure 2.4. (a) Gum arabic from $A$. senegal var. senegal and (b) var. kerensis. Photo $\odot$ Courtesy of NGPME (http://naturalgum.diytrade.com) and M. Lemenih

ii. Gum karaya. Gum karaya is obtained from Sterculia species (Fitwi 2000), several of which grow in northern and northwestern Ethiopia, although it is widely represented by $S$. setigera. Despite its potential, no actual production or marketing of this product has been reported.

\subsubsection{Density and regeneration status}

Regeneration is a central component of tropical dry forest ecosystem dynamics and restoration. Sustainable forest use is only possible if adequate regeneration occurs. Most of the species in the dry forests of Ethiopia regenerate via one or more means such as seeds, whether from seed rain (recently dispersed seeds) 
or soil seed banks (dormant seeds in the soil), seedling banks (established, suppressed seedlings in the understorey) and/or vegetative means (coppice and/ or root sprouts) (Teketay 1997, Tesfaye et al. 2002, Tesfaye 2008). However, the regeneration profiles of most species in the dry forests of Ethiopia are generally poor because of the open access nature of the forests, despite variations according to geographical location, vegetation formation, species type and the degree of disturbance. Human-related disturbances, such as forest grazing, forest fire and intensive removal of trees for timber, construction and fuel, have a significant negative impact on regeneration of the species. The regeneration profiles of most species also vary in response to environmental variables, such as altitude, slope and edaphic conditions. Within the same plant community, some species may show a healthy regeneration and population structure, whereas others exhibit critical natural regeneration problems. Boswellia papyrifera in the CombretumTerminalia deciduous woodlands is an example of a poorly regenerating species (Eshete et al. 2005, Ogbazghi et al. 2006, Rijkers et al. 2006, Lemenih et al. 2007). The major population obstacle for this species is not seedling emergence but the high mortality of seedlings (Negussie et al. 2008). Even when protected against grazing and fire, the seedlings fail to exhibit good survival (Asfaw 2006, Negussie et al. 2008). Following are syntheses of available information for some major gum-producing species and regions.

\subsubsection{The case of the Central Rift Valley}

Ethiopia's Central Rift Valley holds great potential for gum arabic production from $A$. senegal and $A$. seyal species, which occur in the area in association with a few other species, primarily Balanites aegyptiaca, A. tortilis, A. etbaica, M. senegalensis, Ziziphus mucronata and Dichrostachys cinerea. The total woody plant density across various land use/land cover systems in the area ranges between 268 and 1584 stems/ha. The density of the gum-producing species A. senegal and A. seyal is within the range of 31-947 stems/ha. Acacia senegal depicts normal population structures in the Central Rift Valley, showing good regeneration and stable population (Figure 2.5). Furthermore, humanrelated disturbance, when modest, is found to encourage regeneration of both species (Figure 2.5b), which is a typical feature of some dryland woody species (Yebeyen 2006).

\subsubsection{The case of Metema (northwestern lowlands)}

In the western, northern and northwestern lowlands of Ethiopia, the principal gum- and resin-producing species is B. papyrifera. For example, in Metema district, $B$. papyrifera on average accounts for $51 \%$ of the woody plant density (Eshete 2002), although variations occur from site to site as a function of local edaphic, climatic and anthropogenic factors. A similar population structure for B. papyrifera has been reported in Eritrea (Ogbazghi 2001, Ogbazghi et al. 2006, Rijkers et al. 2006) and Tigray, Ethiopia (Gebrehiwot 2003, Gebrehiwot 

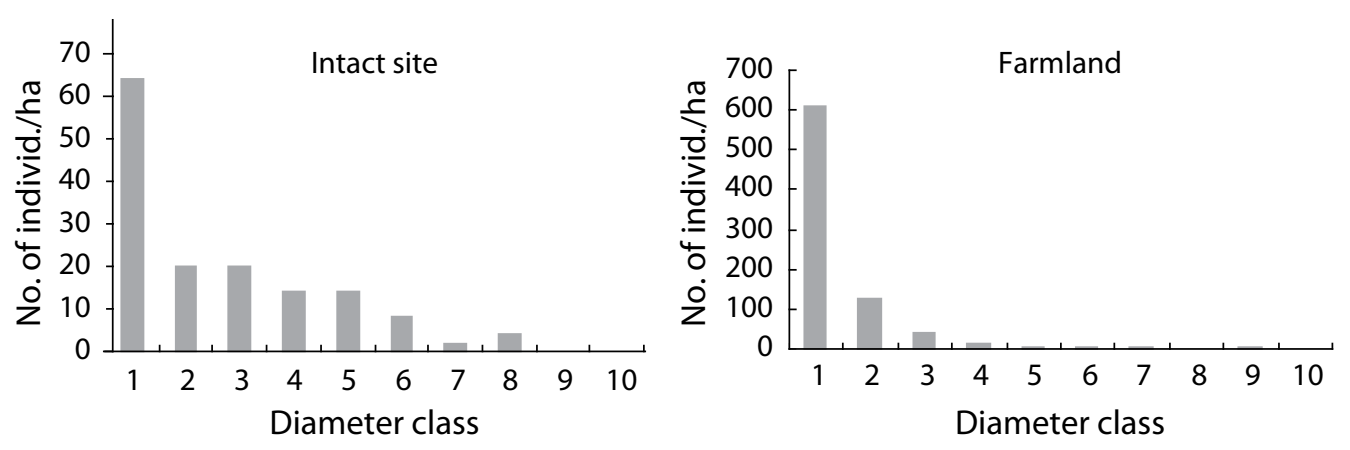

Figure 2.5. Population structure of $A$. senegal at 2 contrasting sites in Central Rift Valley of Ethiopia: (a) protected and (b) farmland Source: Yebeyen (2006)

et al. 2002). The density of B. papyrifera in the Metema area ranges from 64 to 225 stems/ha, similar to reports from Tigray (Gebrehiwot 2003) and Eritrea (Ogbazghi 2001).

The population structure of $B$. papyrifera shows the presence of a large proportion of individuals in the medium diameter classes, and few individuals in the smaller (seedling and sapling) diameter classes. Great contrasts are evident in the population structure of the species in different seasons (rainy season vs dry season) (Figure 2.6). These contrasting structures demonstrate that although a
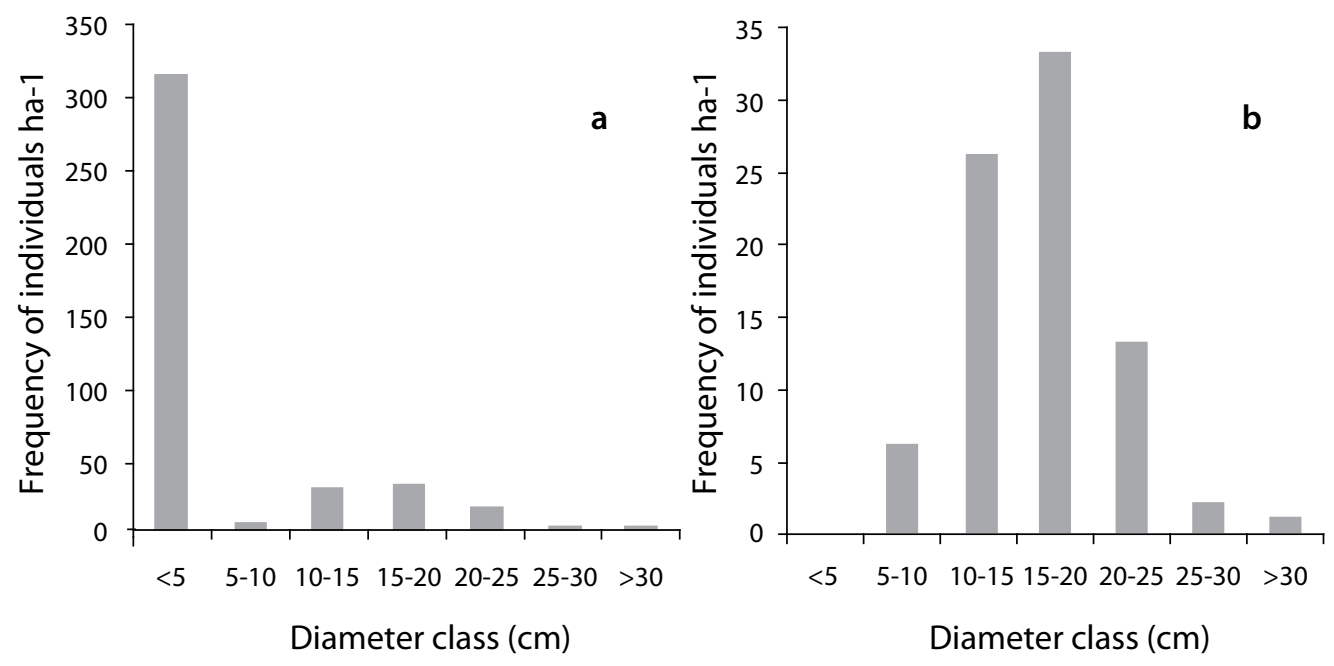

Figure 2.6 Population structure of B. papyrifera species in Metema, Ethiopia: (a) during the rainy season and (b) during the dry season 
large number of seedlings emerge during summer, almost none survive the dry season to grow to sapling and adult individuals. This high seedling mortality is a major obstacle for this species and is currently threatening the population. Different studies have revealed that even when protected against grazing and fire, the seedlings fail to exhibit good survival (Asfaw 2006, Negussie et al. 2008).

\subsubsection{The case of Borana (southern lowlands)}

Ethiopia's southern lowland woodlands are characterised by a higher diversity of gum- and resin-producing species than other woodland areas in the country. For instance, in Liban district, 8 species in the genera Acacia, Boswellia and Commiphora that provide currently traded gums and resins have been identified (Lemenih et al. 2003). Similarly, in Borana district, 15 woody species have been recorded: 9 from the genus Commiphora, 3 from the genus Boswellia and 3 from Acacia (Table 2.4).

The density of gum- and resin-producing species in the southern lowlands ranges between 562 and 1742 stems/ha. These species account for $43-83 \%$ of

Table 2.4 Gum- and incense-producing tree species found in the Borana area

\begin{tabular}{lll}
\hline Scientific name & Family & Product \\
\hline Acacia seyal & Fabaceae & Gum arabic \\
Acacia senegal & Fabaceae & Gum arabic \\
Acacia mellifera & Fabaceae & Gum arabic \\
Boswellia neglecta & Burseraceae & Incense \\
Boswellia microphylla & Burseraceae & Incense \\
Boswellia rivae & Burseraceae & Incense \\
Commiphora africana & Burseraceae & Hagar \\
Commiphora baluensis & Burseraceae & Myrrh \\
Commiphora confuse & Burseraceae & Myrrh \\
Commiphora myrrha & Burseraceae & Myrrh \\
Commiphora habessinica & Burseraceae & Myrrh \\
Commiphora kua & Burseraceae & Myrrh \\
Commiphora terebinthina & Burseraceae & Myrrh \\
Commiphora boranensis & Burseraceae & Myrrh \\
Commiphora schimperi & Burseraceae & Myrrh \\
\hline
\end{tabular}

Source: Worku (2006)

a Gum from A. mellifera is not recognised as gum arabic according to international designations. Products collected from this species are commonly sold mixed with true gum arabic of $A$. senegal and A. seyal origins. 


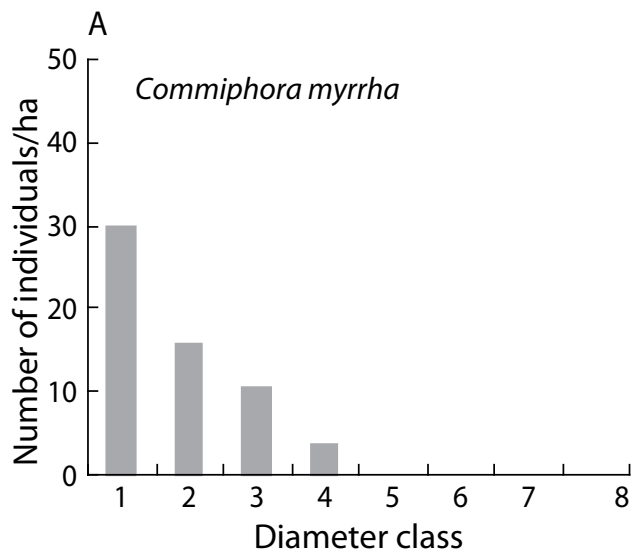

B
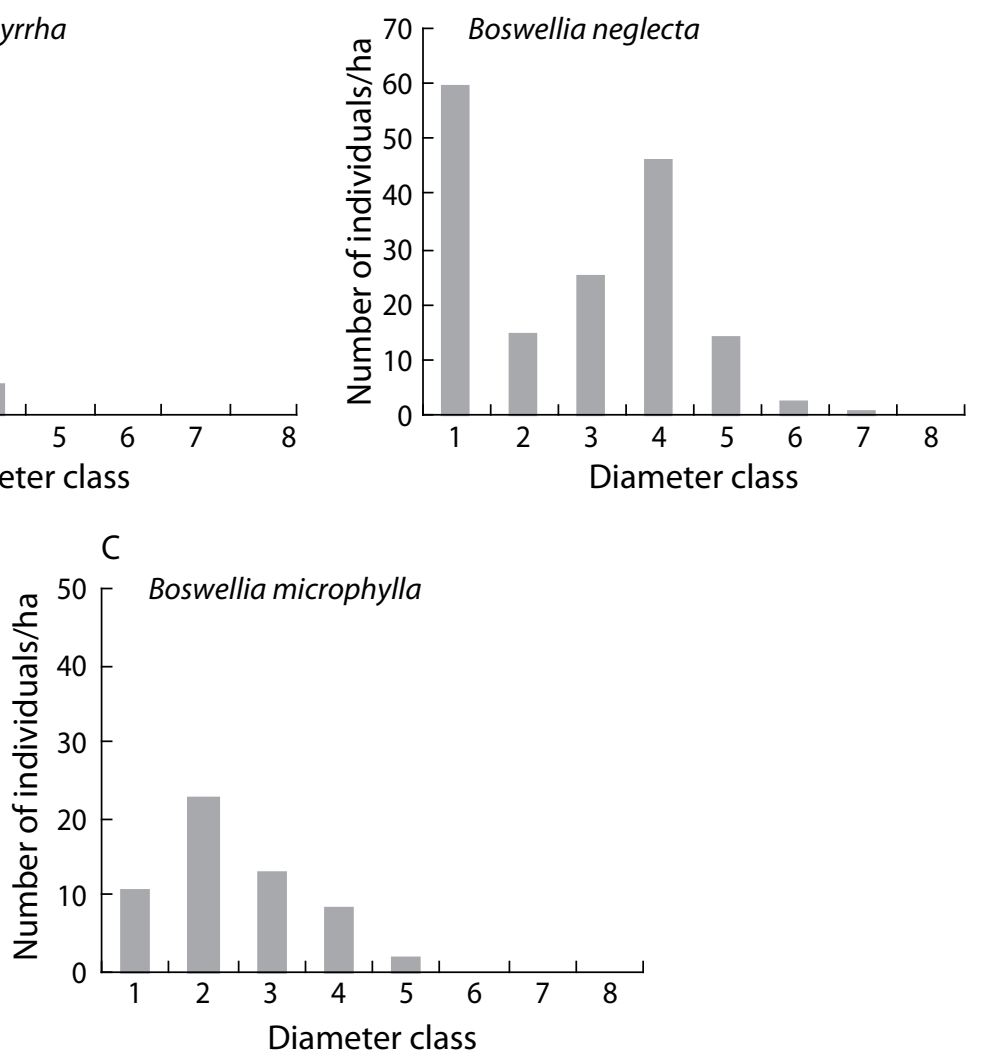

Figure 2.7 Diameter class distribution of 3 gum- and resin-producing species in Borana showing impacts of human disturbances on population structure (diameter classes in cm: $1=\leq 4 \mathrm{~cm} ; 2=4-8 ; 3=8-12 ; 4=12-16 ; 5=16-20 ; 6=20-24 ; 6=24-28$; $7=28-32 ; 8=32-34 ; 9=34-38$ )

Source: Worku (2006)

the total stem density in the woodlands (Lemenih et al. 2003, Worku 2006). The population structure for gum- and resin-yielding species varies (Figure 2.7).

Some species show an inverted 'J' shape distribution, e.g. C. myrrha (Figure 2.7a), which indicates a normal and stable population. However, for most of the species, including C. kua, B. neglecta, B. microphylla, C. habessinica, C. boranensis, $C$. terebinthina, C. baluensis, C. confusa and B. rivae (e.g. Figure $2.7 \mathrm{~b}$ and c), the population structure deviates from this inverted J-shaped pattern, possibly indicating the effects of human-induced disturbances on the species' regeneration ecology (Worku 2006). 


\subsection{Yield and productivity}

\subsubsection{Yield at tree level}

Reliable and rigorous data on annual yields of gums and resins per tree and/or area in Ethiopia are scarce. Few scientific studies have been conducted on these aspects, and thus it is near impossible to provide reliable information. Most yield statistics for different products from different geographical regions are expert guesses, and should be treated with due caution. Yield variations are expected between species, varieties, size and age classes and across different geographical regions. Similarly, climatic conditions, edaphic characteristics and genetic differences are all expected to cause variations in yield between the same species located in different geographical regions. For B. papyrifera in the Metema district, Tadesse et al. (2004) reported an annual yield of 6.7-451.4 g per tree, and Eshete and Asmamaw (unpubl.) reported an annual yield of 207-352 g per tree in the Metema district. These variations in incense yield are attributed to tree size and tapping intensity. Generally, trees with a bigger diameter at breast height (DBH) yield more incense than trees with a smaller DBH. Similarly, increased tapping intensity increases incense yield per tree, although this has also been shown to affect tree vitality and reproductive biology. Incense yield can be doubled or even tripled by increasing the number of tapping spots per tree from 4 to 12 . However, it is recommended that smaller trees be wounded in only a few spots, with the number of wounds increasing as the tree grows in diameter/size. Trees in more arid environments also yield more incense than trees in wetter environments. Other estimates for olibanum and myrrh show yields in the range of $0.07-1.0 \mathrm{~kg}$ per tree per year, with the average being $0.50 \mathrm{~kg}$ (Fitwi 2000), whereas another report provides an estimate as high as $3.0 \mathrm{~kg}$ per tree per year (Gebremedhin 1997). Yield of arabic gum is estimated to be $0.25 \mathrm{~kg}$ per tree each season, which is often considered to be the average yield (Coppen 1995).

\subsubsection{Potential and actual annual production levels at national scale}

Reliable information is lacking on the potential and actual production levels of gums and resins at the national scale in Ethiopia. Reasons for the lack of information are: (1) poor documentation by purchasing firms and producers; (2) lack of proper forest management and accountable forest product control offices that are responsible for quantifying and/or controlling the production processes; (3) open access harvest and uncontrolled trade of forest products, particularly gums and resins in different parts of the country; and (4) uncontrolled trade across borders with neighbouring countries as well as between enterprises in the country. Reasonable estimates for potential production of the various gum and resin products based on stand density and spatial coverage are given in Table 2.5. With regard to actual production, fairly 
Table 2.5 Estimated potential and annual production of gum and incense in Ethiopia

\begin{tabular}{lrrr}
\hline Type of product & $\begin{array}{c}\text { Estimated area } \\
(\mathrm{ha})^{\mathrm{a}}\end{array}$ & $\begin{array}{c}\text { Estimated annual production } \\
\text { (tonnes) }^{\mathrm{b}}\end{array}$ \\
\hline Gum olibanum & 2284000 & 57100 & \\
Gum arabic & 399700 & 4996 & (A. senegal 52\%, A. seyal 48\%) \\
Gum Commiphora & 171300 & 8565 & (myrrh 88\%, opoponax 12\%) \\
Total & 2855000 & 70661 & \\
\hline
\end{tabular}

Source: a Fitwi 2000; b Calculated based on 50 trees per ha and yields of $0.5,0.25$ and $1 \mathrm{~kg}$ per trees for gum olibanum, gum arabic and gum Commiphora, respectively, as well as the share calculated from 10-year production data for each type

Table 2.6 Natural gums (gum olibanum, gum arabic, myrrh/opoponax) exported from Ethiopia by various enterprises, 1995-2010

\begin{tabular}{lccc}
\hline Year & $\begin{array}{c}\text { Total production } \\
\text { (tonnes) }\end{array}$ & $\begin{array}{c}\text { Export quantity } \\
\text { (tonnes) }\end{array}$ & $\begin{array}{c}\text { Value of export sale } \\
\text { (USD) }\end{array}$ \\
\hline $1992 / 1993$ & 2671 & 354 & 3138000 \\
$1993 / 1994$ & 3421 & 755 & 7418000 \\
$1994 / 1995$ & 5303 & 987 & 7672000 \\
$1995 / 1996$ & 4557 & 389 & 3738000 \\
$1996 / 1997$ & 2522 & 710 & 5660000 \\
$1997 / 1998$ & 3606 & 1925 & 2411263 \\
$1998 / 1999$ & 4934 & 1663 & 1990947 \\
$1999 / 2000$ & 4608 & 1648 & 2264737 \\
$2000 / 2001$ & 4532 & 2183 & 2764737 \\
$2001 / 2002$ & 4427 & 2138 & 2712526 \\
$2002 / 2003$ & 4778 & 1544 & 2014737 \\
$2003 / 2004$ & 7479 & 3109 & 4001053 \\
$2004 / 2005$ & 4906 & 3791 & 4529474 \\
$2005 / 2006$ & 2894 & 3529 & 4911368 \\
$2006 / 2007$ & 1474 & 3976 & 5293158 \\
$2007 / 2008$ & 1544 & 3834 & 5201368 \\
Average & 3979 & 2033 & 4107586 \\
\hline
\end{tabular}

Source: Compiled from data collected from companies, the Ethiopian export promotion agency and the Ethiopian customs authority

good estimates can be obtained by gathering scattered statistics from various sources. Proper records exist for trade, specifically export trade, which may thus provide reasonably reliable statistics. 
Estimates for actual production and export volumes for the past decade, as obtained from various sources, are presented in Table 2.6. The data show that Ethiopia has exported on average 2033 tonnes of gums and resins to the world market each year during the past 15 years. However, the problem with export statistics is the aggregation of all products (frankincense, myrrh, opoponax, balsam, etc.) into a single commodity. This makes it difficult to provide separate statistics for individual gum and resin products.

Supplies to domestic markets are hard to quantify. Domestic consumption is mainly for household uses such as fumigation during coffee ceremonies, chat chewing, dispelling of bad smells and use in religious rituals; hence, rough estimates can be provided based on findings from surveys of households and religious institutions. Lower grades (Grades 4 and 5) of Tigray type olibanum and myrrh, and all Borana and Ogaden type olibanum, almost always end up in the domestic market. A household consumes about 5-10 g of incense per day, mainly during the coffee ceremony. The average annual consumption for this purpose is thus estimated at 4500 tonnes. Similarly, about 6000 tonnes of incense is consumed annually in connection with religious ceremonies, putting the average annual domestic consumption at 10500 tonnes. The domestic market consumes almost all of Grades 4 and above of the Tigray type olibanum and nearly all of the Borana and Ogaden type incenses.

Table 2.7 Comparison of actual and potential gum and resin production in Ethiopia, based on figures for 2003/04

\begin{tabular}{lcccc}
\hline $\begin{array}{l}\text { Regional } \\
\text { state }\end{array}$ & $\begin{array}{c}\text { Estimated actual } \\
\text { production }\end{array}$ & $\begin{array}{c}\text { Share of total } \\
\text { annual } \\
\text { production }\end{array}$ & $\begin{array}{c}\text { Estimated } \\
\text { potential } \\
\text { production }\end{array}$ & $\begin{array}{c}\text { Share of actual } \\
\text { production of } \\
\text { estimated } \\
\text { potential } \\
\text { (in tonnes) }\end{array}$ \\
\hline Tigray & 4993 & $(\%)$ & (in tonnes) & ( \\
Amhara & 2396 & 62 & 30433 & 16 \\
Benishangul & 316 & 30 & 16545 & 14 \\
Oromia & 130 & 4 & 2500 & 13 \\
Somalia & 185 & 2 & 4031 & 3 \\
Others & - & 2 & 4106 & 5 \\
Total & $\mathbf{8 0 2 0}$ & - & 13042 & - \\
\hline
\end{tabular}

Source: a MOARD for 2003/04; b see Table 2.6. 
Comparison of actual and potential production levels in the various regions shows that the present supply falls far short of the potential (Table 2.7). For instance, Tigray Regional State, which is the largest producer of gum resin in the country, produces less than a quarter of its potential. As shown in Table 2.7, gum olibanum from B. papyrifera in Tigray Regional State contributes almost twothirds $(62 \%)$ of the total annual production. It also provides the bulk of exports (Lemenih 2005).

\subsection{Economic and ecological significance}

\subsubsection{Economic significance}

\subsubsection{Contribution to the national economy}

An important benefit of gums and resins is that they generate foreign currency earnings gained through exports. Ethiopia, as a developing country, has few items to export, and gums and gum resins are among the few products from the country's forestry sector with export value. As shown in Table 2.6, Ethiopia exported 29340 tonnes of natural gums and resins during the 10 years from 1997/98 to 2007/08, generating about 38 million USD worth in foreign currency. This is equivalent to average annual earnings of about 3.5 million USD (32.8 million Eth Birr). This value does not include the large but unregistered parallel trade across borders with neighbouring countries. Despite declining trends in production volumes, the export quantity and the value of foreign currency that the country is earning from the gums and resins subsector have been increasing in the past decade. This is probably due to the increasing participation of private enterprises in the production, processing and exporting of natural gums as they take advantage of the Ethiopian government's recent policy reforms and export promotion support.

The subsector also makes a relatively high economic contribution through domestic markets. Based on current prices of an average of 10 Birr per kg, the domestic market's annual turnover is estimated at 100.5 million Eth Birr (11.7 million USD). Combined with export earnings, therefore, the total annual turnover from the subsector is equivalent to about 133 million Eth Birr (15.5 million USD). However, gums and resins could contribute more to the national economy if the full potential of the subsector were exploited. Based on 
current prices, the potential yield equivalent of 70660 tonnes/year could generate annual revenues of about 757 million Eth Birr (88 million USD).

\subsubsection{Contribution to the local economy}

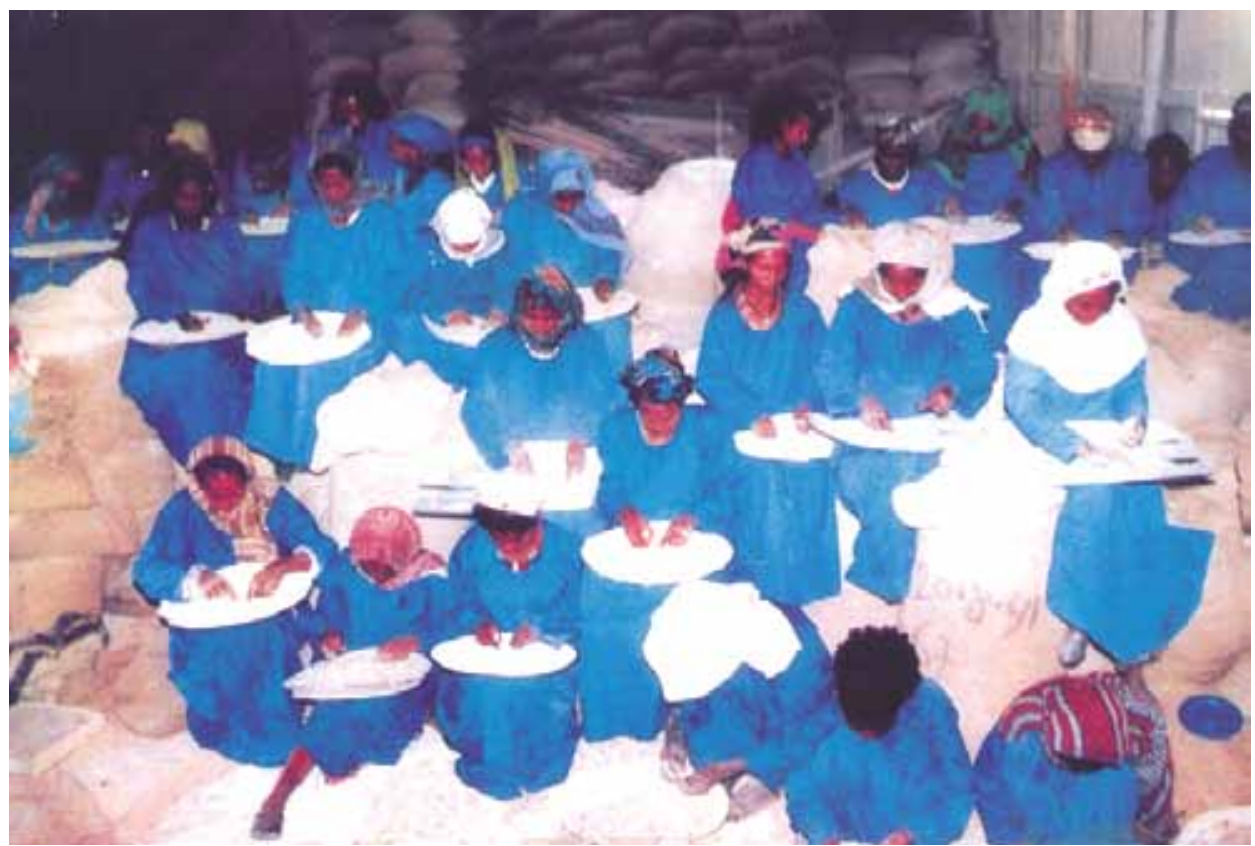

Figure 2.8 Women sorting and grading gums and resins

Photo $\odot$ Courtesy of NGPME (http://naturalgum.diytrade.com)

The gums and resins subsector also contributes to the local economy and to rural livelihoods. Women in particular benefit from the processing and retailing of gums and resins. The subsector contributes to the local economy in terms of employment, income diversification, emergency food supply and direct support of other economic sectors, principally livestock production.

i. Employment. The lack of modern production and processing technology means that gums and resins are collected, cleaned, sorted and graded using traditional, labour-intensive processes (Figure 2.8).

Along the production and marketing chains, the gums and resins business is estimated to employ about $25000-35000$ people annually at the national level. Money earned by tappers and collectors varies from year to year and place to place, but tends to be within the ranges of 165-300 Birr for Tigray type, 150-285 for Borana type, 500-600 for Ogaden type, 225-800 for gum arabic, 1300-1800 for myrrh and 600-700 for opoponax. Graders earn about 7 Birr per kg, with payment based on the grades. 
ii. Income diversification. Gum and resin products are an important source of income for households in producing areas. In some cases, gums and resins are the only source of household income, whereas in others they function as a safety net (Lemenih et al. 2003, Worku 2006). For instance, a study in the southeastern lowlands of Liban showed that income from the collection and sale of oleo-gum resin is the second most important means of household livelihoods (Lemenih et al. 2003). The economic incentives provided by gums and resins have wider implications in the overall socio-economic conditions of households living in arid and semi-arid lowlands. Diversification of economic activities could potentially minimise the risks associated with the frequent crop and fodder failures that result from the recurring droughts. In particular, in the dryland areas where the economic activities of pastoralists and agro-pastoralists cannot produce sufficient food for families' basic subsistence, collection of gums and resins may be important for supplementing household income and livelihoods. Forest income tends to be important more for its timing than its magnitude. One advantage associated with gum and resin collection in this regard is their availability during the dry season when forage and grains are scarce (Lemenih et al. 2003); thus they provide an alternative source of income during the dry season.

iii. Contribution to livestock production. Gum- and resin-producing trees also contribute to household food security by supporting other economic sectors, principally livestock production. Livestock production, which is the mainstay of the agro-pastoral and pastoral economy, is heavily dependent on fodder supplied from the woody plant biomass (Kuchar 1995). Particularly in the dry season and during droughts, trees and shrubs comprise the only source of fodder for livestock. The Burseraceae and Mimosaceae families in particular provide nutritious fodder, and virtually all plants in the 2 families are palatable to livestock (Kuchar 1988, Farah 1994). During prolonged drought periods, perennial woody vegetation supplies more fodder than annual grasses, which makes it more useful in dryland regions. The pastoral and agropastoral communities' priority is to use the vegetation resources for grazing (Lemenih et al. 2003).

iv. Other local uses of economic importance. Gums and resins also have significant socio-economic and cultural values (Table 2.8). Some gums and resins are used as emergency food during periods of famine. Others are smoked in houses and during cultural and divine worships to stimulate deep spiritual meditation. Several gum resins, including frankincense and myrrh, are widely used as herbal medicines, insecticides and hygienic and sanitation detergents. 
Table 2.8. Local uses of gums and resins and their source species in lowland areas of Ethiopia ('-' denotes not applicable; '+' denotes applicable)

\begin{tabular}{lcccc}
\hline Species & \multicolumn{3}{c}{ Use } & \\
\cline { 2 - 5 } & $\begin{array}{c}\text { Famine food/ } \\
\text { chewing }\end{array}$ & Fodder & $\begin{array}{c}\text { Sanitation/ } \\
\text { medicinal }\end{array}$ & Fumigation \\
Acacia senegal & $+/-$ & + & - & - \\
Acacia seyal & $-/-$ & + & - & - \\
Acacia mellifera & $-/+$ & + & - & - \\
Boswellia papyrifera & - & + & + & + \\
Boswellia neglecta & $-/+$ & + & - & + \\
Boswellia microphylla & $-/+$ & + & - & + \\
Boswellia rivae & $-/+$ & + & - & + \\
Commiphora baluensis & $-/+$ & + & - & + \\
Commiphora kua & $+/+$ & + & + & + \\
Commiphora habessinica & $-/+$ & + & + & + \\
Commiphora africana & $-/-$ & + & + & + \\
Commiphora myrrha & $-/-$ & + & + & + \\
Commiphora terebinthina & $-/-$ & + & - & + \\
Commiphora confusa & $-/+$ & + & - & + \\
Commiphora boranensis & $-/+$ & + & - & + \\
\hline
\end{tabular}

Source: Lemenih et al. (2003), Worku (2006)

Timber from stands is used for fuel, construction and household utensils, which are either used in the household or sold for additional income.

\subsubsection{Ecological significance}

Gum- and resin-producing trees are characteristic plants of the drier low-lying ASALs. These trees are distributed across an altitudinal range of 200-2000 masl. The hot and dry regions in which these trees naturally occur are vulnerable to the effects of desertification and threats from global climate change. In this situation, the existence of vegetation, especially vegetation with economic importance, is of great significance. Such vegetation offers better options for adaptation to and mitigation of climate change. The vegetation resources could: (1) help to fight against desertification and soil erosion by water and wind; (2) contribute to the conservation and enhancement of biodiversity; (3) improve soil fertility; and (4) provide opportunities for C-sequestration. Indeed, Acacia, Boswellia and Commiphora species could be managed to provide multiple services, both economic and ecological. Such services would also enable Ethiopia to successfully comply with the various international conventions it has ratified, 
such as the CBC, CCD and FCCC. The following paragraphs look at the roles of this vegetation type in addressing issues related to these conventions.

\subsubsection{Potential for combating desertification}

Many techniques for desertification control involve improving degraded areas using vegetation and preventing/controlling soil erosion by wind. As desertification is driven by factors related to the rural economy, an eco-economic model for developing the rural economy must be formed and applied to control desertification (Shengyue and Lihua 2001). Acacia, Boswellia and Commiphora species, which are naturally adapted to and thrive in desertification-prone ASALs, offer a suitable means to integrate economics with desertification control (Lemenih and Teketay 2003a). These plants have proven useful as windbreaks and shelterbelts against desert encroachment. Their canopies intercept raindrops and their root systems are effective in reducing soil erosion, thereby stabilising soils (Jaiyeoba 1996). The fact that gum and resin collection is non-destructive means the vegetation can provide constant ground cover, thus preventing or reducing soil erosion and controlling desertification. Therefore, by managing dryland vegetation resources for sustainable economic benefits, their ecological services in desertification control can also be realised (Lemenih and Teketay 2004).

\subsubsection{Potential for biodiversity conservation}

Acacia, Boswellia and Commiphora species can be managed to contribute to biodiversity in 2 main ways. The first way is through gum and incense extraction. Extraction of gum and incense, when properly conducted, is non-destructive, and thus causes no damage to biodiversity; hence, the economic benefit and biodiversity value intersect.

The second way is by integrating the species with other economic sectors. Acacia, Commiphora and Boswellia species can be integrated with dryland farming systems in different forms of agroforestry, which is receiving considerable attention as an integrated approach to biodiversity conservation. In fact, Ethiopian farmers have long since developed various traditional agroforestry systems as coping mechanisms in the face of dwindling forest resources and products. Traditional agroforestry practices such as parkland, homestead and farm boundary tree management have been developed and practised for centuries. These practices have obviously created refuge for several indigenous tree species, many of which are endangered in natural stands. The agroforestry approach has also been acknowledged as an important strategy for controlling desertification and conserving biodiversity, particularly in dryland regions. This form of land use can allow biodiversity conservation in dryland zones even with a high rural population density (Le Houerou 1996). 
Many Acacia, Boswellia and Commiphora species possess the necessary qualities to be integrated in agroforestry systems. Acacia trees improve soil fertility through $\mathrm{N}$-fixation, provide shade for crops and workers and supply fuelwood and fodder. Several studies have demonstrated the potential of these parkland trees for enhancing crop production and soil fertility (Poschen 1986, Chadhokar 1989, Jiru 1989).

\subsubsection{Potential for carbon sequestration and climate change response}

Ethiopia’s current level of greenhouse gas emissions is negligible compared with those of developed countries. In Ethiopia, land use change, through deforestation and the conversion of forests into farmlands, is the principal source of $\mathrm{CO}_{2}$ emissions, accounting for nearly $81 \%$ of the $16297 \mathrm{Gg}$ annual emissions of $\mathrm{CO}_{2}$ in Ethiopia (Woldegiorgis 1995).

As a signatory to the FCCC, Ethiopia is obliged to join ongoing efforts for $\mathrm{C}$-sequestration by making use of various sink potentials. Drylands are probably the most difficult environments in which to achieve large amounts of C-sequestration, especially in the form of organic carbon. Inadequate rainfall limits the production and storage of high biomass (primary productivity), thereby resulting in the sparse distribution and low stature of the vegetation. In addition, poorly developed shallow soils, with low organic matter content, are common in dryland regions, and the high temperatures prevalent in the dryland environment imply that the turnover of $\mathrm{C}$ is rapid, meaning its significant storage in the soil will be difficult. These facts indicate that $\mathrm{C}$-sequestration attempts may not be easy or convenient in drylands.

The most viable approach to achieve significant C-sequestration in drylands is by means of productive vegetation management practices. Reducing dryland degradation and increasing biomass through improved management can offer large opportunities for $\mathrm{C}$-sequestration in both the soil and biome, and the reduction of other factors, such as dust and aerosols, can have a direct effect upon climate change. Such activities can also qualify for emerging carbon finance initiatives such as REDD (reducing emissions from deforestation and degradation). If successful, REDD could provide considerable financial incentives to fight poverty in dryland areas that will help strengthen their adaptation capacity. The fact that Acacia, Boswellia and Commiphora species can grow in harsh environments means there is potential to sequester carbon even in such extreme environments. The plants can also act as windbreaks and, thus, reduce loss of soil $\mathrm{C}$ by wind; furthermore, by intercepting raindrops in wide-spreading canopies, they can reduce the speed of surface run-off and thus reduce soil erosion, thereby effectively stabilising soils and protecting soil carbon. The predominance of $\mathrm{N}$-fixing Acacia species in the dryland vegetation would mean higher soil fertility and higher potential, at least in the context of drylands, for 
higher soil C sequestration. $\mathrm{N}$-fixing-vegetation has been shown to provide greater potential for soil C-sequestration than non-N-fixing vegetation (Lemenih and Itana 2004).

\subsection{Degradation of gum and resin resources and major causes}

Ethiopia's dryland vegetation resources are facing a severe threat of degradation from several forces - mainly human-induced. Drivers of dryland degradation include population growth and farmland expansion, lack of regeneration, human-induced fires, improper use of woodlands, improper tapping, overgrazing and bush encroachment (Ogbaghzi 2001, Eshete et al. 2005, Worku 2006).

\subsubsection{Lack of adequate regeneration}

Several studies have observed that young trees (seedlings and saplings) for most of the gum- and resin-producing species are consistently absent from their natural environments (Eshete 2002, Worku 2006, Lemenih et al. 2007, Dejene 2008). For instance, for B. papyrifera, some studies report that $65 \%$ of the total population falls into the diameter categories of $13-15 \mathrm{~cm}$ and $16-24 \mathrm{~cm}$. Under normal regeneration conditions, the population structure should show an inverted-J shape, with a higher density of lower diameter classes than of higher diameter classes. However, the low density of individuals in the lower

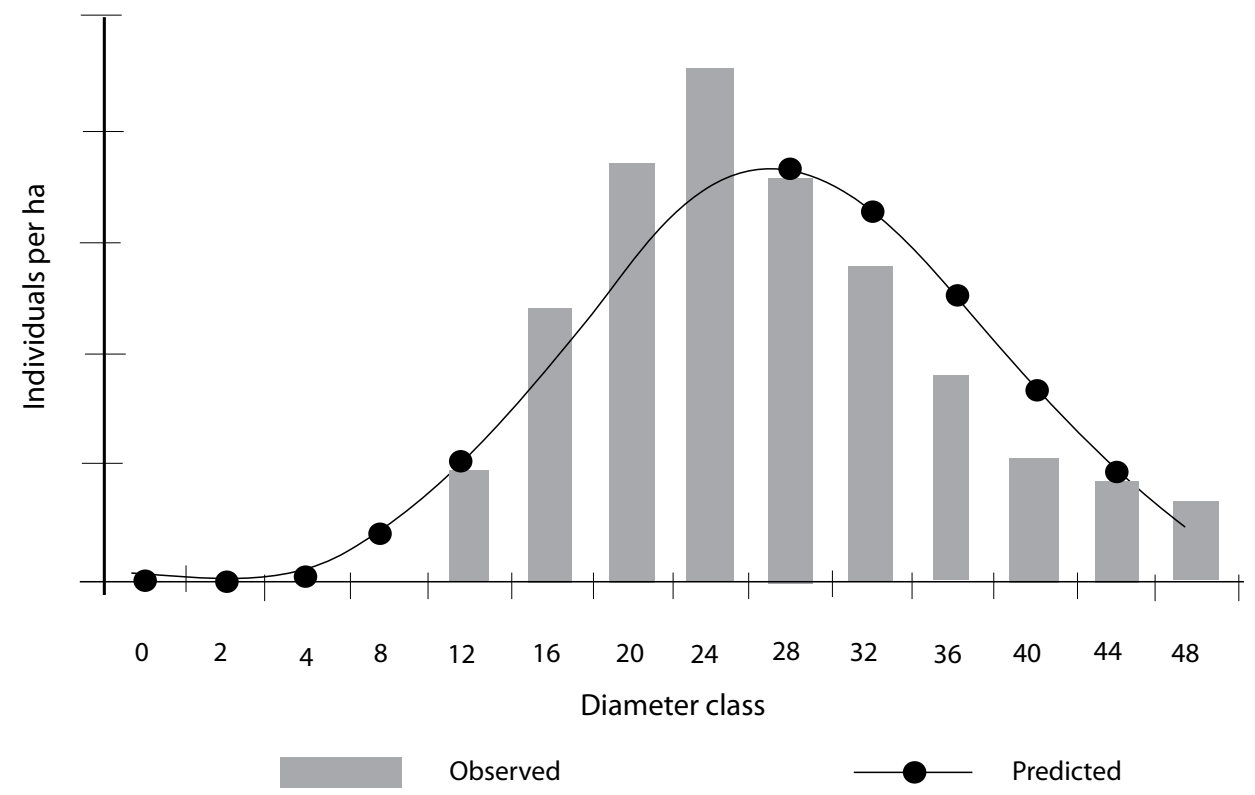

Figure 2.9 Population structure of B. papyrifera in Metema district, northwestern Ethiopia.

Source: Dejene (2008) The predicted curve was derived using the Weibull distribution function. 
diameter classes (Figure 2.9) suggests that regeneration and new recruitment are not occurring and that the population is unstable or threatened by unsustainable conditions.

Several factors are possible causes of the inadequate regeneration, as detailed below.

1. Reduced quality and quantity of seeds. Studies reveal that Boswellia trees produce fewer and lower-quality seeds when intensively tapped (Ogbazghi 2001, Eshete et al. unpubl.). This leads to low germination and regeneration rates. For instance, Ogbazhgi (2001) shows that germination rates for seeds from intensively tapped trees were $14 \%$ compared with rates of more than $80 \%$ for seeds from untapped stands. Similarly, Eshete et al. (unpubl.) show that untapped trees yield significantly higher numbers of viable (germinable) seeds than continuously tapped trees. The same study shows that the effect of tapping is more pronounced in older trees than in younger ones. Tapped stands also produce seeds with a higher incidence of insect attack and a higher proportion of unfilled seeds than untapped stands. Therefore, tapping, by interfering with tree physiology, results in the production of a high proportion of unfilled seeds and seeds that are vulnerable to opportunistic predators. These seeds fail to produce seedlings, leading to insufficient natural regeneration.

2. Seedling damage due to overgrazing. Overgrazing is another cause of low regeneration. Seedling establishment has been found to be better in enclosed or fenced experimental plots than in openly grazed sites (Ogbazhgi 2001), although new unpublished studies by Eshete (personal communication) do not support this conclusion. Rather, Eshete's research indicates that seedling mortality for B. papyrifera remains high in both enclosed and openly grazed sites. The seeds and seedlings of most gum and resin trees are vulnerable to grazing because (a) their seeds have epigeal growth; (b) the seedlings are succulent and palatable and are therefore preferred by livestock and wildlife for browse; and (c) the seedlings grow too slowly to escape grazers. In Eritrea, for instance, after 3 years, seedlings attained a maximum height of only 15 $\mathrm{cm}$ and a basal diameter of $1.5 \mathrm{~cm}$ (Ogbazghi 2001). This extended juvenile period increases the seedlings' risk of being eaten, trampled or damaged.

3. Damage by fire. Another factor in this respect is fire, which can kill most seedlings. Fire intensity and frequency have increased in most dryland areas because of population growth, which means fires wreak more damage than under natural occasions. The increased fire intensity is damaging the young seedlings, leading to their poor survival. 


\subsubsection{Population pressure}

Population growth is a major driver of woodland degradation in Ethiopia.

Population growth in woodland areas has been spurred government-sponsored resettlement programmes and self-initiated migration in search of croplands.

As a strategy to enhance food security, successive governments during the past 30 to 40 years have implemented resettlement programmes for vulnerable people, moving them from degraded highlands to dry forest areas. For example, in 2002-2005, about 340000 households were officially resettled from 3 regional states (Tigray, Amhara and Oromia). Resettlement is an ongoing programme, with 161108 households targeted for resettlement in 2005-2010 (PASDEP 2005). Most of the resettlements are taking place in lowland dry forests. For instance, in Tigray the major resettlement is in Humera, and in Amhara Regional State, Metema and Quara are major recipients of resettlers. In Metema district, the native Gumuz community makes up only $2 \%$ of the total population of 78741 , meaning 77141 individuals are migrants of one form or another. Furthermore, during 1995-1998 EC, 2 about 18586 household heads were officially resettled in Metema through the Amhara Regional State resettlement programme.
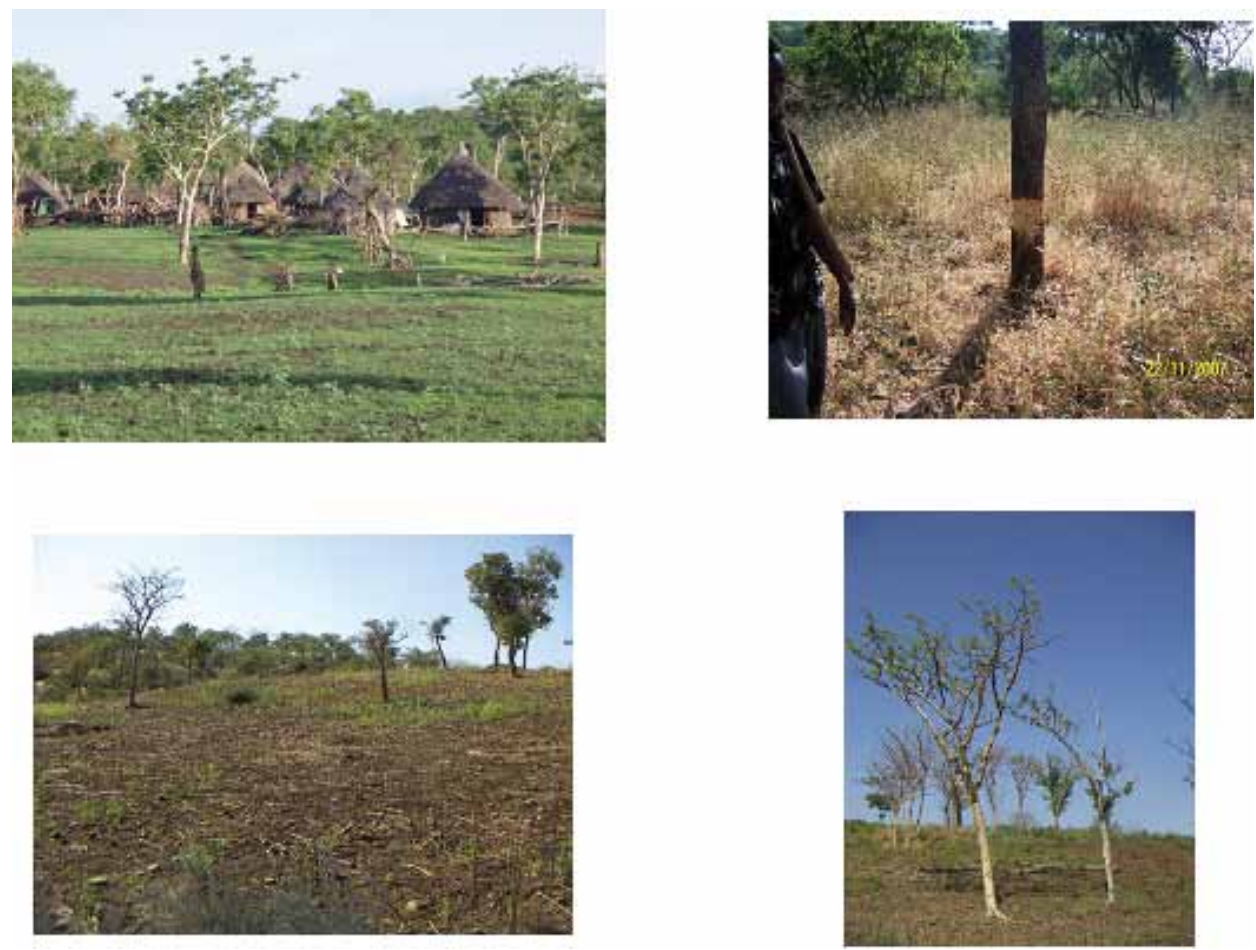

Figure 2.10 Settlement parcels and agricultural fields in the midst of Boswellia forest in Metema district. Photo $\odot$ M. Lemenih

2 EC stands for Ethiopian Calendar. Ethiopian dates are 7 and 8 years behind European dates for the months from September to December and January to August, respectively. 
The population increase affects the dry forests in several ways. Clearance of woodlands for cropland expansion is probably the major effect. For instance, in addition to the officially allocated 2 ha of land for each household resettled, recent research shows that land holdings per household in Metema district exceed 7 ha (Lemenih et al. 2007, Dejene 2008), indicating the large impact of the population influx. If considering only the official land allocation of 2 ha per household, at least 37172 ha of woodland in the district was converted to agricultural land in a period of just 4 years. In general, estimates show that nearly 303180 ha of woodland in Metema district was converted into arable land and settlements in a period of 30-35 years (Figure 2.10). Similarly, in Tigray Regional State, more than 177000 ha of Boswellia forest has reportedly been destroyed in the past 20 years (Gebrehiwot 2003). Multi-temporal satellite image analyses in Pawe, a district that has received large numbers of resettlers, show that bare areas and grasslands increased by 659.6 ha $(1.78 \%)$ and 8956.3 ha $(23.8 \%)$ respectively, in just 15 years, and that 18365.8 ha of bamboo forests and woodland thicket was lost following resettlement during the same period. Agricultural land/settlements increased by 6876.5 ha (18.3\%) during the same period (Figure 2.11).

Population growth, particularly through resettlement, also affects woodlands through wood harvest for such purposes as house construction, fencing, firewood and charcoal for domestic use and sale. For instance, according to information from Metema district, hut construction consumes on average 150 logs plus 180 bamboo stems.

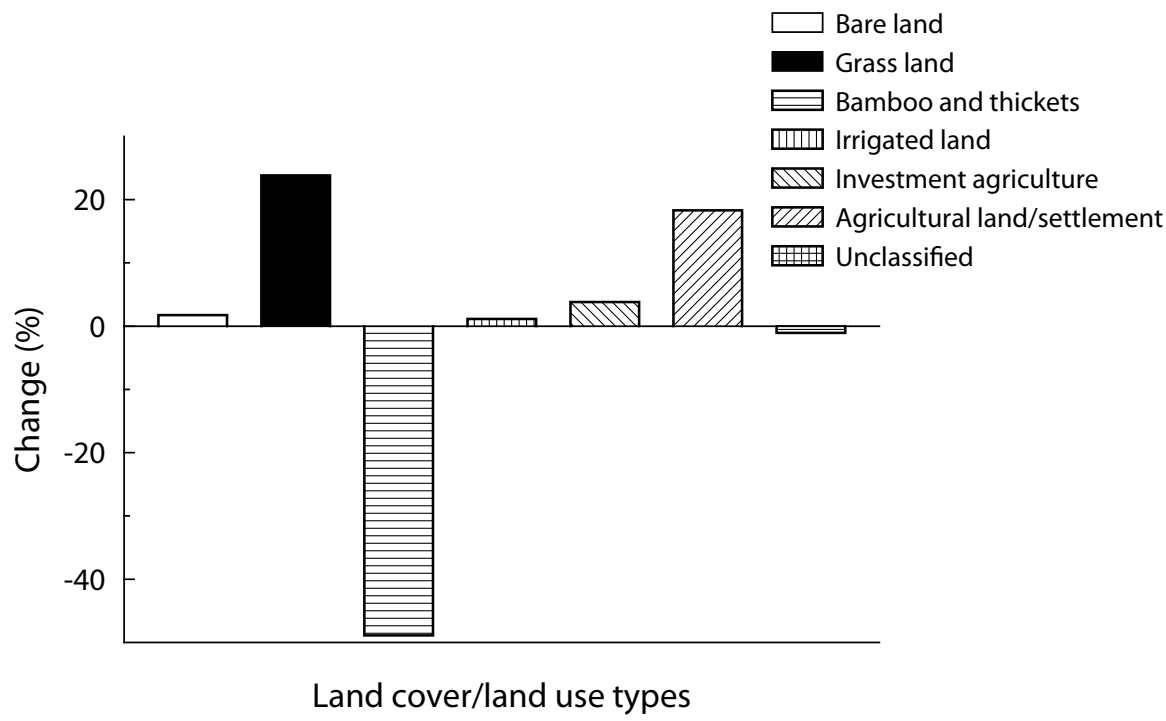

Figure 2.11 Change in land cover and land use over a 15-year period

Source: Kebede (2006) 


\subsubsection{Overgrazing}

Ethiopia's livestock population is the largest in sub-Saharan Africa. Livestock rearing is an integral component of Ethiopian farming culture, in both highlands and lowlands, and has major economic and social functions in the rural sector. Ethiopia is home to about 35 million tropical livestock units (TLU), equivalent to 70-80 million heads. The country has 30 million head of cattle, more than 42 million head of sheep and goats and 7 million equines (FAO 2004). Nearly 30\% of the livestock population is concentrated in ASALs. Moreover, highlanders migrate with their cattle to lowlands during the rainy season, a period when the highlands are fully under crop cultivation. Excluding this seasonal migration, the density of livestock is 160 TLU per square kilometre in Ethiopia, which is significantly higher than the recommended TLU level for both humid and semiarid areas, resulting in widespread overgrazing and land degradation (FAO/ World Bank 1996).

The Ethiopian livestock sector degrades forest because, under its open pasture production system, animals graze and browse freely (Figure 2.12). Farmlands, natural woodlands, forestlands and grasslands all serve as open pasture. Studies indicate that forests and woodlands provide $15 \%$ and $60 \%$ of feed for livestock during rainy season and dry seasons, respectively.

The free grazing system implies that animals can browse on seedlings and samplings, as well as debarking mature trees. Consequently, the ecological disturbance and damage caused by overgrazing, particularly the negative impacts on natural regeneration of woody species - including resin-producing plants - is immense (Eshete 2002). Changing life styles, from nomadism to semi-
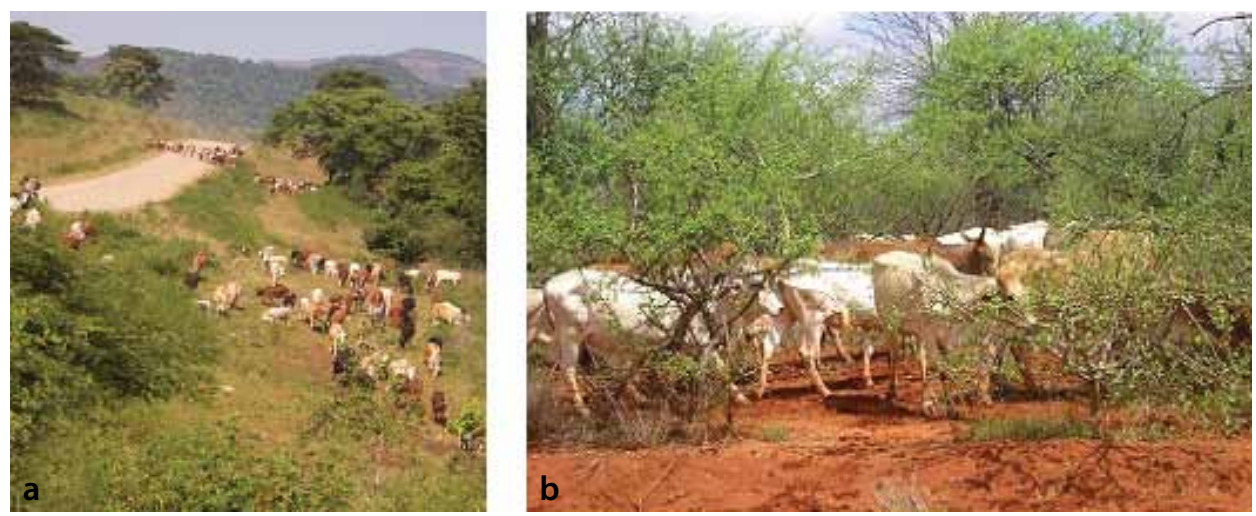

Figure 2.12 High livestock populations in the dryland forests of (a) Metema and (b) Borana lowlands, resulting in overgrazing. Photo $\odot$ M. Lemenih (a) and A. Worku A (b). 
permanent or permanent settlements, as encouraged by population pressures, is also breaking down the traditional and relatively sustainable system of woodland management in several dryland areas such as Borana (Dalle 2004). Consequently, large livestock populations are confined to small areas, leading to severe vegetation and other ecological damage.

\subsubsection{Fire}

Fire is a component of traditional savannah and woodland vegetation management, particularly by cattle herders and pastoralists (Figure 2.13). Although the vegetation in dryland areas evolved under cyclic fire, species such as $B$. papyrifera need some fire-free years to allow enough regeneration and the development of seedlings into saplings and poles to maintain the populations (Menaut et al. 1995). However, in most cases, woodland vegetation is exposed to annual burning, which severely affects not only delicate seedlings but also mature trees (Eshete 2002).Furthermore, tapped trees (e.g. B. papyrifera) are more susceptible to fire damage than untapped trees, because the resin they exude is highly inflammable, intensifying the fire and causing tree death.

\subsubsection{Improper tapping practices and inadequate resting periods}

Boswellia trees, specifically B. papyrifera, are tapped to produce frankincense. Tapping involves making incisions in (wounding) the tree body. Incisions are made by shaving off the bark of the trees using sharp instruments. The depth, intensity and frequency of the incisions vary according to the tapper, as no

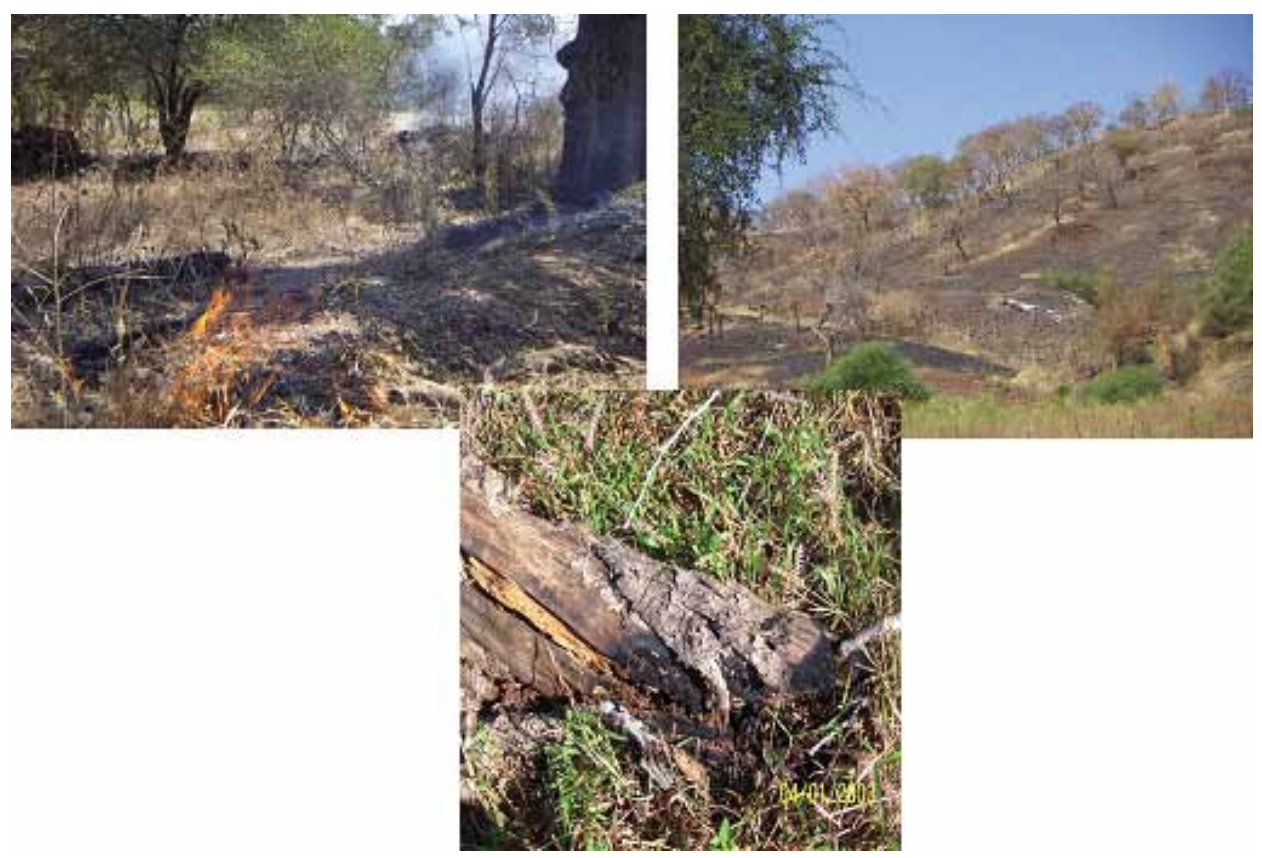

Figure 2.13 Dry forests of Metema district damaged by fire. Photo $\odot$ Lemenih $M$. 
standards, training or monitoring apply to the practice. Careless tapping and repeated intense wounding in an attempt to increase yield are harmful to the trees. Furthermore, deep incisions that affect the inner bole (the sapwood) of the trees can cause the trees to dry up and die (Tadesse et al. 2002). Deeper incisions lead to prolonged healing periods; this is exacerbated because wounding is done during the dry season when poor growth conditions inhibit quick healing. There are also indications that incisions predispose trees to insect and pathogenic infections (Farah 1994, Gebremedhin 1997). Incisions create a route by which woodborers and other parasites can access and infect the trees. Such infections coupled with the trees' weakened resistance due to intense wounding in dry seasons frequently cause the trees to die (Farah 1994, Gebremedhin 1997).

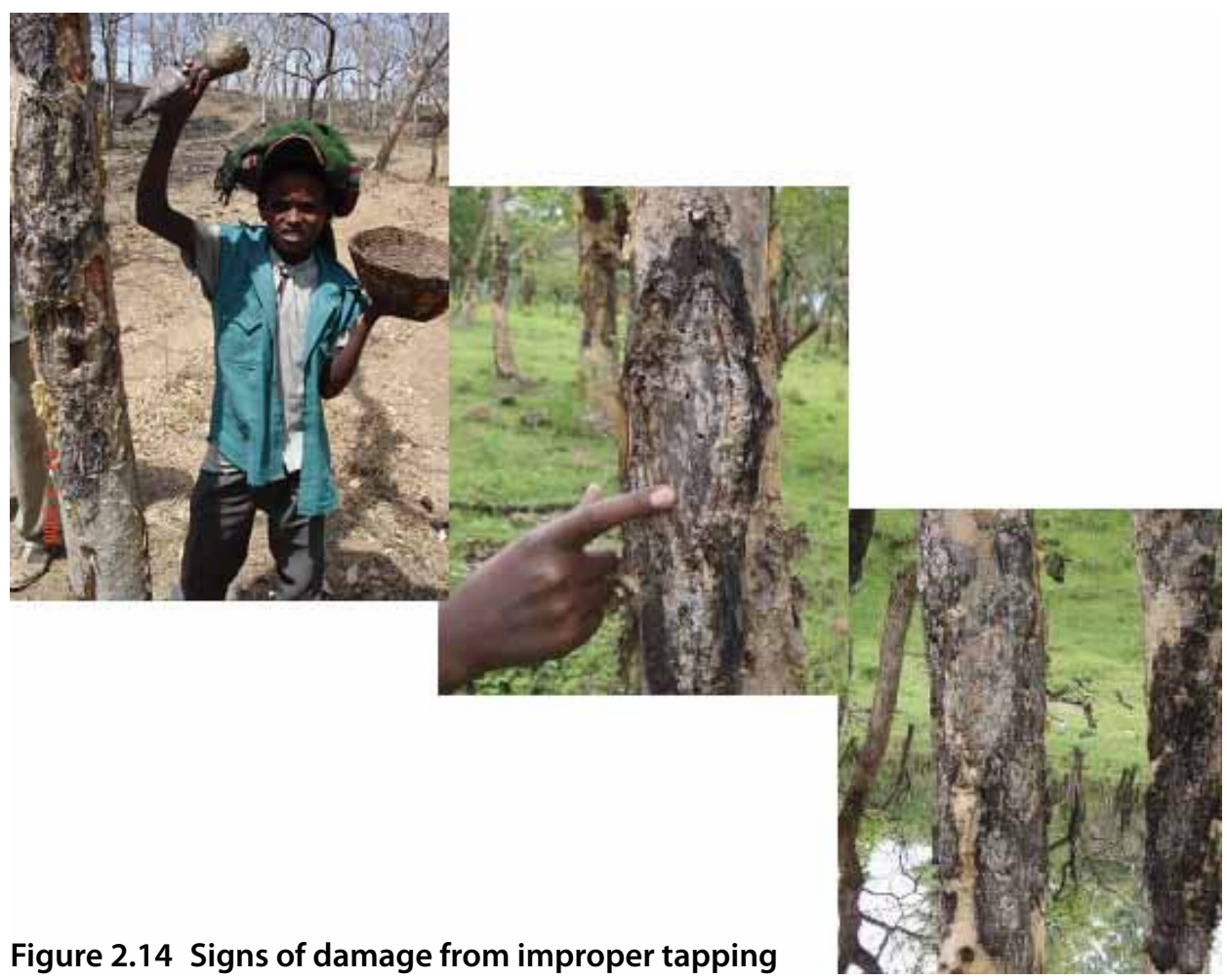

Under best practice, a tree is tapped for no more than 3 consecutive years, and should be rested so it can recover and regain vigour. However, in most cases, Boswellia trees are repeatedly tapped at intervals of 15 days throughout the dry season for up to 7 or more years. This causes premature death and production of poor-quality seeds that are unable to regenerate (Figure 2.14). 


\subsubsection{Bush encroachments}

Several native and alien species such as A. drepanolobium, A. mellifera, and Prosopis juliflora are emerging as threats to native plant species biodiversity in Ethiopia. This is particularly affecting gum- and resin-producing species in the country's southern, central and eastern lowlands.

\subsubsection{Institutional factors}

Weak governance and regulatory frameworks in terms of policy, legislation and institutional arrangements are adding to the rapid degradation of dry forest species in Ethiopia. There are four main issues.

Short-term land leasing for production. This is blamed for overextraction and thus damage to the stands.

Weak controls on production processes and intensity. The absence of institutions responsible for following up on production processes means trees are vulnerable to improper tapping practices such as the use of unskilled labour or inappropriate tapping intensity for tree size. In the absence of a monitoring body, concessionaires and even farmers are striving to maximise production for shortterm benefit.

Lack of community participation in production and forest management. In most production areas, local communities have no incentive to share either the management responsibility or the benefits accruing from the forest resources in their vicinity. Rather, people from outside areas often engage in production, which strips locals of any sense of ownership and thus responsibility for forest stewardship. Instead, farmers often compete to convert land into farmlands, as this creates greater entitlement and ownership.

Lack of management plans and supervision of forest use. Ethiopian forests, including dry forests, are legally state property. The low capacity of government institutions means proper forest management does not take place in reality. Consequently, forests are mined rather than managed, which accelerates their already rapid degradation.

\subsection{Options for restoration}

Insufficient regeneration of Boswellia forests and the decline of natural stands of dryland forests are evident. No plantations of any gum- and resin-producing species have been established in Ethiopia, with the exception of small plantation trial stands of $A$. senegal. Furthermore, there are few instances of cutting trails being established, as in the Blue Nile gorge for B. papyrifera. Most gum- and resin-producing species can be propagated via many means such as from natural seed germination (wildings), nursery seedling production and transplantation, rooted cuttings and root sprouting/suckers (Figure 2.15). 


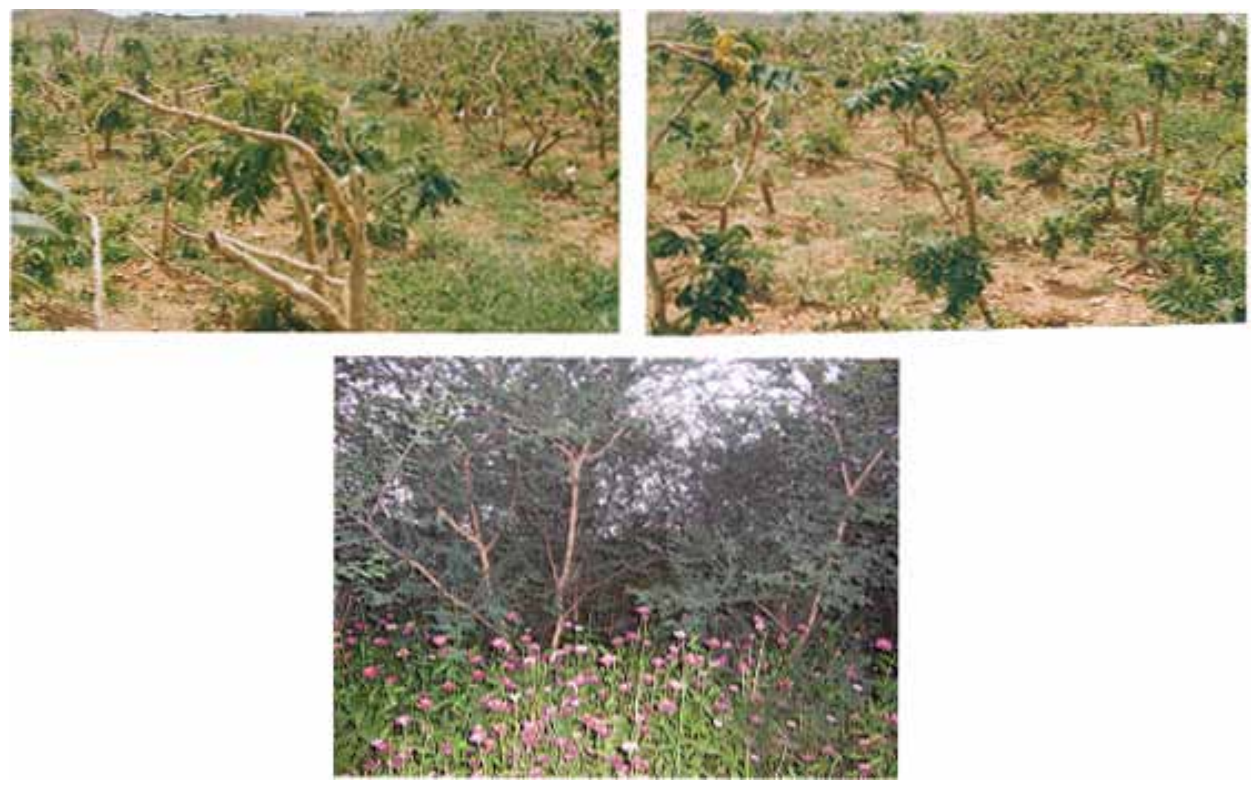

Figure 2.15 Vegetative propagation of B. papyrifera (top) and planted stand of $A$. senegal (bottom)

Following are some possibilities for conserving and improving the dryland woodlands.

- Plantation establishment and woodland management. Both the government and the private sector should be involved in this. Management involves enrichment plantings, protection, improved production systems, etc.

- Rational planning in settlement programmes; training and retraining of settlers to responsibly use and live with the resources.

- Leasing, policy support and incentive provision to encourage private sector involvement in planting and managing the resources on a long-term basis.

- Effective coordination and integration of all efforts to ensure sustainability.

\section{References}

Asfaw, S. 2006 Effects of fire and livestock grazing on woody species composition, structure, soil seed banks and soil carbon in woodlands of North Western Ethiopia. Master's thesis, University of Natural Resources and Applied Life Sciences, Vienna, Austria.

Chadhokar, P.A. 1989 Silvopastoral system in soil conservation in Ethiopia. In: Proceedings of IAR/ICRAF National Agroforestry Workshop, 23-28. Awassa, Ethiopia, 14-18 November 1988. 
Coppen, J.J.W. 1995 Flavours and fragrances of plant origin. Non-wood forest products series, no. 1. Food and Agriculture Organization of the United Nations, Rome. 101p.

Dalle, G.T. 2004 Vegetation ecology, rangeland condition and forage resources evaluation in the Borana lowlands, southern Oromia, Ethiopia. Dissertation. Cuvillier Verlag, Göttingen, Germany.

Dejene, T. 2008 Economic valuation of alternative land uses in Boswellia papyrifera dominated woodland area of Metema, north Gondar Ethiopia. Master's thesis, Wondo Genet College of Forestry, Awassa, Ethiopia.

Eshete, A. 2002 Regeneration status, soil seed banks and socio-economic importance of B. papyrifera in two woredas of North Gonder Zone, Northern Ethiopia. Master's thesis, Swedish University of Agricultural Sciences, Skinnskatteberg, Sweden.

Eshete, A., Teketay, D. and Hulten, H. 2005 The socio-economic importance and status of populations of Boswellia papyrifera (Del.) Hochst in Northern Ethiopia: the case of North Gonder Zone. Forests, Trees and Livelihoods 15: 55-74.

Farah, A.Y. 1994 The milk of the Boswellia forests: frankincense production among the pastoral Somali. Department of Social and Economic Geography, Uppsala University, Uppsala, Sweden.

Fitwi, G. 2000 The status of gum arabic and resins in Ethiopia. In: Report of the meeting of the Network for Natural Gums and Resins in Africa (NGARA): proceedings. Nairobi, Kenya, 29-31 May.

Food and Agriculture Organization of the United Nations (FAO) 1995 Gums, resins and latexes of plant origin. Non-wood forest products 6. FAO, Rome.

Food and Agriculture Organization of the United Nations (FAO) 1988 Nonwood forest product in Ethiopia assignment to compile data. FAO, Addis Ababa, Ethiopia.

Food and Agriculture Organization of the United Nations (FAO) 2004 Livestock sector brief: Ethiopia. FAO, Livestock Information Sector Analysis and Policy Branch, Addis Ababa, Ethiopia.

Gebrehiwot, K. 2003 Ecology and management of Boswellia papyrifera (Del.) Hochst dry forests in Tigray, Northern Ethiopia. PhD thesis, Georg-August University of Göttingen, Gottingen, Germany.

Gebrehiwot K., Muys B, Haile M, Mitloehner R. 2002. Introducing Boswellia papyrifera (Del.) Hochst and its non-timber forest product, frankincense. International Forestry Review 5: 348-353.

Gebremedhin, T. 1997 Boswellia papyrifera from the Western Tigray: opportunities, constraints, and seed germination responses. Master's thesis, Swedish University of Agricultural Sciences, Skinnskatteberg, Sweden.

Jaiyeoba, I.A. 1996 Amelioration of soil fertility by woody perennials in cropping fields: evaluation of three tree species in the semi-arid zone of Nigeria. Journal of Arid Environments 33: 473-482. 
Jiru, D. 1989 Evaluation of crop yield under Acacia albida shade and alley cropping in semiarid farms. In: Proceedings of IAR/ICRAF National Agroforestry Workshop, 33-38. Awassa, Ethiopia, 14-18 November 1988.

Kebede, B. 2006 Land cover/land use changes and assessment of agroforestry practices at Pawe resettlement district, northwestern Ethiopia. Master's thesis, Wondo Genet College of Forestry and Natural Resources, Awassa, Ethiopia.

Kuchar, P. 1988 The plants of Somalia: an overview and checklist. Revised draft. Louis Berger International-United States Agency for International Development, Centre régional de documentation pédagogique CRDP, Mogadishu, Somalia. 329p.

Kuchar, P. 1995 Identification and characterization of Boresraceae in the southeastern Ethiopia. Southeastern rangelands project technical paper. Addis Ababa, Ethiopia. 57p.

Le Houerou, H.N. 1996 Climate change, drought and desertification: review. Journal of Arid Environments 34: 133-185.

Lemenih, M. 2005 Production and marketing of gums and gum resins in Ethiopia. In: Ben, C. and Enrico, C. (eds) Production and marketing of gum resins: frankincense, myrrh and opoponax, 55-70. Food and Agriculture Organization of the United Nations/Network for Natural Gums and Resins in Africa, Nairobi, Kenya.

Lemenih, M. and Itana, F. 2004 Soil carbon stocks under various vegetation types and its dynamics following deforestation and conversion to arable lands along an elevation gradient in southern Ethiopia. Geoderma 123: 177-188.

Lemenih, M. and Kassa, H. 2008 Management guidelines for Boswellia papyrifera and its frankincense in Ethiopia. Center for International Forestry ResearchEthiopia, Addis Ababa, Ethiopia.

Lemenih, M. and Teketay, D. 2003a Frankincense and myrrh resources of Ethiopia. I. Distribution, production, opportunities for dry land economic development and research needs. Ethiopian Journal of Science, SINET 26: 63-72.

Lemenih, M. and Teketay, D. 2003b Frankincense and myrrh resources of Ethiopia. II. Medicinal and industrial uses. Ethiopia Journal of Science, SINET 26: 161-172.

Lemenih, M. and Teketay, D. 2004 Natural gum and resin resources: opportunity to integrate production with conservation of biodiversity, control of desertification and adapt to climate change in the dry lands of Ethiopia. In: Proceedings of a Workshop on Conservation of Genetic Resources of Non Timber Forest Products (NTFPs) in Ethiopia, 37-49. Addis Ababa, Ethiopia, 5-6 April.

Lemenih, M., Abebe, T. and Olsson, M. 2003 Gum and resin resources from some Acacia, Boswellia and Commiphora species and their economic contributions in Liban, Southeast Ethiopia. Journal of Arid Environments 55: 465-482. 
Lemenih, M. Feleke, S. and Tadesse, W. 2007 Factors constraining the production and marketing of frankincense by local people in Metema district, NorthWestern Ethiopia. Journal of Arid Environments 71: 393-403.

Menaut, J.C., Lepage, M. and Abbadie, L. 1995 Savannas, woodlands and dry forests in Africa. In: Bullock S.H., Mooney H.A. and Medina E. (eds) Seasonally dry tropical forests, 64-92. Cambridge University Press, Cambridge, UK.

Negussie, A., Aerts, R., Gebrehiwot, K. and Muys, B. 2008 Seedling mortality causes recruitment limitation of Boswellia papyrifera in northern Ethiopia. Journal of Arid Environments 72: 378-383.

Ogbazghi, W. 2001 The distribution and regeneration of Boswellia papyrifera (Del.) Hochst in Eritrea. PhD thesis, Wageningen University, Wageningen, The Netherlands.

Ogbazghi, W., Bongers, F., Rijkers, T. and Wessel, M. 2006 Population structure and morphology of the frankincense tree Boswellia papyrifera along an altitude gradient in Eritrea. Journal of the Drylands 1: 85-94.

Plan for Accelerated and Sustained Development to End Poverty (PASDEP) 2005 Ethiopia: building on progress: a plan for accelerated and sustained development to end poverty 2005/06-2009/10. Ministry of Finance and Economic Development, Addis Ababa, Ethiopia.

Poschen, P. 1986 An evaluation of the Acacia albida based agroforestry practices in the Hararge Highlands of eastern Ethiopia. Agroforestry System 4: 129-143.

Rijkers, T., Ogbazghi, W., Wessel, M. and Bongers, F. 2006 The effect of tapping for frankincense on sexual reproduction in Boswellia papyrifera. Journal of Applied Ecology 43: 1188-1195.

Shengyue, F. and Lihua, Z. 2001 Desertification control in China: possible solutions. (synopsis) Ambio 30(6): 384-385.

Tadesse, W., Teketay, D., Lemenih, M. and Fitwi, G. 2002 Review and synthesis on the state of knowledge of Boswellia species and commercialization of frankincense in the dry lands of eastern Africa. In: Chikamai, B.N. (ed.) Country report for Ethiopia, 11-35. Kenya Forestry Research Institute, Nairobi, Kenya.

Teketay, D. 1997 Seedling populations and regeneration of woody species in Afromontane forest of Ethiopia. Forest Ecology and Management 98: 149-165.

Tesfaye, G. 2008 Ecology of regeneration and phenology of seven indigenous tree species in a dry tropical afromontane forest, southern Ethiopia. PhD thesis, Addis Ababa University, Addis Ababa, Ethiopia.

Tesfaye, G., Teketay, D. and Fetene, M. 2002 Regeneration of 14 tree species in Harenna forest, southeast Ethiopia. Flora 197: 461-474.

Thulin, M. and Claeson, P. 1991 The botanical origin of scented myrrh (Bissabol or Habak Hadi). Economic Botany 45(4): 487-494. 
Tucker, A.O. 1986 Frankincense and myrrh. Economic Botany 40(4), 425-433.

Vollesen, K. 1989 Burseraceae. In: Hedberg, I. and Edwards, S. (eds). Flora of Ethiopia, Vol. 3, 442-478. National Herbarium, Addis Ababa University, Ethiopia and Uppsala University, Uppsala, Sweden.

Woldegiorgis, A. 1995 Ethiopia: greenhouse gas emissions and sources. In: Ramos-Mañé, C. and Benioff, R. (eds) Interim report on climate change country studies. http://www.gcrio.org/CSP/IR/IRethiopia.html [17 January 2011].

Worku, A. 2006 Population status and socio-economic importance of gum and resin bearing species in Borana lowlands, southern Ethiopia. Master's thesis, Addis Ababa University, Department of Biology, Addis Ababa, Ethiopia.

Yebeyen, D. 2006 Population status of Acacia senegal (linne) willdenow and its gum quality in the central rift valley of Ethiopia. Master's thesis, Wondo Genet College of Forestry, Awassa, Ethiopia. 



\section{Chapter 3}

\section{Production, handling and quality control}

Girmay Fitwi ${ }^{1}$ and Mulugeta Lemenih ${ }^{2}$

\subsection{Introduction}

This chapter presents information on the production processes, harvesting and handling, quality control and associated constraints in Ethiopia. It also proposes measures to improve product quality and to enhance gains from the subsector at both local and national levels.

\subsection{History of gum and resin production in Ethiopia}

According to oral legend, myrrh and incense production and trade in Ethiopia date back to the Aksumite Empire, which flourished around 500 BC (Gebremedhin 1998). The introduction of Christianity into the country around the $3^{\text {rd }}$ century AD is believed to have increased production and trade. Despite this, hardly any historical documentation or other solid evidence exists to unequivocally support claims of the ancient commercial production of myrrh and incense in Ethiopia. Available records for commercial production only date back to the 1940s (Taib 1982), when Italians introduced incense production into Ethiopia via Eritrea. Somalia also introduced production into Eritrea. Over time, commercial production extended further southwards through Ethiopia to other parts of the country, including Tigray, Metema (Amhara), Benishangul-Gumuz and Borana (Oromia) (Figure 3.1).

The organised production and trade of gums and resins by local companies began in the 1960s following the founding of a private company called Tigray Agricultural and Industrial Development Share Company (TAIDL), which was co-owned by the then government of Ethiopia and some private individuals. The company operated until 1974 when it was nationalised by the socialist

1 Natural Gum Production and Marketing Enterprise, Addis Ababa, Ethiopia

2 Hawassa University, Wondo Genet College of Forestry and Natural Resources, Ethiopia 


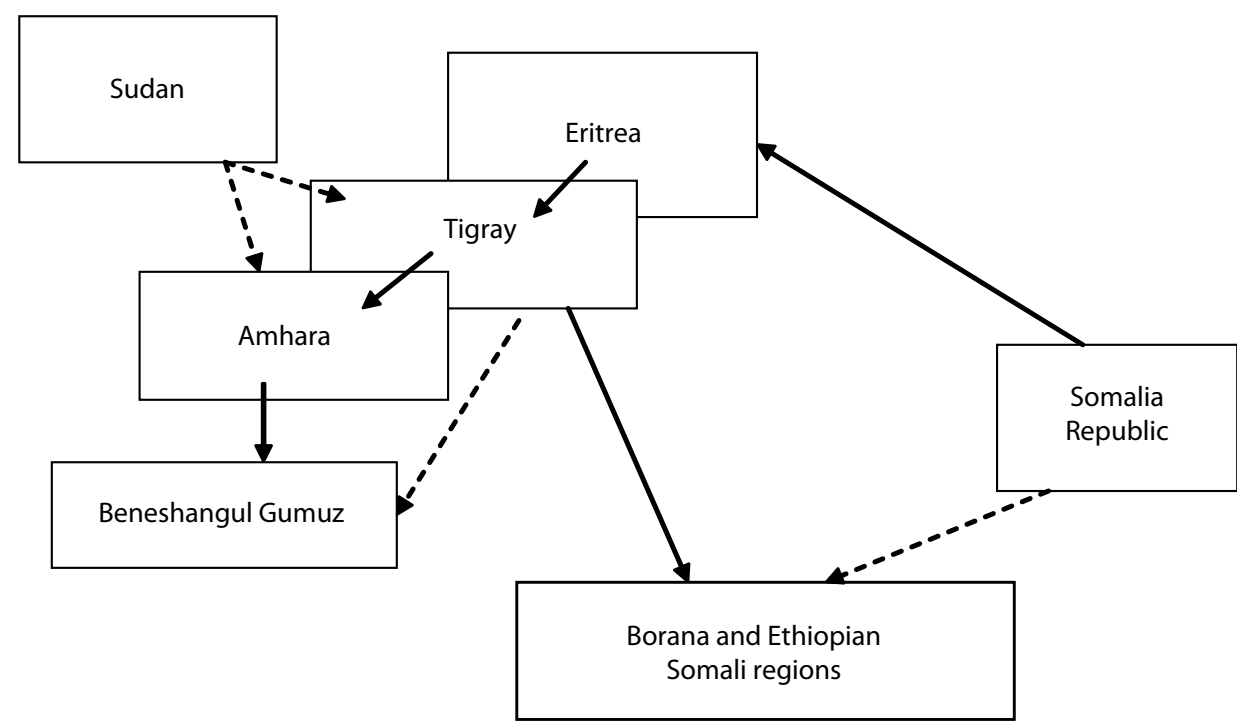

$\rightarrow$ Main historical route of production introduction to and in Ethiopia

$\rightarrow$ Possible alternative route of introduction or technology shopping

Figure 3.1 Historical development of commercial gum and resin production in Ethiopia

government, which soon established a state-based company called Natural Gum Processing and Marketing Enterprise (NGPME).

NGPME further expanded gum and resin production throughout the rest of the country. NGPME was also active in technology shopping, such as seeking tapping equipment for improved exploitation, from neighbouring countries, principally Sudan and Somalia (Figure 3.1). For 17 years (1974-1991), NGPME operated alone as the country's sole enterprise responsible for the production and marketing of gums and resins. Since 1991, following the fall of the socialist regime and the beginning of a free market economic policy, several private entrepreneurs have renewed their interest in gum and resin production and marketing. Today, 34 private companies are engaged in the production and/or trade of gums and incenses in various sites throughout the country.

\subsection{Production processes and gum handling}

The production of various gums and resins varies according to the type and place of production. Common to all, however, is the fact that production and harvesting are seasonal and performed solely during dry seasons. Production during rainy seasons is not recommended because of the rapid deterioration in 
quality in connection to the high moisture content. Ethiopia's current gum and resin production system can broadly be subdivided into 2 activities: production by tapping and collection of naturally oozing gums and resins.

\subsubsection{Tapping}

Tapping is the artificial wounding of the stems and branches of trees for the production of gums and resins. It involves shallow blazing (wounding) of the stems and branches by shaving off the bark using a sharp instrument, locally known as a mingaf or sonke (Figure 3.2).

When the stems and branches are blazed, incense begins to ooze through the openings created by the wounds. These incense tears start to solidify and granulate upon exposure to wind and sun radiation (Figure 3.3). Leaving
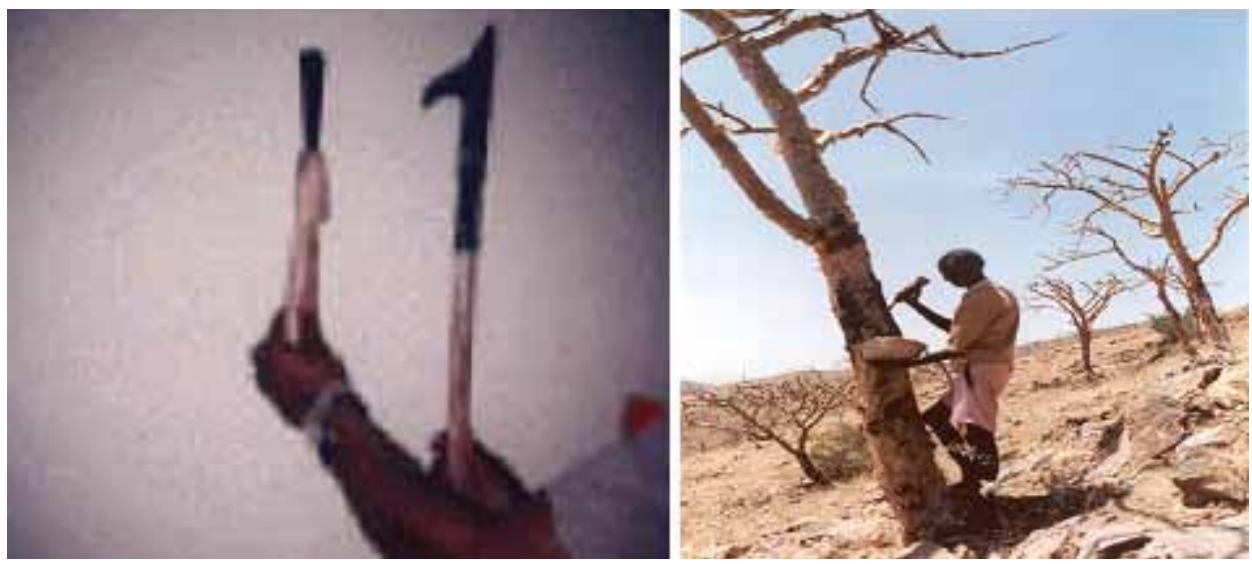

Figure 3.2 (a) Two of the most commonly used tapping tools (mingaf and sonke) and (b) tapping an incense tree

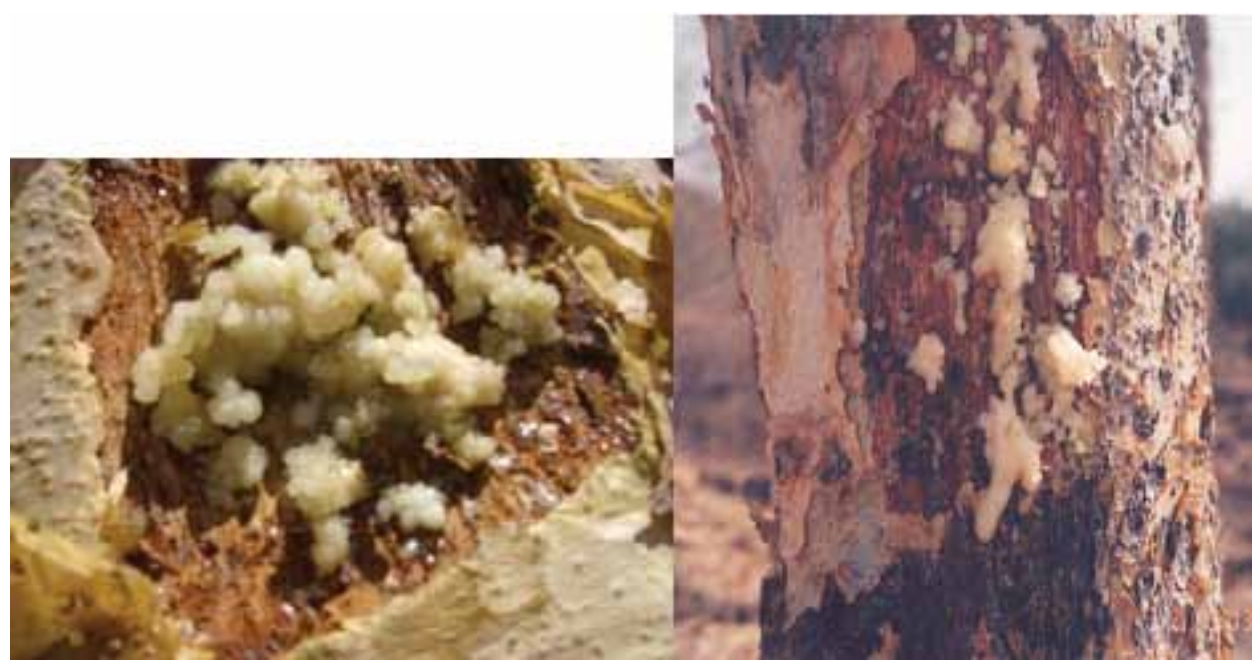

Figure 3.3 Solidifying tear of frankincense after artificial wounding of B. papyrifera 
the tears on the trees for a sufficient length of time is important to allow the tears to mature and to avoid them clumping into ungranulated masses. In Ethiopia, tapping is commonly practised for Tigray type incense production from B. papyrifera.

The tapping and collection of gum olibanum from B. papyrifera are carried out according to a specific pattern starting from mid-October until the onset of the rainy season, usually early June. Due to the mono-modal rainfall pattern in the north, production and collection take place for an extended 8-9 months each

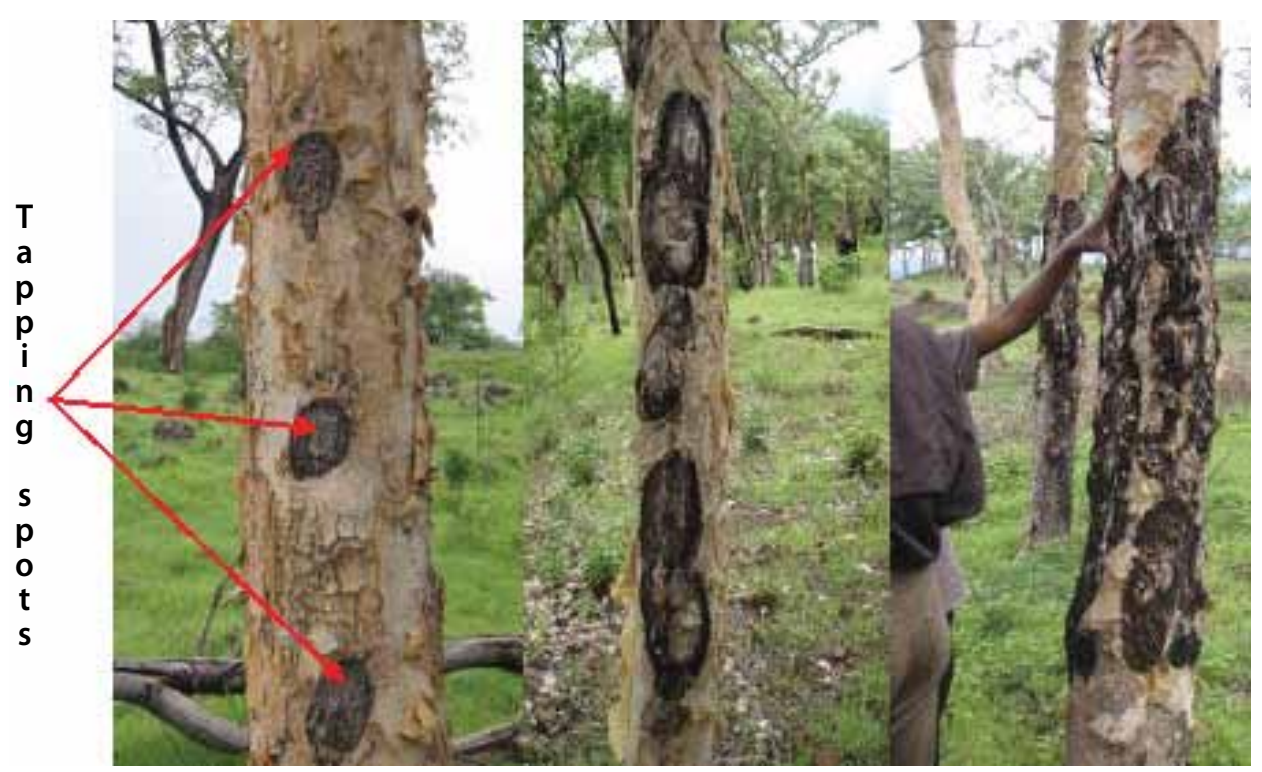

Figure 3.4 Tapping of B. papyrifera after 1 year (left), 2 years (centre) and more than 2 years (right). Photo $\odot$ Mulugeta $L$.

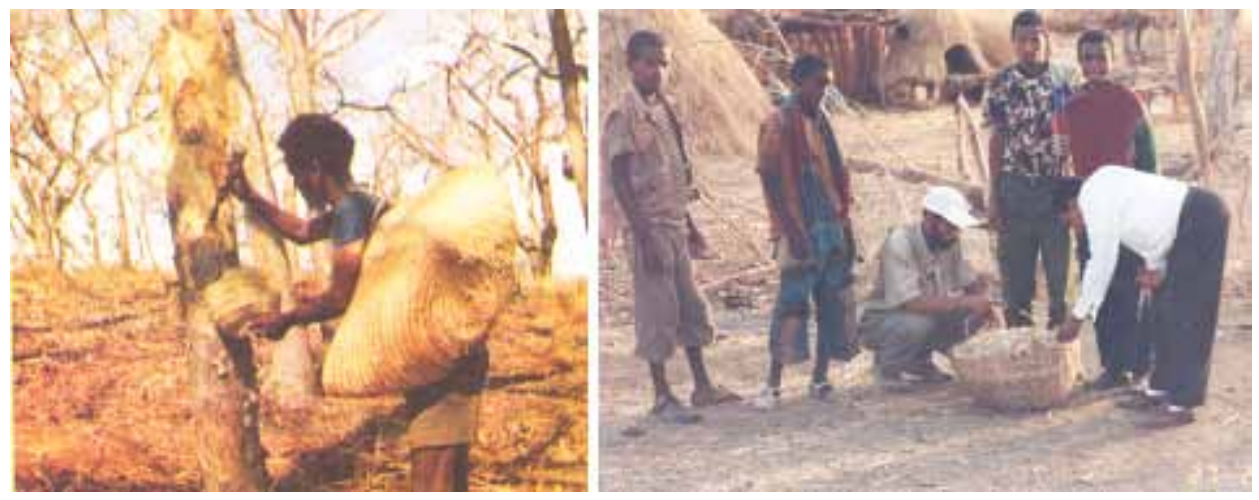

Figure 3.5 Picking of incense tears from stems after maturity and collection vessels used in the north 
year. The first cycle of conventional tapping of B. papyrifera trees begins with wounding the tree stems at 3 spots, at approximately $25-50 \mathrm{~cm}$ apart (Figure 3.4).

Wounds are often made on the eastern and western sides of the tree to allow sufficient exposure to sunlight for quicker drying of gums. However, on big trees, there could be 4 or more tapping spots. Successive tapping cycles involve refreshment of older wounds by removing the bark from the upper edges of the former blaze (wound) and by carving down by $2 \mathrm{~cm}$ of the lower edge, until the whole wound size reaches a width of $10 \mathrm{~cm}$ at the end of the year. Wounding and refreshments continue at intervals of 2-3 weeks until the onset of the rainy season. Usually, a tree is tapped and refreshed 8-12 times during each production season.

Incense tears are manually picked from the stems before refreshment and put into collection vessels made of local materials (Figure 3.5). It is crucial that wounds be refreshed at the right time. If not, old wounds may heal and plants may take longer to reinitiate production of adequate and superior quality resins during the delay. This will also reduce annual yields. It is also important to limit
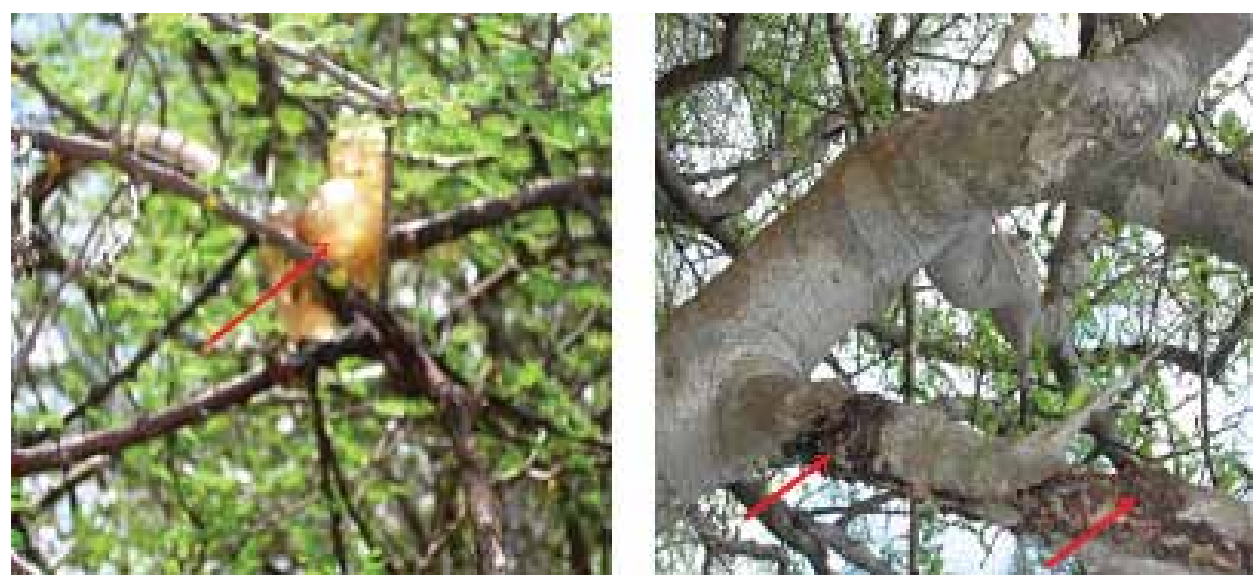

Figure 3.6 (a) Naturally oozing gum of $A$. senegal and (b) incense from B. neglecta Photo $\odot$ Worku (2006).

the number of wounds per tree, as a tree with too many wounds will produce smaller or dusty tears, which are generally regarded as of inferior quality.

\subsubsection{Collection of natural exudates}

Most gums and resins, particularly those produced in the country's south and southeast, are produced from natural exudates (Figure 3.6). Various reasons for the absence of tapping have been suggested. Some studies suggest that as there 
is more than enough supply for the current market demand, there is no need to invest the effort (Lemenih et al. 2003, Worku 2006). Others suggest that farmers are unaware of how to use tapping to produce high-quality gums and resins in good quantities (Fitwi 2000).

In the south of Ethiopia, there are 2 harvest seasons because of the bimodal nature of the rainfall. The production seasons are December-February (following the main rain in October-December) and June-September (following the short rain in March-June). Collectors, who are mostly cattle herders, handpick gums from tree trunks and branches. They include in their collection both tears on the tree and pieces that fall to the ground during picking.

\subsubsection{Organisation of the production system}

Boswellia papyrifera gum production has recognised production systems, with 3 systems commonly observed. In the first system, producing enterprises (private or state) employ and organise the production themselves. Companies hire experienced staff as coordinators and tappers, or they contract coordinators who then employ tappers. Companies provide the workers with all their basic needs such as cooking utensils, clothes, medicines, food, petty cash and tools. The cost of these items is then deducted from workers' wages, with the exception of medicine, which is provided free. The tappers are then organised into a work team commonly known as a squadra, with several squadra organised under a coordinator. Each squadra delivers the olibanum collected to the coordinator, who then delivers it to the company. Final payment, which is based on a rate per piece, is made upon delivery of the olibanum.

The second system is a concession system, in which licensed gum/incenseproducing companies select and contract with individuals who have knowledge and experience in production, as well as the financial means to cover the food and transportation costs of tappers. Depending on the size of the concession site, the concessionaires employ tappers and provide their basic needs. Concessionaires cover all expenses and pay tappers according to a contracted seasonal wage. Concessionaires do not provide tappers with medicine or clothes. The concessionaires ultimately deliver the produce to the companies.

In the third system, farmers or local residents are organised as producer cooperatives and produce gums and resins, which they formally sell to wholesalers and gum exporters. This system, although less common, is growing in importance. With the increasing recognition that locals should have the right to benefit from their nearby resources, there is a growing trend of locals in many producing areas, including Metema, Borana and Tigray, forming local cooperatives for the production and sale of gums and resins. This approach can encourage local people to enhance production of the goods while conserving the resources (Worku 2006, Lemenih et al. 2007). 


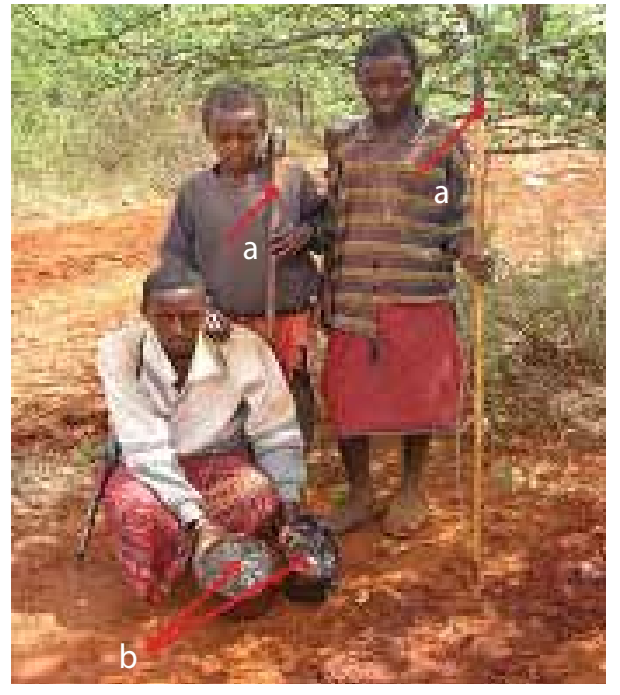

Figure 3.7 (a) Children collecting gum and incense and (b) collection vessel Photo @ Worku (2006)

In the south of the country, there has been no systematic production organisation as such, with the exception of the recently emerging cooperative-based collection system. Farmers, often women and children (Figure 3.7), collect gums and resins that they come across while herding cattle; collection is thus a subsidiary activity. However, when a household's situation is particularly dire, or when market demand is high, men will also get involved in collection and poor households might engage the entire family (Worku 2006). Amounts collected daily or weekly are amassed, or occasionally delivered to local markets and sold to local retailers. Collectors use local items such as old milk containers or sacks for field collection and handling.

Given the erratic climate in the drylands of Ethiopia, the federal and regional governments and other development actors, mainly NGOs, are beginning to explore ways to improve woodland management and to integrate gum and resin production into wider livelihood strategies. Consequently, not only state institutions but also several NGOs are currently engaged in activities related to improving management and exploitation of woodland resources. NGOs are engaged in training, organising and facilitating woodland management and gum and resin production.

There is also growing national interest in intensifying the production of gums and resins (PASDEP 2005), mainly because of their growing contribution to national foreign currency earnings, but also because of rising global demand. For instance, the government strategy for 2005-2010 projected a doubling of gum and resin production and export (PASDEP 2005). 


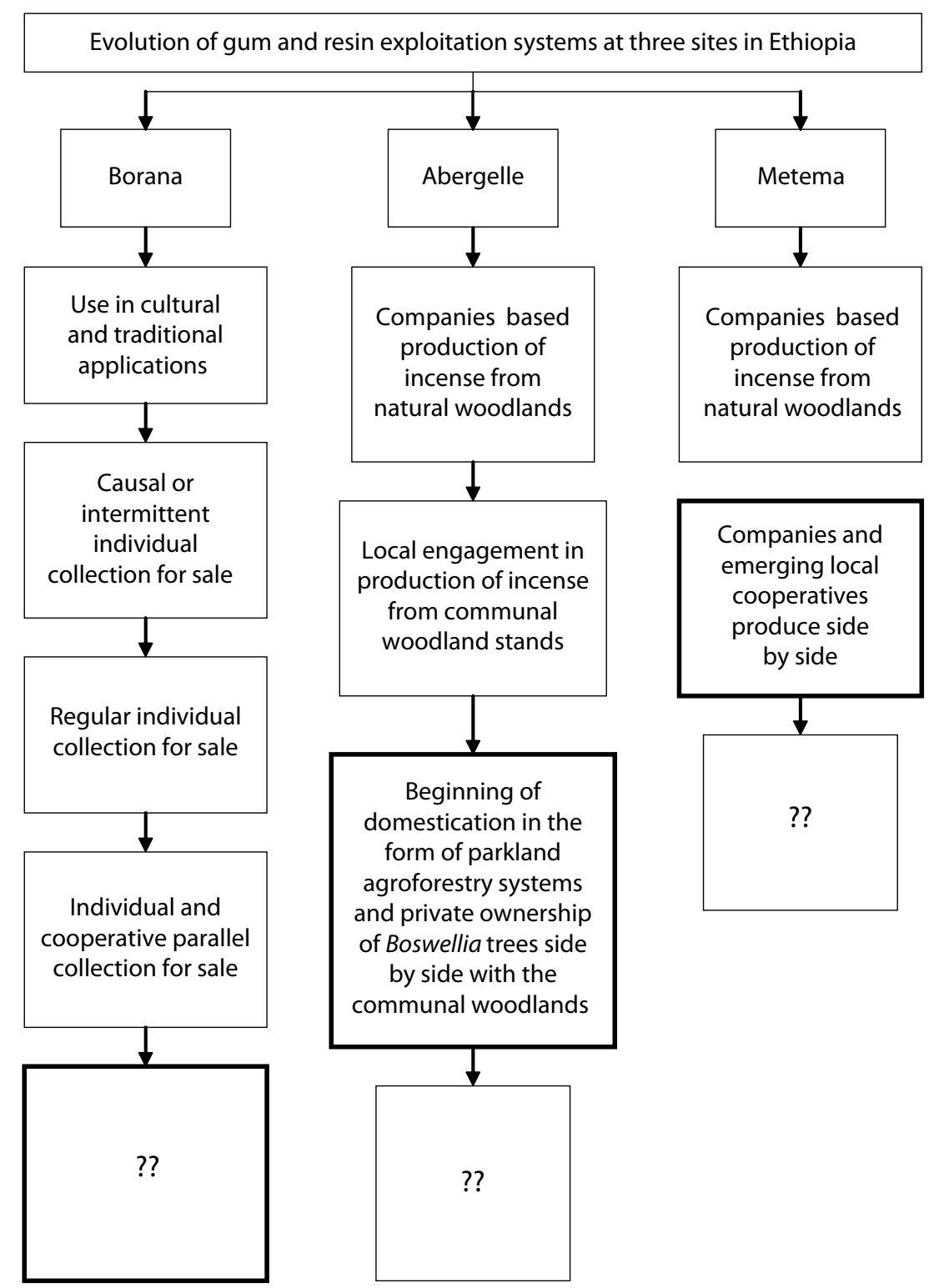

Figure 3.8 Evolution of gum and resin exploitation systems in 3 sites in Ethiopia (boxes with bold borders represent the current system; question marks indicate the future situation)

Alongside these initiatives, new production systems are evolving (Figure 3.8). A rapidly emerging production model in gum and resin exploitation is the cooperative model. This model may come to dominate the country's production system because it may remove obstacles related to: (1) policy of public ownership of land and resources (woodlands or forest), and (2) the arduous and labourintensive nature of gum and resin production. 

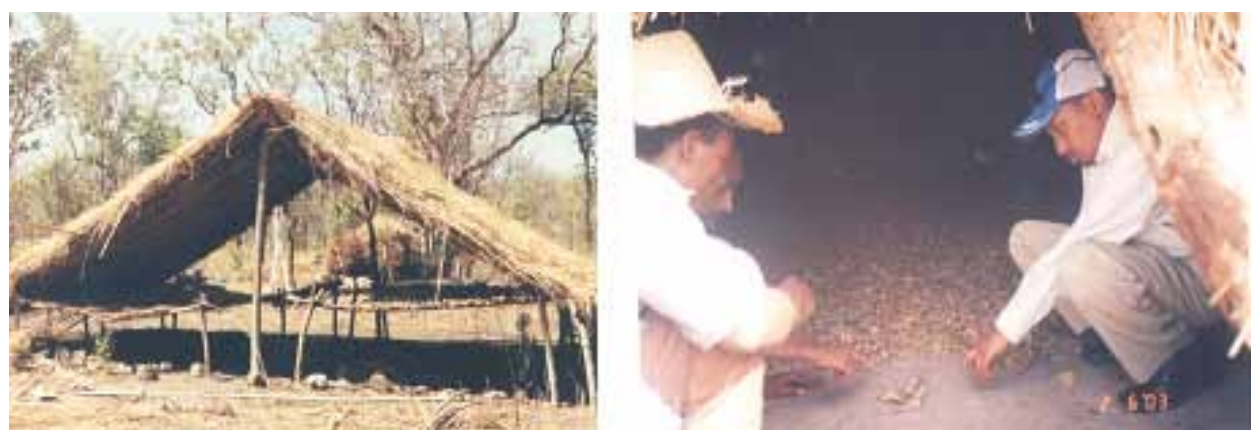

Figure 3.9 Shades constructed for incense seasoning at or near production sites Photo $\odot$ G. Fitwi

Table 3.1 Grades of gum olibanum (Tigray type)

\begin{tabular}{lclc} 
Grade & $\begin{array}{c}\text { Grade } \\
\text { name }\end{array}$ & Description & $\begin{array}{c}\text { Ratio } \\
(\%)\end{array}$ \\
\hline 1st & $1 \mathrm{~A}$ & Size: $\geq 6 \mathrm{~mm}$; white & 22 \\
2nd & $1 \mathrm{~B}$ & Size: $\geq 6 \mathrm{~mm}$; creamy white & 9 \\
3rd & 2 & Size: $4-6 \mathrm{~mm}$ & 11 \\
4th & 3 & Size: $2-4 \mathrm{~mm}$ & 8 \\
5th & $4 \mathrm{~A}$ & Any size; brown ('special') & 19 \\
6th & B & Any size; black ('normal') & 17 \\
7th & 5 & No size limit; powder and bark & 14 \\
\hline
\end{tabular}

\subsection{Post-harvest handling}

Post-harvest handling of gums and resins varies according to the type of gum. In the case of Tigray type gum olibanum, the gums collected from the trees are seasoned in the field by spreading on beds made of local materials under temporary shades (Figure 3.9). Seasoning is essential to avoid clumping of the tears.

\subsubsection{Processing and grading of Tigray type gum olibanum}

After seasoning in the field under shade, the incense is transported to permanent warehouses for further processing. Processing of Tigray type olibanum involves cleaning, sorting and grading of the gums. The entire operation is manual and is usually done by women (see Figure 2.8 in Chapter 2). Grading of olibanum involves sorting the pieces into 7 different grades according size and colour criteria (Table 3.1). 


\subsubsection{Grading myrrh and gum arabic}

Grades for myrrh are the same as those for Tigray type olibanum, except that Grade 1A gums are bright red in colour and Grade 1B gums are brown. No grading system for gum arabic has yet been developed in Ethiopia, even though the country exports quite a substantial amount of clean gum arabic.

\subsection{Quality of gums and resins}

\subsubsection{Chemistry of gums and resins}

A key factor constraining gum and resin trading in Ethiopia is the subsector's failure to guarantee consistent quality. Importers of gums and resins prefer to receive a reliable supply of raw materials of consistent and predictable quality. One of the main practices leading to quality deterioration is adulteration, mostly because of attempts by producer farmers to boost trade volume. Farmers can get away with mixing products of different quality because traders do not have the skills or means to assess the purity of the gums and resins in a trade batch. As most of the gums look similar in terms of colour (e.g. gum arabic of $A$. senegal and gum from A. drepanolobium or A. mellifera), it is difficult to discern them by visual inspection alone. Indeed, farmers seeking to adulterate batches deliberately choose adulterants that are similar to genuine products in colour and texture.

Necessary measures to ensure gum and resin quality are chemical characterisation of each type, testing of each batch and labelling with information on locality and botanical origin. Chemical characterisation is essential because gums from different species, for instance from A. senegal and A. seyal, which are both classified as gum arabic for trading purposes, exhibit characteristics that are intrinsically different. Achieving this form of quality control requires the establishment of commercial test laboratories and industry standards. Farmers and retailers can then be trained not to mix types, but to collect and trade gums and resins from different botanical sources separately. Recognising the differences in gum quality and their end uses (applications) from different species or even varieties is an important part of producing gums and resins that guarantee customer (importers) satisfaction and reassure users regarding safety.

In terms of applications, stringent regulations exist for almost all gums, especially those used as food additives, such as gum arabic (A. senegal origin). Most of these gums are not only tested for chemical composition but also subject to extensive toxicological control by importing countries, organisations and end users. This process demands quality assurance that exceeds simply labelling products with the botanical source and locality. Proper handling of the produce from collection to shipment is crucial to avoid toxicological contaminations. 
To meet these consumer requirements and stimulate strong market demand for gums and resins, supply must comply with set chemical specifications (Seif el Din and Zarroug 1996). Users also want to be able to trace products to their source localities, and to receive guarantees that products are free from any risk.

Some research on chemical characterisation of gums and resins in Ethiopia has been carried out recently, although much remains to be done. Available information on the chemistry of some of the gums and resins from Ethiopia is presented in the following sections.

\subsubsection{Gum arabic}

Gum arabic is a complex arabinogalactan-type polysaccharide exudates of Acacia trees (Sanchez et al. 2002). The exact chemical and molecular structure differs according to the botanical origin of the gum, and these differences are reflected in the analytical properties, functional properties and uses of gum arabic.

Gum arabic is essentially a technical product that is often blended with other gums or materials to produce precise ingredients for food and pharmaceutical applications (Holmes 1997). Vast sums of money go into developing new product lines, thus demanding that ingredients be relatively consistent.

Increasing international pressure for tighter trade specifications, labelling regulations, identity and purity has led to the Revised Specifications (FAO/ WHO-JECFA), which define gum arabic as gum originating from A. senegal or a closely related species, with a specific optical rotation range of $-26^{\circ}$ to $-34^{\circ}$ and a Kjeldahl nitrogen content of 0.27-0.39\% (FAO 1995).

Gum arabic contains neutral sugars (L-rhamnose, L-arabinose and D-galactose) and acids (D-glucuronic acid and 4-methoxyglucuronic acid). It also contains some cations such as calcium, magnesium, potassium and sodium, as well as heavy metals such as lead, copper, cadmium and zinc. Protein is also one of its constituents. However, the exact values and relative proportions of the analytical parameters of gum arabic vary depending on botanical origin and geographical location. Laboratory analysis data for the physico-chemical characteristics of the gum arabic samples from A. senegal are presented in Table 3.2.

Physically, the gum ranges from pale-white to orange-brown in colour, is solid and breaks with a glassy fracture, just like the high-quality gum arabic described in the literature (FAO 1999). The gum is tasteless and odourless. It is readily soluble in water and insoluble in ethanol. The gum's lead content is too low to be detected through laboratory investigation by atomic absorption spectrometer (Table 3.3). As gum arabic is used as a food additive, it must have minimal amounts of heavy metals such as lead, and standards limit the content to less than 2.0 ppm (FAO 1999); gum arabic from A. senegal in Ethiopia's Central Rift 
Table 3.2 Data on the physical and chemical properties of gum arabic from A. senegal in the Central Rift Valley, Ethiopia

\begin{tabular}{|c|c|}
\hline Characteristic & Value \\
\hline Moisture content (\%) & 15 \\
\hline Ash content (\%) & 3.56 \\
\hline Viscosity (centipoise) at 10 (gl-1) & 0.9954 \\
\hline at $7.5(\mathrm{gl}-1)$ & 0.9552 \\
\hline $\mathrm{pH}(25 \%$ sol.) & 4.04 \\
\hline Nitrogen content (\% w/w) & 0.35 \\
\hline Protein $(\% ; \mathrm{N} \times 6.6)^{\mathrm{a}}$ & 2.31 \\
\hline Specific rotation (degree) ${ }^{\mathrm{a}}$ & -32.5 \\
\hline Tannin content (\% w/w) & 0 \\
\hline Gel $(25 \% \text { sol. })^{b}$ & Moderate \\
\hline $\mathrm{Ca}(\mathrm{g} / 100 \mathrm{~g})$ & 0.7 \\
\hline$M g(g / 100 g)$ & 0.201 \\
\hline $\mathrm{K}(\mathrm{g} / 100 \mathrm{~g})$ & 0.95 \\
\hline $\mathrm{Na}(\mathrm{g} / 100 \mathrm{~g})$ & 0.014 \\
\hline $\mathrm{Fe}(\mathrm{g} / 100 \mathrm{~g})$ & 0.001 \\
\hline$P(g / 100 g)$ & 0.6 \\
\hline $\mathrm{Pb}(\mathrm{g} / 100 \mathrm{~g})$ & ND \\
\hline $\mathrm{Mn}(\mathrm{g} / 100 \mathrm{~g})$ & ND \\
\hline $\mathrm{Co}(\mathrm{g} / 100 \mathrm{~g})$ & ND \\
\hline $\mathrm{Cu}(\mathrm{g} / 100 \mathrm{~g})$ & ND \\
\hline $\mathrm{Zn}(\mathrm{g} / 100 \mathrm{~g})$ & ND \\
\hline $\mathrm{Ni}(\mathrm{g} / 100 \mathrm{~g})$ & ND \\
\hline $\mathrm{Cd}(\mathrm{g} / 100 \mathrm{~g})$ & ND \\
\hline $\mathrm{Cr}(\mathrm{g} / 100 \mathrm{~g})$ & ND \\
\hline
\end{tabular}

$\mathrm{ND}=$ not detected; $\mathrm{a}=\mathrm{at} 25^{\circ} \mathrm{C} ; \mathrm{b}=$ based on classifications of no gel, light gel, moderate gel and heavy gel after Chikamai and Banks (1993).

Valley complies with this requirement. The characteristics of gum arabic from the Central Rift Valley were evaluated against several international specifications and compared with gum arabic from well-known sources such as Sudan, Uganda and Kenya. As the assessment presented in Table 3.3 shows, the gum satisfies specifications, and has characteristics similar or superior to gums from Sudan, Kenya and Uganda. 


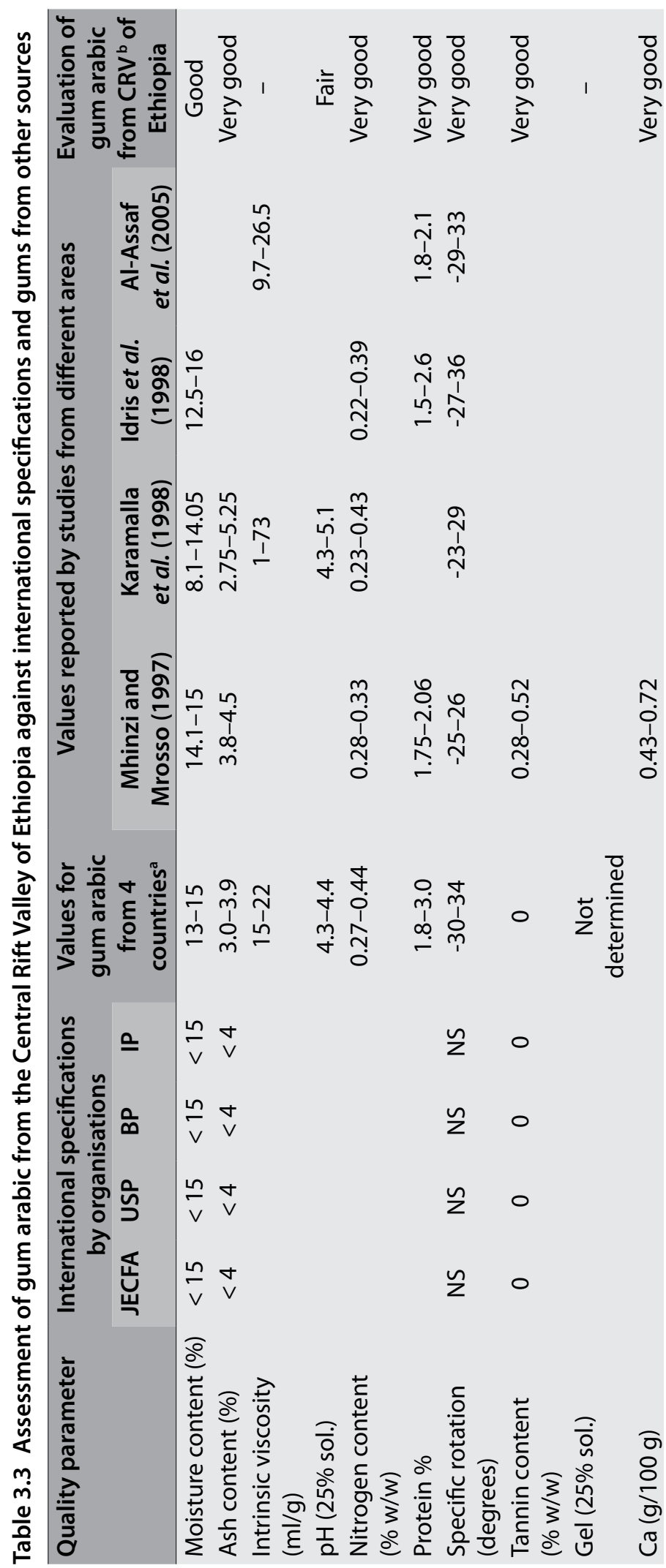




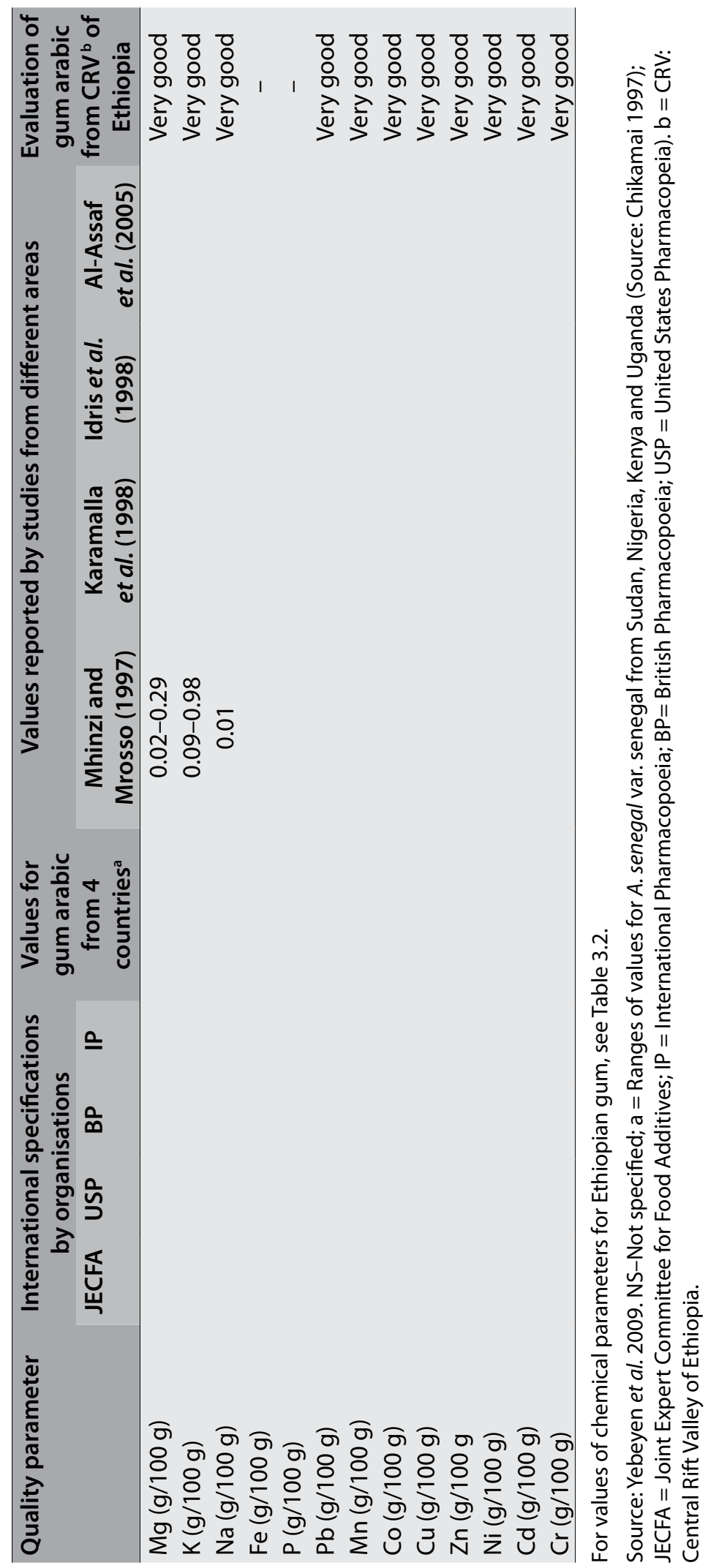




\subsubsection{Aromatic gum resins}

The gum resins (olibanum, myrrh and opoponax) from different species differ in quality because of their chemical composition. The chemical composition of a gum's volatile oil content accounts for its sensory characteristics and determine its fragrance and flavour applications. In other words, most applications of aromatic gum resins depend on their volatile oil content. Nevertheless, nonvolatile constituents are also essential as these account for some biological properties of the products and have several applications such as in medicine (Coppen 2005).

Myrrh contains 57-61\% water-soluble gums, 7-17\% volatile oils, 25-40\% alcohol-soluble resins and 3-4\% impurities. Olibanum is composed of about 5-9\% essential oil and 65-85\% alcohol-soluble resins; the remainder is water-soluble gum or $8-9 \%$ essential oil, $45-50 \%$ resin, $30-40 \%$ gum and 4-5\% impurities. The volatile oils consist of mixtures of mono-, sesqui- and diterpenoids, with the precise composition varying from resin to resin depending on tree species and source locality. The non-volatile components include numerous triterpenoids of the lupan, oleanolic and ursolic acid types. Boswellia resins contain components such as $\alpha$ - and $\beta$-boswellic acids, which are the main active constituents for their medicinal applications.

\subsubsection{Essential oil composition of olibanum}

Olibanum's most important ingredients are its essential oils (volatile oil). The constituents of these volatile compounds in terms of composition and amounts vary between and within species depending on such factors as geographical location, collection time and product handling. Research on the characterisation of essential oils of several Boswellia species has been conducted, but B. papyrifera has received the most attention. Major components in the essential oils of $B$. papyrifera of Ethiopian origin are octyl acetate (50-90\%), a-pinene (6.1\%), camphene (0.6\%), $\beta$-pinene (2.0\%), myrcene (1.7\%), limonene (4.8\%), 1-octanol (5.9\%), linalool (3.6\%), octyl acetate (46.8\%) and geraniol (1.1\%) (Dagne et al. 1997, Dekebo et al. 2002). The essential oils of $B$. neglecta gums are mainly composed of hydrocarbon monoterpenes of $\alpha$-thujene (26\%), a-pinene (20\%), 4 -terpineol (15.7\%), p-cymene (4.5\%), camphor (2.8\%) and $\beta$-pinene (1.9\%) (Dagne et al. 1997).

Information from a recent report on the yield and chemical constituents of different grades of B. papyrifera gum resins is presented in Table 3.4. In all grades, the major component is n-octyl acetate, which accounts for more than $65 \%$, except in Grade 5, which contains around 60\%. The essential oil from the Grade 1 sample is rich with an n-octyl acetate content of $65.25 \%$ followed by an n-octanol content of $4.5 \%$. The table comparing chemical composition indicates that 
Table 3.4 Composition (\%) of the essential oils of different grades of frankincense from B. papyrifera (' $G$ ' = grade)

\begin{tabular}{|c|c|c|c|c|c|c|}
\hline SN & Compound & G-1A & G-2 & G-3 & G-4N & G-5 \\
\hline 1 & a-Thujene & 0.29 & ND & ND & ND & ND \\
\hline 2 & a-Pinene & 2.51 & 1.95 & 0.45 & 2.36 & 1.14 \\
\hline 3 & Camphene & 0.69 & 0.50 & ND & 0.58 & 0.38 \\
\hline 4 & Sabinene & 1.23 & 1.06 & 0.26 & 1.90 & 0.79 \\
\hline 5 & a-Pinene & 0.52 & 0.43 & ND & 0.45 & 0.32 \\
\hline 6 & Myrcene & 0.57 & 0.41 & ND & 0.40 & 0.26 \\
\hline 7 & n-Hexyl acetate & 0.81 & 0.78 & 0.46 & 0.96 & 0.55 \\
\hline 8 & p-Cymene & 0.31 & ND & ND & 0.33 & 0.28 \\
\hline 9 & Limonene & 1.74 & 1.37 & 0.56 & 1.62 & 1.50 \\
\hline 10 & 1,8-Cineole & 1.69 & 1.67 & 0.73 & 1.60 & 1.28 \\
\hline 11 & Trans-ocimene & 1.13 & 1.83 & ND & ND & ND \\
\hline 12 & n-Octanol & 4.51 & 3.63 & 4.55 & 7.46 & 7.75 \\
\hline 13 & Linalool & 2.00 & 1.89 & 1.81 & ND & 1.89 \\
\hline 14 & Endo-borneol & 1.31 & 1.06 & 0.96 & 1.96 & 1.00 \\
\hline 15 & 4-Terpineol & 0.22 & ND & 0.32 & ND & ND \\
\hline 16 & a-Terpineol & 0.47 & 0.44 & 0.46 & 0.51 & 0.42 \\
\hline 17 & n-Octyl acetate & 65.25 & 68.76 & 69.08 & 67.87 & 60.89 \\
\hline 18 & Bornyl acetate & 2.50 & 2.43 & 2.97 & 2.24 & 2.07 \\
\hline 19 & Carvacrol & 0.96 & ND & 0.25 & ND & ND \\
\hline 20 & Unidentified & 0.22 & ND & 0.26 & 0.30 & 0.28 \\
\hline 21 & Neryl acetate & 0.38 & 0.40 & 0.25 & ND & 0.27 \\
\hline 22 & Geranyl acetate & 0.43 & 0.42 & 0.50 & 0.49 & 0.50 \\
\hline 23 & n-Hexyl hexanoate & ND & ND & ND & 0.23 & ND \\
\hline 24 & n-Decyl acetate & 0.50 & 0.42 & 0.57 & 0.50 & 0.53 \\
\hline 25 & Hexyl caprylate & 0.21 & ND & 0.39 & 0.24 & 0.26 \\
\hline 29 & Incensole & 0.59 & 0.58 & 1.25 & 0.28 & 1.40 \\
\hline 30 & Incensole acetate & 2.51 & 3.12 & 5.37 & 1.51 & 5.80 \\
\hline \multicolumn{2}{|c|}{ Total } & 99.03 & 95.57 & 97.94 & 95.59 & 97.63 \\
\hline
\end{tabular}

Retention indices were obtained relative to alkane mixture of $\mathrm{C} 8-\mathrm{C} 30$ and $\mathrm{C} 32$, product of Sigma-Aldrich. ND = not detected. G-4N refers to the category Grade 4 Normal.

current practices of grading and sorting of frankincense have no value in terms of essential oil production. The amount of $n$-octanol found in Grades 4 and 5 is 1.7-2.0 times higher than that found in Grades 1A, 2 and 3. However, variation in the chemical composition of volatile oils may arise due to tapping season (incision time), tapping cycle and geographical location (Fengel 1984). 


\subsubsection{Essential oils of myrrh and opoponax}

The volatile oil of myrrh contains terpenes, sesquiterpenes, esters, aldehydes and alcohols. Seven sesquiterpene hydrocarbons, a furanosesquiterpenoid oil and furanoidiene have been detected in the volatile oil of C. guidotti or opoponax.

\subsection{Quality control}

Factors that affect the quality of gums and resins in Ethiopia include botanical origin, adulteration, collection and handling of the products.

\subsubsection{Gum arabic}

In Ethiopia, gum arabic is produced from A. senegal and A. seyal species. In most cases, the gums of these 2 species are collected, handled, transported and traded separately. However, gums from different varieties are not separated, but are all traded as gum arabic. Adulteration is a major problem affecting the gum arabic trade. Often gums from different species such as A. mellifera and A. drepanolobium are deliberately used as adulterants in gum arabic to boost the trade volume. A relatively rapid means to implement quality control of gum arabic would be to train collectors to avoid adulteration, and to train traders and suppliers to label their gum products with information on variety and locality.

\subsubsection{Gum olibanum and myrrh}

With respect to quality control, frankincense products in Ethiopia are classified as either Tigray type olibanum or other. Tigray type olibanum is produced from B. papyrifera, which is the only Boswellia species growing in the forests of the northern and northwestern lowlands, and hence adulteration with gums and resins from other similar species does not occur. Hence, Tigray type frankincense is the purest in terms of botanical origin. Furthermore, sorting and grading
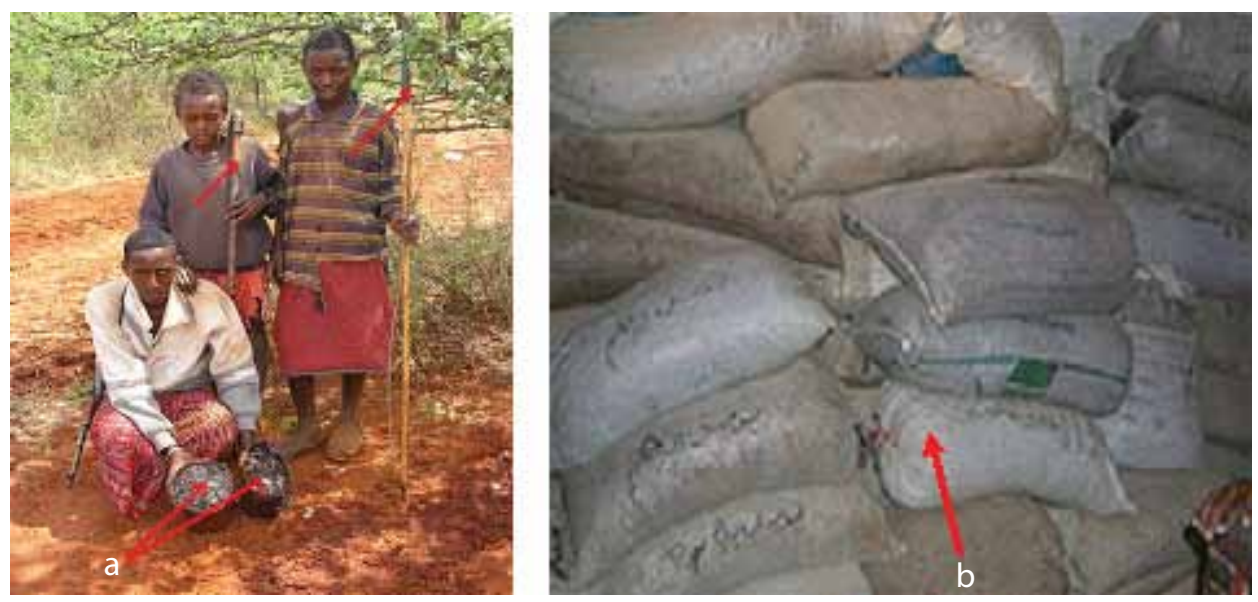

Figure 3.10 (a) Commonly used collection vessels and (b) transportation sacks 
of this frankincense are advanced because of the long history of processing. The granules are sorted, graded and shipped properly, leading to purity of quality grades.

By contrast, Borana and Ogaden type frankincense produced in the south, southeastern and eastern lowlands are characterised by poor quality because of the mixing of gums and resins from different botanical origins. It is not even possible to determine whether these olibanums are different or the exact species of their origin. This is because gums and resins from B. neglecta, B. rivae, $B$. ogadensis and B. microphylla are mixed, either intentionally or unintentionally. Some batches from these regions even contain gums and resins from some Commiphora species because of their similar colour and scent.

Handling and production systems for Borana and Ogaden type olibanums are much less developed than those for Tigray type. Grading is less common and collection is restricted to natural exudates. Quality of natural exudates is compromised by such factors as overexposure to radiation, which bakes the resins and discolours them, and premature collection, which means the gum has a high moisture content, making it clumpy and with loose granulation. Sometimes, fallen granules are collected from the ground, and these tend to be contaminated with soil and other foreign materials. Careless storage and use of inappropriate containers are other common quality-degrading factors affecting all sorts of olibanum products in Ethiopia. Storage and transportation with substances such as petroleum and flammable items are also common. To maintain quality, clean and airtight containers should be used for transport and storage (Figure 3.10), and collected olibanum should not be held in the field under high-temperature conditions. Prolonged storage at high temperatures and in perforated containers can cause the loss of a significant proportion of essential oils, reducing the quality.

\subsection{Challenges related to production and supply}

Numerous constraints and problems, related to management, technical, policy and other interrelated factors, are affecting the production of natural gums and resins in Ethiopia. The major factors challenging gums and resins production are outlined below.

1. Lack of access to roads. Gum- and resin-producing trees tend to grow on rugged and undulating land in remote areas. Inaccessibility or lack of infrastructure such as roads and housing and inadequate transport to potential forest areas always make production and marketing of gums and resins very difficult. Mobilisation of labour force, equipment and other 
supplies as well as collection of gums and transportation to markets are always difficult without adequate road infrastructure.

2. Lack of health facilities. Diseases such as malaria, relapsing fever and water-borne diseases, which frequently affect tappers, are common in the resource base areas. As these areas are remote and inaccessible, lack of access to proper medical treatment often causes tappers to stop work, thus reducing production.

3. Lack of water. As the resource base is in hot and dry areas, workers have high water requirements. However, these areas have a severe shortage of drinking water, and lack of water causes tappers to stop work.

4. Poor food availability. Catering services are extremely low or non-existent. The lack of food availability makes tappers weaker and more susceptible to disease, thus reducing their working capacity and, in turn, production levels.

5. Shortage of labour force. Tappers receive lower wages than for other work, thus encouraging labourers to seek alternative employment.

\section{References}

Al-Assaf, S., Phillips, O.G. and Williams, A.P. 2005 Studies on Acacia exudate gums. Part I: the molecular weight of Acacia senegal gum exudates. Food Hydrocolloids 19: 647-660.

Chikamai, B.N. 1997 Production, markets and quality control of gum arabic in Africa: findings and recommendations from an FAO project. In: Mugah, J.O., Chikamai, B.N., Mbiru, S.S. and Casadei, E. (eds) Conservation, management and utilization of plant gums, resins and essential oils. Proceedings of a regional conference for Africa. Nairobi, Kenya, 6-10 October.

Chikamai, B.N. and Banks, W.B. 1993 Gum arabic from Acacia senegal (L) Willd in Kenya. Food Hydrocolloids 7: 521-534.

Coppen, J.J.W. 2005 Overview of international trade and markets. In: Chikamai, B. and Casadei, E. (eds) Production and marketing of gum resins: frankincense, myrrh and opoponax, 5-34. NGARA publication series 5. Network for Natural Gums and Resins in Africa, Kenya, Nairobi.

Dagne, E., Dekebo, A., Desalegn, E., Bekele, T., Tesso, H. and Bisrat, D. 1997 Essential oils from frankincense, myrrh and other plants of Ethiopia. Paper presented at the Regional Conference for Africa on the Conservation, Management and Utilisation of Plant Gums, Resins and Essential Oils. Nairobi, Kenya, 6-10 October. 
Dekebo, A., Dagne, E. and Sterner, O. 2002 Furanosesquiterpenes from Commiphora sphaerocarpa and related adulterants of true myrrh. Fitoterapia 73(1): 48-55.

Fitwi, G. 2000 The status of gum arabic and resins in Ethiopia. In: Report of the meeting of the network for natural gums and resins in Africa (NGARA): Proceeding 29-31 May, Nairobi, Kenya.

Food and Agriculture Organization of the United Nations (FAO) 1995 Role of Acacia species in the rural economy of dry Africa and the Near East. In: Wickens, G.E. (ed.) FAO conservation guide 27. FAO, Rome.

Food and Agriculture Organization of the United Nations (FAO) 1999 Compendium of food additive specifications addendum 7. Food and nutrition paper, no. 52. Add. 7. Joint FAO/WHO Expert Committee on Food Additives 53rd Session Held in Rome, 1-10 June 1999. FAO, Rome.

Gebremedhin, T. 1998 Boswellia papyrifera (Del.) Hochst from Western Tigray opportunities, constraints and seed germination responses. Master's thesis, Swedish University of Agricultural Sciences, Sweden.

Holmes, I. 1997 Gum arabic-life in a saturated market. In: Mugah, J.O., Chikamai, B.N., Mbiru, S.S. and Casadei, E. (eds) Conservation, management and utilization of plant gums, resins and essential oils. Proceedings of a regional conference for Africa. Nairobi, Kenya, 6-10 October.

Idris, O.H.M., Williams, P.A. and Phillips, G.O. 1998 Characterization of gum from Acacia senegal trees of different age and location using multidetection gel permeation chromatography. Food Hydrocolloids 12: 379-388.

Karamalla, K.A., Siddig, N.E. and Osman, M.E. 1998 Analytical data for Acacia senegal var. senegal gum samples collected between 1993 and 1995 from Sudan. Food Hydrocolloids 12: 373-378.

Lemenih, M., Abebe, A. and Olsson, M. 2003 Gum and resin resources from some Acacia, Boswellia and Commiphora species and their economic contributions in Liban, South-east Ethiopia. Journal of Arid Environments 55: 465-482.

Lemenih, M., Feleke, S. and Tadesse, W. 2007 Constraints to smallholders production of frankincense in Metema district, north-western Ethiopia. Journal of Arid Environments 72: 393-403.

Mhinzi, G.S. and Mrosso, H.D.J. 1997 Chemotaxonomic aspects of gum exudates from some Acacia species. In: Mugah, J.O., Chikamai, B.N., Mbiru, S.S. and Casadei, E. (eds) Conservation, management and utilization of plant gums, resins and essential oils. Proceedings of a regional conference for Africa, Nairobi, Kenya, 6-10 October.

Plan for Accelerated and Sustained Development to End Poverty (PASDEP) 2005 Ethiopia: building on progress: a plan for accelerated and sustained development to end poverty 2005/06-2009/10. Ministry of Finance and Economic Development, Addis Ababa, Ethiopia.

Sanchez, C., Renard, D., Robert, P. and Schmitt, C. 2002 Structure and rheological properties of Acacia gum dispersions. Food Hydrocolloids 16: 257-267. 
Seif el Din, A. and Zarroug, M. 1996 Production and commercialization of gum arabic in Sudan. In: Domestication and commercialization of non-timber forest products in agroforestry systems. Non-wood forest products 9. Food and Agriculture Organization of the United Nations, Rome. http://www.fao. org/docrep/w3735e/w3735e00.htm [17 January 2011].

Taib, A. 1982 The Swiss, Italian and Finnish markets for Ethiopian gum olibanum. Programme for Development Cooperation, market research report no. 5. Helsinki School of Economics, Helsinki, Finland.

Worku, A. 2006 Population status and socio-economic importance of gum and resin bearing species in Borana lowlands, southern Ethiopia. Master's thesis, Department of Biology, Addis Ababa University, Addis Ababa, Ethiopia.

Yebeyen, D., Lemenih, M. and Feleke, S. 2009 Characteristics and quality of gum arabic from naturally grown Acacia senegal (Linne) Willd. trees in the Central Rift Valley of Ethiopia. Food Hydrocolloids 23: 175-180. 



\section{Chapter 4}

\section{Value-added processing and marketing of gums and resins}

Sisay Feleke' and Samuel Melaku²

\subsection{Introduction}

Natural gums are important for 2 main reasons. First, they have a wide range of industrial applications, from confectionery to cosmetics to atomic reactors, and second, gum production is a farmer-based industry providing income to farmers when it is needed most. Thus, the subsector performs an important function in terms of food security and income generation for people living in production regions. Export earnings from the subsector are important for a country with limited exports. The commercial activity is creating employment opportunities and income for an estimated 25 000-35 000 Ethiopians annually. Of these, about $90 \%$ are believed to be poor, rural residents who seasonally participate in collecting, tapping, cleaning and grading activities. The average annual cash income generated per individual from tapping and collection of gums and resins is estimated to be 172 USD and that from cleaning and grading is estimated to be 165 USD. This forms $42 \%$ of annual household income.

Even though Ethiopia is one of the few countries with large frankincense and myrrh resources and is a leading exporter, the country has neither industrial uses or applications nor value-added processing for any of the gums and resins produced there. There is no doubt that introducing value-added processing of the resources, rather than merely supplying raw gum and resin materials, would produce greater benefits for exporting countries such as Ethiopia. This particularly applies given that relatively large proportions of the apparently low grades of gums and resins are left for non-industrial local uses. Introducing value-added processing would enable Ethiopia to realise the full benefits of its gum and resin resources.

1 Forest Product Processing and Utilization Center, FRC/EIAR, Ethiopia

2 Natural Gum Production and Marketing Enterprise, Addis Ababa, Ethiopia 
Despite the huge potential, Ethiopia is not making useful gains from the subsector. Numerous problems constrain marketing of gum and resin products, including fluctuating supply of the products in terms of both quantity and quality, lack of appropriate usage and marketing policies, inadequate infrastructure and poor market accessibility. In general, knowledge about market performance and market-development linkages in the subsector is limited.

\subsection{Industrial application and local use of gums and resins}

\subsubsection{Gum arabic}

Gum arabic is a unique, extensively used natural product with several industrial applications. It is used in pharmaceutical preparations, confectionery, sweetmeats and cosmetics, and for the production of products such as ink, paint, paper, matches, ceramics, water-colours, wax polishes, liquid gum, and to dress fabrics, giving lustre to silk and crepe, thickening colours and mordants in calico printing (FAO 1988). Gum arabic is highly valued for numerous applications because of its combination of high solubility in water and low viscosity.

Gum arabic is used in the food industry to fix favours, to prevent the crystallisation of sugar in confectionery products, as an emulsifier and as a stabiliser in frozen dairy products; its viscosity and adhesive properties have been found to be useful in baked goods, and as a foam stabiliser and clouding agent in beer. Despite increased demand for convenient foods as part of a modern lifestyle, growing awareness of the relationship between food and health has increased demand for high-fibre, low-fat food products. These factors have resulted in considerable interest in the use of hydrocolloids including various gums, modified starches and gelatin in foods and this is expected to continue in the future (Casadei 1997).

In the pharmaceutical industry, gum arabic is used as a stabiliser for emulsions, as a binder and coating for tablets and as an ingredient in cough drops and syrups (Coppen 1995). In modern pharmacy, it is commonly employed as a demulcent in preparations designed to treat diarrhoea, dysentery, coughs, throat irritation and fevers. It serves as an emulsifying agent and gives viscosity to powdered drug materials; it is used as a binding agent in making pills and tablets, particularly cough drops and lozenges. In recent years, it has been used in a medicine to treat kidney problems.

Gum arabic is used in cosmetics as an adhesive for facial masks and powders, and to give a smooth feel to lotions. Industrially, gum arabic is applied as an adhesive, as a protective colloid and safeguarding agent for inks, sensitiser for lithographic plates, coating for special papers, sizing agent for cloth to give body to certain 
fabrics and coating to prevent metal corrosion. Gum arabic is also used in the manufacture of matches and ceramics (Cossalter 1991). Powdered, reddishbrown gum exudate mixed with fat or grease is used to massage the body. Fresh gum exudate is used as a depilatory. A solution of gum, drunk on an empty stomach, is used to relieve chest pains. The eating of gum is reputed to strengthen the stomach muscles. However, excessive eating of gum can cause flatulence and some discomfort. Gum is highly nutritious, $175 \mathrm{~g}$ being sufficient to support an adult for 24 hours (Coppen 1995).

\subsubsection{Gum olibanum and myrrh}

Oleo-gum resins of olibanum, myrrh and opoponax are widely used in perfumery, food industries and pharmaceuticals. Both myrrh and frankincense are highly valued for their fragrance and are common ingredients in incense, perfumes and potpourris, soaps, detergents, creams and lotions; they are also often included in meditation blends, as they strengthens the psyche and aid in deepening the meditative state (Coppen 1995). Frankincense is a favoured ingredient for potpourris, as it is known to hold its fragrance for a very long time - some even say indefinitely (Tucker 1986). In addition to its fragrance, it is noted to have some value as a fixative in perfumes and potpourris. Perfumers use it as an absolute (by alcohol extraction), oil or resinoid (by hydrocarbon extraction) and include it in oriental bases, ambers, powder perfumes, floral perfumes, citrus colognes, spice blends, violet perfumes, male fragrances, soaps, lotions, creams and others (Leung 1980:241-242 Tucker 1986, Coppen 1995). It is also used in the formulation of many modern perfumes including Replique by Colonia, Me! by Frances Denney, Mennen Millionaire by Mennen, Nino Cerruti Pour Homme by Uniperf, Onna by Gary Farn and Sculpatura by Jovan (Tucker 1986).

The odour of myrrh is described as warm-balsamic, sweet, somewhat spicyaromatic, sharp and pungent when fresh. Hence, perfumers use myrrh as an absolute, oil or resinoid, and in oriental-spicy bases, chypres, woody bases, forest notes, pine fragrances and others (Tucker 1986). Myrrh is included in the formulation of several modern perfumes including Fidji by Guy Laroche, Onna by Gay Farn and Volcan d'Amour by Diane von Furstenburg (Fragrance Foundation 1983). The resinoids are also used in soaps and detergents; users include multinationals such as Unilever, Proctor and Gamble (Farah 1994).

Frankincense and myrrh products also have a wide range of other industrial uses, such as in beverages, candies, chewing gums, confectioneries, gelatins, nut products, puddings and canned vegetables (Coppen 1995). Typical applications include as adhesive thickeners, thickeners, stabilisers, flavour fixatives and emulsifying agents in food products, for clarification in beverages and as release agents for rubber products. 
Both frankincense and myrrh have modern pharmacological applications for the treatment of diseases, mostly as diagnosed and practised in traditional therapies. In Germany, myrrh gum resin and myrrh tincture are included in the official German Pharmacopoeia (Wichtl and Bisset 1994, Braun et al. 1997). The tincture is used as a mono-preparation, and also as a component of various dental remedies and mouthwashes, toothpaste, ointments, paints and coated tablets, as well as in the applications of paint, gargle and/or rinse in dentistry. For example, the product Merfluan is an effervescent dentifrice salt with myrrh (Mielck 1970). In paediatric medicine, tincture of myrrh is used in Germany to treat oral candidiasis (thrush), which is common in infants (Schilcher 1997).

Myrrh is officially in the United States Pharmacopeia (USP) and National Formulary (Leung and Foster 1996). In the United States, it is used as an aromatic astringent mouthwash. In tincture form, myrrh gargles and mouthwashes are considered useful in treating sore throats or other oral mucosal or gingival irritations (Tyler 1993). The British Herbal Pharmacopoeia and European Pharmacopoeias recognise the pharmaceutical applications of myrrh (Coppen 2005). The British Herbal Compendium indicates the use of myrrh tincture as a gargle to treat pharyngitis and tonsillitis (Bradley 1992). In France, its topical use is approved for the treatment of small wounds, for nasal congestion from common cold and for local application as an anodyne to treat infections of the buccal cavity and the oropharynx (Bradley 1992, Bruneton 1995). The Merck Index reported its therapeutic action as carminative and astringent (Budavari 1996). Myrrh has also been shown to have disinfecting, deodorising and granulation-promoting properties (Wichtl and Bisset 1994).

In Chinese medicine, myrrh from C. myrrha (C. molmol) is used as a component in many patent medicines, including bu-gu-zhi-wan (psoralea pills) and zhi-wan (haemorrhoid pills), as well as various topical plaster adhesives and lotions, including die-da-yao-jing (traumatic injury medicine essence) (Fratkin 1986:125-134, 142-148; Yen 1992). Myrrh is also used as an insecticide, especially against termites, and as a mosquito repellent when blended as incense sticks. Several recent pharmaceutical studies on the resins of many Commiphora and Boswellia species have reported their wide applications. A constituent of the resin from $C$. rostrata has repellent effects against the maize weevil, and the gum resin of B. papyrifera and C. africana affects 3 insect pests of economic importance, by leading to the morphological malformation of adults and pupae, reducing the emergence of adults and increasing insect mortality rate (Karamalla 1997). Recently, 2 compounds in myrrh, furanoeudesma-1,3-diene and curzarene, were reported to have pronounced pain-relieving (analgesic) properties, as claimed by traditional therapies (Freese, 1996). Myrrh's antiinflammatory (Duwiejua et al. 1993), antipyretic and antihistaminic (Tariq 
et al. 1985), hypolipidaemic (Malhotra et al. 1977, Michie and Cooper 1991), hypocholesterolaemic, anti-atherosclerotic (Lata et al. 1991, Michie and Cooper 1991), anti-arthritic (Duwiejua et al. 1993), anti-gastric ulcer and cytoprotective (Al-Harbi et al. 1997), anti-tumour (Qureshi et al. 1993, Al-Harbi et al. 1994), smooth muscle relaxing (Claeson et al. 1991), anti-schistosomiasis (Massoud et al. 1998) and anti-fascioliasis (Massoud et al. 2001) properties have been verified, as has its usefulness in paediatric and blood lipid remedies in children (Michie and Cooper 1991) and lack of toxic side effects (Rao et al. 2001, Massoud et al. 2001). Myrrh also has astringent properties and has a soothing effect on inflamed tissues in the mouth and throat. Studies have also examined the anti-cancer potential of myrrh resin (Al-Harbi et al. 1994, Dolara et al. 1996). In addition to its antiseptic and expectorant abilities, myrrh destroys putrefaction in the intestines and prevents the absorption of toxins in the blood. It also stimulates blood flow to the capillaries and promotes menstruation (Frawley and Lad 1986).

The resinous portion of myrrh carries significant anti-inflammatory, antirheumatic and hypocholesterolaemic/hypolipidaemic activity. It is known to contain a rich source of steroids, which may find use as an alternative raw material for the synthesis of important corticosteroid drugs such as dexamethasone and betamethasone (Bhatt et al. 1989). For instance, a preparation by the name 'Guglip' developed from guggal (gum resin from C. wightii) by the Central Drug Research Institute, Lucknow, India is reported to possess hypolipidaemic activity equivalent to that of Clofibrate (ethyl p-chlorophenoxyisobutyrate), the drug of choice at the time of the relevant study (Bhatt et al. 1989). It was anticipated that with the discontinuation of Clofibrate in the USA because of its toxic manifestations, there would be ample scope to introduce Guglip on a commercial scale (Bhatt et al. 1989).

Frankincense has also been employed for medicinal purposes since antiquity. Various civilisations (including Egyptian, Greek, Roman, Chinese, Arabic and Indian) used it as an anti-catarrhal, anti-depressant, antiseptic, anti-tumour, diuretic stimulant, emmenagogue, expectorant, immune-system stimulant and sedative, as well as for treatment of cough and asthma (Wahab et al. 1987). Today, it is used against asthma, ulcers, aging, allergies, snake and insect bites, bronchitis, cancer, carbuncles, catarrh, colds, coughs, diarrhoea, headaches, haemorrhage, herpes, high blood pressure, inflammation jaundice, laryngitis, meningitis, nervousness, prostate, pneumonia, scarring sciatic pain, soars, spiritual awareness, staph, strep, stress, syphilis, tuberculosis, typhoid, wounds and warts and to strengthen the immune system (Leung and Foster 1996).

Pharmacological applications have recently justified the use of frankincense for its anti-tumour and anti-carcinogenic (Huang et al. 2000), anti-inflammatory (Shao et al. 1998, Safayhi et al. 2000, Krieglstein et al. 2001), anti-proliferative (Glaser et al. 1999, Hoernlein et al. 1999), anti-chronic colitis (Gupta et al. 2001) 
and anti-bronchial asthma (Gupta et al. 1998) effects, as well as for anti-human leukaemia HL-60 cells and the DNA, RNA and protein synthesis in HL-60 cells (Shao et al. 1998). Controlled, double-blind studies have shown that Boswellia extracts are very helpful for ulcerative colitis (Singh and Atal 1986). The antiinflammatory effects of treatment with Boswellia extract or AKBA (acetyl-11keto- $\beta$-boswellic acid) in experimental ileitis in rats are comparable to those achieved by treatments with standard drugs for inflammatory bowel disease such as prednisolone and sulfasalazine (Yamada et al. 1993). A pilot study in human ulcerative colitis of the same procedure reported fewer side effects from the treatment with Boswellia extract than from steroids (Gupta et al. 1997). Boswellia extract was found to inhibit pro-inflammatory mediators in the body, such as leukotrienes (Singh and Atal 1986) and, in contrast to non-steroidal anti-inflammatory drugs, long-term use of Boswellia extracts does not lead to irritation or ulceration of the stomach (Gupta et al. 2001).

The liquid part of freshly collected Boswellia oil is very similar to turpentine oil obtained from Pinus species, and readily dissolves colophony, dammar and other resins (Murthy and Shiva 1977). The higher iodine number of the volatile oil, which consists mainly of dextropinene mixed with L-pinene of Boswellia gum, indicates its suitability for the paint and varnish industry, and can be a substitute for pine turpentine oil (Murthy and Shiva 1977).

\subsection{Value-added processing and implications}

Gums and gum resins have various industrial and local applications because of their chemical constituents and physical properties. At the final destination or application sites, these gums and resins are processed and reprocessed into their various constituents. This processing multiplies their value and economic returns. For instance, gum resins such as olibanum, myrrh and opoponax are processed for their essential oils, which are regarded as important industrial raw materials. By extracting the essential oils and further processing, the complex mixture of the chemical compound can be separated into its individual compounds, which are used in several applications. During this process, as necessary, a particular flavour or aroma can be amplified, eliminating unwanted fractions and concentrating on desired ones. Certain chemicals can also be separated in groups by physical or chemical methods, and thus a diversity of products can be generated from just a single raw material.

Most commonly used essential oils in several industrial applications are derived from plant materials. Oils can be extracted in several ways, including the following. 
- Expression mechanical flow. An Indian type olibanum produces essential oils in such a way that the exudate collected from the tree in a semi-viscous state is left in the shade for the oil to flow from the resin.

- Solvent extraction. Low boiling organic solvents are used to extract the essential oil and other non-polar compounds or liquid gases such as $\mathrm{CO}_{2}$. This method requires further processing of essential oils and resinous products. For example, pine oils, from the foliage and resins of pine trees, are produced in this manner.

- Vacuum distillation. This involves isolation of the oil under vacuum pressure.

- Stem/hydro distillation. This method results in pure production of the essential oils, which float over the condensate.

Processing of frankincense for the production of essential oil is simple and does not require any special skills. Gum olibanum is added to a proportion of water and distilled from the apparatus at boiling point. The steam created by dissolving or vaporising the volatile oils from the frankincense is allowed to condense; the condensation is collected in a basin where the oil floats on top of the water. This technology can be adopted to the farmer level using prototype apparatuses. By doing so, more returns can be fetched.

\subsection{Advantages of value-added processing}

There are several advantages of value-added processing, as follows.

Optimisation of profit gains. Essential oils have a higher market value than raw gum resins. One kilogram of frankincense collected from B. papyrifera costs about 2-3 USD on the international market. However, this same amount can yield the equivalent of $0.7-1 \% \mathrm{w} / \mathrm{w}$ essential oil (i.e. $70-100 \mathrm{gm} / \mathrm{kg}$ ), which can be sold for up to 10 times as much.

Increased tradable quantity and foreign currency earnings. Producing essential oils does not require sorting and grading. Furthermore, as chemical evaluation of the different grades has not revealed any significant difference in terms of chemistry or yield, all grades can be used for essential oil production; thus, greater net exports can be achieved. Furthermore, by avoiding the labour-intensive grading and sorting activities, producing essential oils can reduce processing costs and increase profit margins.

Transport-related advantages. Essential oils are lightweight products compared with raw gums and resins. If oils are extracted at the production site, the finished product can be easily and cheaply transported. Ethiopia is a landlocked country, and ports are far from the production and processing centres. This is one cause of the subsector's high production costs and low 


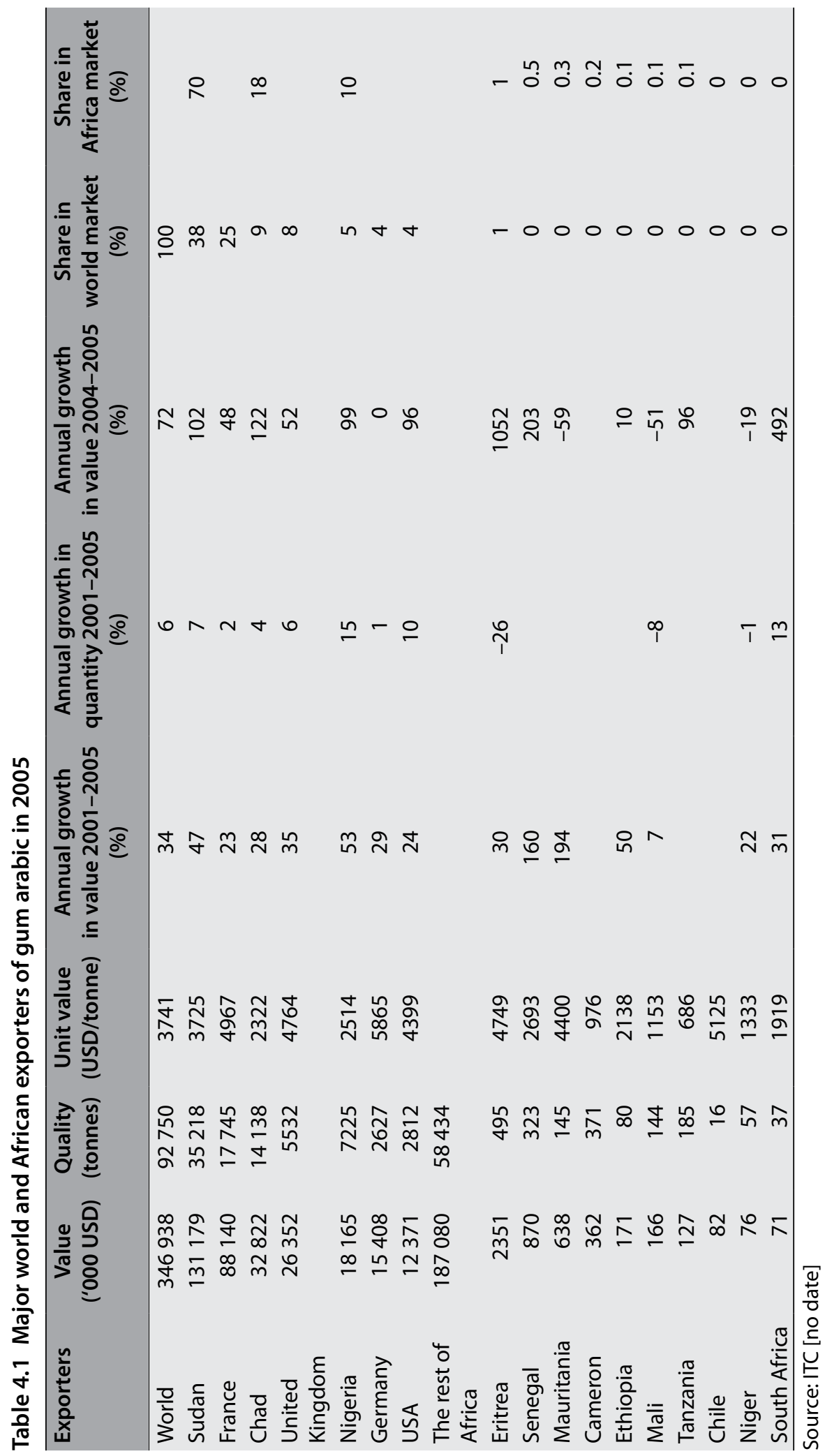




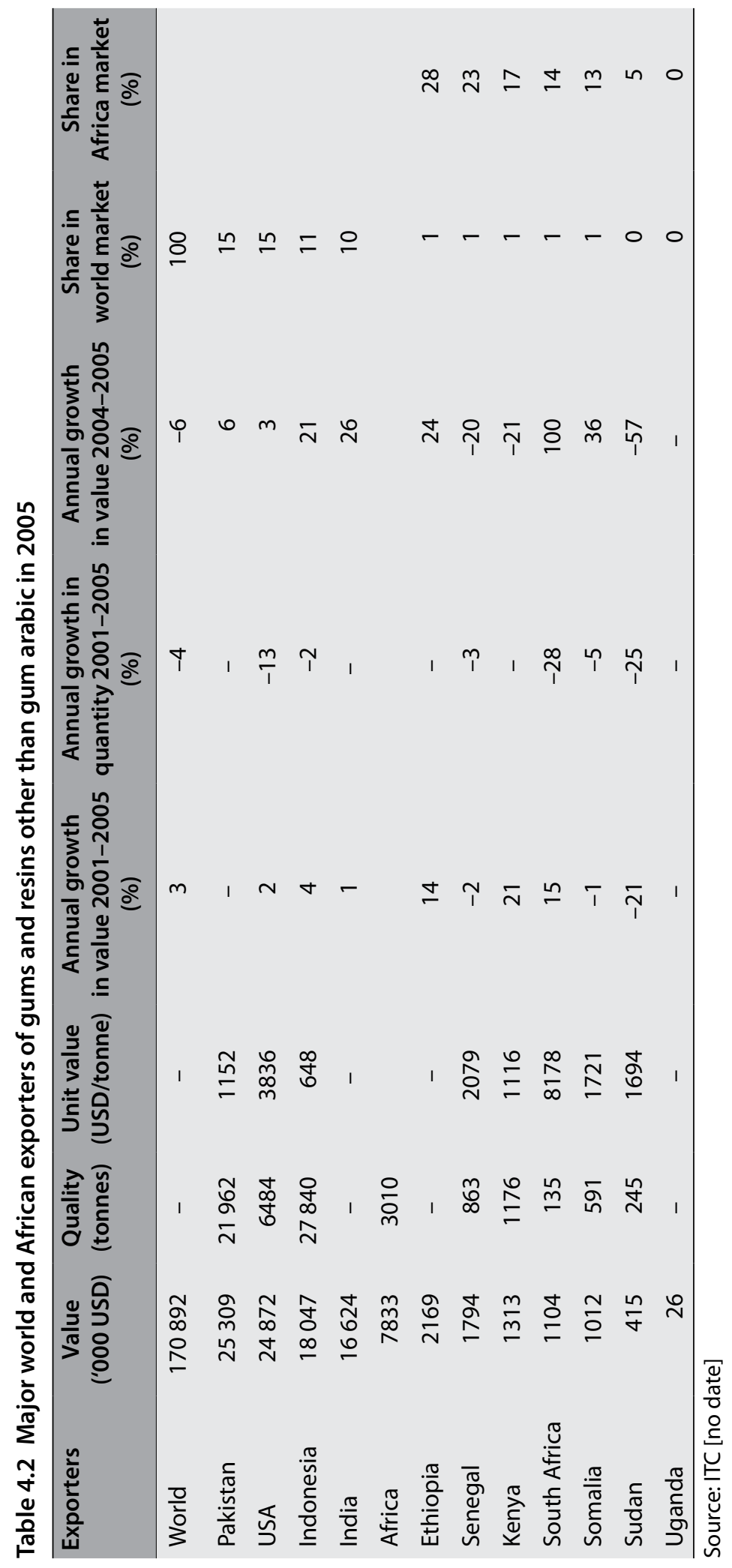


Table 4.3 Natural gum and resin exports from Ethiopia by destination in 2005/06 Ethiopian Fiscal Year

\begin{tabular}{|c|c|c|c|}
\hline Country & Weight (kg) & Value (USD) & Share (\%) \\
\hline United Arab Emirates & 543404 & 986390 & 18.39 \\
\hline Germany & 413905 & 773850 & 14.43 \\
\hline Tunisia & 316976 & 721422 & 13.45 \\
\hline China & 672810 & 505836 & 9.43 \\
\hline Greece & 212120 & 318330 & 5.94 \\
\hline Djibouti & 227782 & 228978 & 4.27 \\
\hline Guatemala & 132984 & 205926 & 3.84 \\
\hline Yemen & 107278 & 174161 & 3.25 \\
\hline Egypt & 87165 & 165424 & 3.08 \\
\hline France & 75000 & 136594 & 2.55 \\
\hline Sudan & 145400 & 136500 & 2.55 \\
\hline Saudi Arabia & 70000 & 135930 & 2.53 \\
\hline Turkey & 60000 & 132688 & 2.47 \\
\hline Taiwan & 60000 & 128324 & 2.39 \\
\hline Belgium & 62318 & 115958 & 2.16 \\
\hline Dubai & 49500 & 98078 & 1.83 \\
\hline India & 46000 & 76650 & 1.43 \\
\hline Sierra Leone & 64000 & 71200 & 1.33 \\
\hline Italy & 32300 & 56964 & 1.06 \\
\hline Netherlands & 46470 & 56356 & 1.05 \\
\hline Cuba & 32300 & 55200 & 1.03 \\
\hline Peru & 14250 & 29925 & 0.56 \\
\hline Hong Kong & 30000 & 20700 & 0.39 \\
\hline United Kingdom & 16974 & 17754 & 0.33 \\
\hline Israel & 10497 & 12207 & 0.23 \\
\hline Tanzania & 105 & 1350 & 0.03 \\
\hline United States of America & 60 & 442 & 0.01 \\
\hline Canada & 40 & 40 & 0.00 \\
\hline Total & 3529338 & 5363176 & 100.00 \\
\hline
\end{tabular}

Source: Ministry of Trade and Industry (2006) 
profit margins, which can be addressed by value-added processing such as essential oil production.

Raw materials for local market and local industries. Processing of some of the gums and gum resins will provide opportunities for import substitution. Some products can be used in local pharmaceuticals, detergents/soaps and other industries, which currently rely for most of their raw materials on imported items.

\subsection{Trade and marketing of gums and resins}

\subsubsection{Exports}

According to recent data, both the value and the volume of gum exports from Ethiopia are increasing. Gum and resin exports contribute about $0.54-0.73 \%$ of the country's total export revenue. Of the 4 export products in this subsector frankincense, myrrh, gum arabic and opoponax - frankincense, typically that of Tigray type frankincense accounts for $91 \%$ of the value and $93 \%$ of the quantity.

Despite the huge potential for gum arabic production in Ethiopia, exports of gum arabic remain negligible - close to $0 \%$ at world scale and only $0.1 \%$ in Africa (Table 4.1). However, the value of Ethiopian gum arabic alone in the world market grew by $50 \%$ and $10 \%$ for the periods 2001-2005 and 2004-2005, respectively. If the estimated potential of 4996 tonnes - or even half of it - were produced and exported, Ethiopia could increase its gum arabic exports to be $3-4 \%$ of the world total.

In terms of the market for gums and resins other than gum arabic, Ethiopia has $1 \%$ of the world market and $28 \%$ of Africa's export trade. Ethiopia is thus Africa's leading exporter of natural gums and resins other than gum arabic (Table 4.2). Although Ethiopia has only $1 \%$ of the global market for gums and resins except gum arabic, its share increased in value by $14 \%$ and $24 \%$ for the periods $2001-$ 2005 and 2004-2005, respectively.

The world's leading exporter of all natural gums and resins other than gum arabic (Pakistan) supplied 21962 tonnes in 2005 (Table 4.2). This amount is small compared with Ethiopia's estimated potential of 70650 tonnes.

Many countries import gum resin products from Ethiopia (Table 4.3). The major destinations are the United Arab Emirates (18.39\% of exports), Germany (14.43\%), Tunisia (13.45\%), China (9.43\%) and Greece (5.94\%). Together, these countries account for $61.64 \%$ of Ethiopia's total gum and resin exports (Table 4.3). 

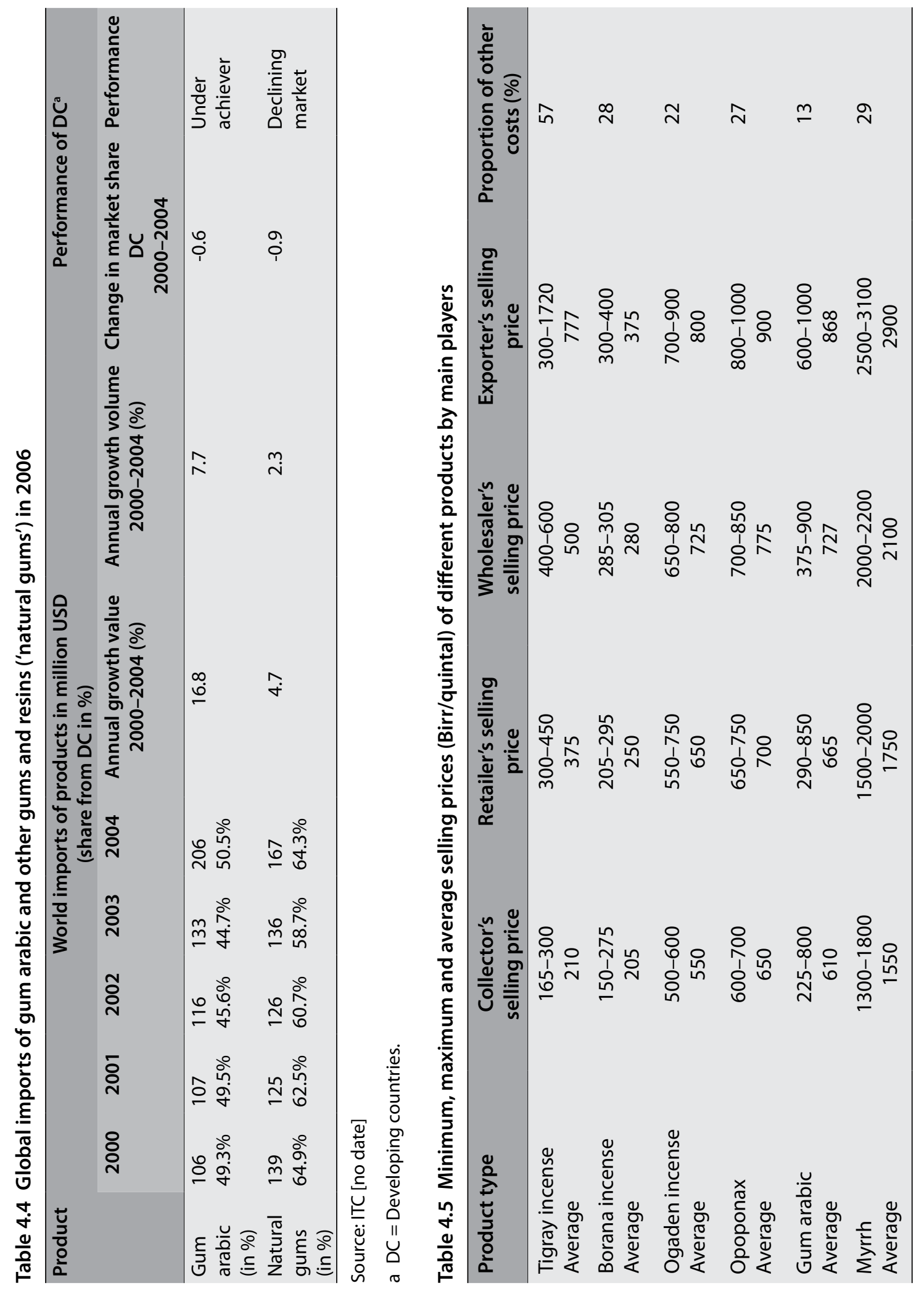


\subsubsection{International demand}

Gums and resins are required around the world both for traditional use in churches, mosques and households and for use in industrial processes. The competitive advantage of gums and resins compared with their substitutes is that they are natural and free from chemical modifications. Nevertheless, the market fluctuates: in the period 2000-2004, the natural gums market value declined in 2000-2001 and increased in 2002-2004, although the market for gum arabic grew throughout this period. In 2000-2003, the proportion of imports from developing countries decreased for gums and resins but remained nearly the same for gum arabic; in 2004, the proportion rose for all types. Imports of gum arabic and other gums and resins on average increased by $16.8 \%$ and $4.7 \%$ in value, respectively, and $7.7 \%$ and $2.3 \%$ in volume, respectively (Table 4.4 ).

\subsection{Marketing chain}

The marketing chain involves the flow of gum and resin products from producers/collectors to consumers and domestic or export markets through intermediary enterprises, wholesalers and retailers. Current marketing chains for the major gum and resin products of Ethiopia can be categorised into 4 groups according to product type and players:

- exporters directly producing and selling directly to consumers (mono actor);

- cooperatives producing and selling to gum companies (exporters), which then sell to consumers;

- individual collectors submitting to cooperatives, which then sell to gum companies, and then finally to consumers; and

- farmers/pastoralists collecting selling to rural retailers, which then sell to wholesalers and onto exporters and finally to consumers.

The first three models are common to Tigray type incense, whereas the fourth and longest chain is common to southern gum and resin products. The long chain creates additional costs, which increases sale prices along the chain (Table 4.5).

As shown in Table 4.5, the average selling prices of Tigray type olibanum, Borana type olibanum, Ogaden type olibanum, opoponax, gum arabic and myrrh increased by $270 \%, 83 \%, 45 \%, 38 \%, 42 \%$ and $68 \%$, respectively, between the collector/producers and exporters. However, the share of costs other than production increased by $35 \%, 13 \%, 14 \% 16 \%, 11 \%$ and $12 \%$, respectively. This indicates that increases in the number of intermediaries in market chain lead to high price increments. Other reasons for the price increments are collectors' lack of access to market information and variations in product quality. 


\section{References}

Al-Harbi, M.M., Qureshi, S., Raza, M., Ahmed, M.M., Afzal, M. and Shah, A. 1997 Gastric anti-ulcer and cytoprotective effect of Commiphora molmol in rats. Journal of Ethnopharmacology 55: 141-150.

Al-Harbi, M.M., Qureshi, S., Raza, M., Ahmed, M.M., Giangreco, A.B. and Shah, A.H. 1994 Anticarcinogenic effect of Commiphora molmol on solid tumors induced by Ehrlich carcinoma. cells in mice. Chemotherapy 40: 337-347.

Freese, B. L. 1996 News brief-medicinal myrrh. Archaeology 49(3).

Bhatt, J.R., Nair, M.N.B. and Mohar Ram, H.Y. 1989. Enhancement of oleo-gum resin production in Commiphora wightii by improved tapping technique. Current Science 58(7): 349-357.

Bradley, P.R. 1992 British herbal compendium, volume 1. British Herbal Medicine Association, Bournemouth, UK.

Braun, R. et al 1997 Standardzulassungen für Fertigarzneimittel: Text und Kommentar. Deutscher Apotheker, Stuttgart, Germany.

Bruneton, J. 1995 Pharmacognosy, phytochemistry and medicinal plants. Lavoisier, Paris.

Budavari, S. 1996 The Merck Iindex: an encyclopedia of chemicals, drugs and biologicals. 12th ed. Merck and Company, Whitehouse Station, NJ, USA.

Casadei, E. 1997 International regulations for natural products used as food additives. In: Mugah, J.O., Chikamai, B.N., Mbiru, S.S. and Casadei, E. (eds) Conservation, management and utilization of plant gums, resins and essential oils. Proceedings of a regional conference for Africa. Nairobi, Kenya, 6-10 October.

Claeson, P., Andersson, R. and Samuelsson, G. 1991 T-Ccadinol: a pharmacologically active constituent of scented myrrh: Iintroductory pharmacological characterization and high field $1 \mathrm{H}$ - and $13 \mathrm{C}-\mathrm{nmr}$ data. Plant Medicine 57: 352-356.

Coppen, J.J.W. 1995 Flavours and fragrances of plant origin. Non-wood forest products series, no. 1. Food and Agriculture Organization of the United Nations, Rome. 101p.

Coppen, J.J.W. 2005 Overview of international trade and markets. In: Chikamai, B. and Casadei, E. (eds) Production and marketing of gum resins: frankincense, myrrh and opoponax, p. 5-34. NGARA Publication Series 5. Network for Natural Gums and Resins in Africa, Nairobi, Kenya.

Cossalter, C. 1991 Acacia senegal: gum tree with promise for agroforestry. NFT Highlights, Nitrogen Fixing Tree Association No. 91-102.

Dolara, P., Luceri, C. and Ghelardini, C. 1996 Analgesic effects of myrrh. Nature 376: 29.

Duwiejua, M., Zeitlin, I.Z., Waterman, P.G., Chapman, J., Mhango, G.J. and Provan, G.J. 1993 Anti-inflammatory activities of resins from some species of the plant family Burceraceae. Planta Medicine 59: 12-16. 
Food and Agricultural Organization of the United Nations (FAO) 1988 Non-wood forest product in Ethiopia assignment to compile data, Addis Ababa, Ethiopia.

Food and Agricultural Organization of the United Nations (FAO) 1995. Flavours and fragrances of plant origin. Non-wood forest products 1. FAO, Rome.

Farah, A.Y. 1994 The milk of the Boswellia forests: frankincense production among the pastoral Somali. In: Ornäs, T.R.H. (ed.)Environmental policy and society. Uppsala University, Uppsala, Sweden.

Fragrance Foundation 1983 The Fragrance Foundation Reference Giude. Fragrance Foundation, New York.

Fratkin, J. 1986 Chinese herbal patent formulas: a practical guide. Shya Publications, Boulder, CO, USA.125-134 and 142-148

Frawley, D. and Lad, V. 1986 The yoga of herbs: an Ayurvedic guide to herbal medicine. Lotus Press, Twin Lakes, WI, USA.

Glaser, T., Winter,S., Groscurth, P., Safayhi, H., Sailer, E.R., Ammon, H.P., Schabet, M. and Weller, W. 1999 Boswellic acids and malignant glioma: induction of apoptosis but no modulation of drug sensitivity. British Journal of Cancer 80(5/6): 756-765. doi: 10.1038/sj.bjc.6690419.

Gupta, I., Gupta, V., Parihar, A., Gupta, S., Ludtke, R., Safayhi, H. and Ammon, H.P. 1998 Effects of Boswellia serrata gum resin in patients with bronchial asthma: results of a double-blind, placebo-controlled, 6-week clinical study. European Journal of Medical Research 3: 511-514.

Gupta, I., Parihar, A. and Malhotra, P. 1997 Effects of Boswellia serrata gum resin in patients with ulcerative colitis. European Journal of Medical Research 2:37-43.

Murthy, T.K. and Shiva, M.P. 1977 Salai guggul from Boswellia serrata Roxb. - its exploitation and utilisation. Indian Forester 103(7): 466-473.

Gupta, I., Parihar, A., Malhotra, P., Gupta,S., Ludtke, R., Safayhi, H. and Ammon, H.P.T. 2001 Effects of gum resin of Boswellia serrata in patients with chronic colitis. Planta Medica 67:391-395.

Hoernlein, R.F., Orlikowsky, T., Zehrer, C., Niethammer, D., Sailer, E.R., Simmet, T., Dannecker, G.E. and Ammon, H.P. 1999 Acetyl-11-keto-beta-boswellic acid induces apoptosis in HL-60 and CCRFCEM cells and inhibits topoisomerase. Journal of Pharmacology and Experimental Therapy 288: 613-619.

Huang, M.-T., Badmaev, V., Ding, Y., Liu, Y., Xie, J-G. and Ho, C.-T. 2000 Anti-tumor and anti-carcinogenic activities of triterpenoid, -boswellic acid. Biofactors 13:225-230.

International Trade Centre (ITC) [no date] Product Map. United Nations Conference on Trade and Development and World Trade Organisation. http://www.p-maps.org (December 2006).

Karamalla, A. 1997 The chemical characterization of myrrh and frankincense and opportunities for commercial utilization. In: Conservation, management and utilization of plant gums, resins and essential oils. Proceedings of a regional conference for Africa, Nairobi, Kenya, 6-10 October. 
Krieglstein, F.C., Anthoni, K., Rijcken, E.J.M., Laukötter, M., Spiegel, H.U. and Boden, S.E. (2001). Acetyl-11-keto- $\beta$-boswellic acid, a constituent of a herbal medicine from Boswellia serrata resin, attenuates experimental ileitis. Nant glioma: induction of apoptosis but no modulation of drug sensitivity. British Journal of Cancer 80:, 756-765.

Lata, S., Saxena, K.K., Bhasin, V., Saxena, R.S., Kumar, A. and Srivastava, V.K. 1991 Beneficial effects of Allium sativum, Allium cepa and Commiphora mukul on experimental hyperlipidemia and atherosclerosis-a comparative evaluation. Journal of Postgraduate Medicine 37: 132-135.

Leung, A.Y. 1980 Encyclopaedia of common natural ingredients used in food, drugs and cosmetics. John Wiley, New York.

Leung, A.Y. and Foster, S. 1996 Encyclopaedia of common natural ingredients used in food, drugs and cosmetics, $2 \mathrm{~d}$ ed. John Wiley \& Sons, New York.

Malhotra, S.C., Anuja, M.M. and Sundaram, K.R. 1977 Long- term clinical studies on the hypolipidaemic effect of Commiphora mukul (guggulu) and clofibrate. Indian Journal of Medical Research 65: 390-395.

Massoud, A. Sisi, S.E., Salama, O. and Massoud, A. 2001 Preliminary study of therapeutic efficacy of a new fasciolicidal drug derived from Commiphora molmol (myrrh). American Journal of Tropical Medicine and Hygiene 65(22): 96-99.

Massoud, A., Salama, O. and Bennett, J.L. 1998 Therapeutic efficacy of new schistosomicidal drug, derived from myrrh, in active intestinal schistosomiasis complicated with hepato-splenomegaly. In: Proceedings of the 9th International Congress of Parasitology, 619-623. Monduzzi Editores, Bologna, Italy.

Michie, C.A. and Cooper, E. 1991. Frankincense and myrrh as remedies in children. Journal of the Royal Society of Medicine 84((110): 602-605.

Mielck, W. 1970 Merfluan: ein brausendes Zahnsalz mit Myrrhe [Merfluan-an effervescent dentifrice salt with myrrh]. Dental Dienstag 22(11): 21.

Ministry of Trade and Industry 2006 (http://www.ethiopia.gov.et/English/MOTI/ Pages/Home.aspx (December 2006).

Qureshi, S., Al-Harbi, M.M., Ahmed, M.M., Raza, M., Giangreco, A.B. and Shah, A.H.1993 Evaluation of the genotoxic, cytotoxic and antitumor properties of Commiphora molmol using normal and Ehnrlich ascites carcinoma cellbearing Swiss albino mice. Cancer Chemotheraphy and Pharmacology 33: $130-138$.

Rao, R.M., Khan, Z.A. and Shah, A.H. 2001 Toxicity studies in mice of Commiphora molmol oleo-gum resin. Journal of Ethnopharamacology 76: 151-154.

Safayhi H., Boden, S.E., Schweizer, S. and Ammon, H.P. 2000 Concentration dependent potentiating and inhibitory effects of Boswellia extracts on 5-lipoxygenase product formation in stimulated PMNL. Planta Medica 66: $110-113$. 
Schilcher, H. 1997 Phytotherapy in paediatrics:handbook for physicians and pharmacists. Medpharm Scientific, Stuttgart, Germany.

Shao, Y., Ho, C.T., Chin, C.K., Badmaev, V., Ma, W. and Huang, M.T. 1998 Inhibitory activity of Boswellic acids from Boswellia serrata against human leukaemia HL-60 cells in culture. Planta Medicine 64: 328-331.

Singh, G.B. and Atal, C.K. 1986 Pharmacology of an extract of salai guggal exBoswellia serrata, a new non-steroidal anti-inflammatory agent. Agents Actions 18:407-412.

Tadele, W. and Onno, R. 2005 Gums, naturally? export potential of Ethiopian gums. Ethiopia Promotion Department, Addis Ababa, Ethiopia.

Tariq, M., Ageel, A.M., Al-Yahya, M.A., Mossa, J.S., Al-Said, M.S., and Parmar, N.S. 1985 Anti-inflammatory activity of Commiphora molmol. Agents and Actions 17(3/4): 381-382.

Tucker, A.O. 1986 Frankincense and myrrh. Economic Botany 40(4): 425-433.

Tyler, V.E. 1993 The honest herbal. 3rd ed. Pharmaceutical Products Press, New York.

Wahab, S.M.A., Aboutabl, E.A., El-Zalabani, S.M., Fouad, H.A., De Pooter, H.L. and El-Fallaha, B. 1987 The essential oil of olibanum. Planta Medica 53(4): 382-384.

Wichtl, M., and Bisset, N.G. 1994 Herbal drugs and phytopharmaceuticals. Medpharm Scientific, Stuttgart, Germany.

Yamada, T., Deitch, E., Specian R.D., Perry M.A., Sartor, R.B. and Grisham, M.B. 1993 Mechanisms of acute and chronic intestinal inflammation induced by indomethacin. Inflammation 17:641-662.

Yen, K.Y. 1992 The illustrated Chinese materia medica: crude and prepared. SMC Publishing, Taipei, Taiwan. 



\section{Chapter 5}

\section{Challenges, opportunities and actions for sustainable gum and resin production}

Mulugeta Lemenih ${ }^{1}$ and Habtemariam Kassa ${ }^{2}$

\subsection{Challenges and opportunities}

Ethiopia's dry forests are notably important natural resource endowments of drylands that have long contributed to human welfare and environmental health. In addition to their direct and indirect support of the livelihoods of $15-20 \%$ of Ethiopia's population, their commercial gum and resin products make them socio-economically important resources beyond the local level. These products are generating considerable foreign currency earnings for the country, and thus government and business interest in boosting production is growing. The government has targeted dry forests in its strategy to diversify its export goods to secure foreign currency (PASDEP 2005). Such intensified interest can lead to short- or medium-term changes to existing management and production systems. Decentralised (region-based) resource governance and improved regulatory frameworks are also showing signs of creating more responsible resource-base management and production systems.

The contribution of gums and resins to local livelihoods is increasing. This is expected to stimulate improved, locally evolving resource ownership, as shown in the emerging domestication of the resources such as in Tigray. Private sector involvement in the industry is increasing, and NGOs are intensifying their efforts to improve management of the resources for sustainable livelihoods. Overall, the growing interest from all sides - government, NGOs, private entrepreneurs - is likely to increase the economic and social benefits derived from these resources and consequently their management.

Nevertheless, despite the growing local and national importance of the gums and resins subsector, several factors continue to hamper sustainable management of the resource base:

1 Hawassa University, Wondo Genet College of Forestry and Natural Resources, Ethiopia

2 Center for International Forest Research (CIFOR) 
- climate change, political agenda or national economic policies and market forces that are forcing adaptation through new livelihood activities, particularly shifts towards increased crop cultivation;

- cultural transformations occurring through the penetration of urbanization, foreign religions, formal education and increased interaction with outside communities that are collectively weakening traditional cultural systems of resource management; and

- the shift from communal ownership and management of the resources through indigenous institutions to more individualistic and private-based ownership and management.

The following sections set out a SWOT analysis of the current resource management and exploitation systems to examine the existing strengths to build upon, weaknesses to avoid, opportunities to grasp and threats to prepare for.

\subsubsection{Strengths of the gums and resins subsector}

Following are indicators of the strengths of Ethiopia's gums and resins subsector.

- Economic incentives from the subsector are attracting increasing private investment.

- Growing recognition of the importance of the resources to rural livelihoods and environmental quality is spurring increased involvement of development partners such as NGOs in supporting local efforts and national and/or regional government initiatives for improved management and exploitation of the resources.

- The use of gum producing species for gum-resin exploitation when done properly is environmentally friendly and can allow the country to comply with the international agreements it has signed, such as the CCC, CBC and CCD.

- The resources have multiple values and functions, including providing fodder for livestock production, wood for charcoal and nectar for apiculture; this can encourage improved integrated management as a climate change adaptation mechanism, a route that several donors are interested in and seeking to pursue.

- The country has an efficient loan provision system and availability of credit for those interested in investing in the subsector.

- The subsector can attract research and development efforts at various scales. 


\subsubsection{Weaknesses of the gums and resins subsector}

Despite the considerable importance of the gums and resins subsector to Ethiopia's local and national economies, the following factors constrain the proper use of resources.

- Infrastructure development and access to areas where gum- and resinproducing trees grow are poor. This leads to higher energy costs, which eats into profits and can discourage investment in the subsector.

- In their natural form, gum-producing trees are scattered across wide areas located in hot climates and mostly on rugged land. Consequently, production is arduous and labour intensive and the subsector is less competitive in attracting labour. These limitations coupled with low product prices may discourage many private companies from continuing their involvement in the subsector.

- Despite the long tradition, ambiguities in access rights and ownership lead to unsustainable and irresponsible exploitation and resource degradation.

- Poor handling and lack of quality control, especially for products from the Borana area, are obstacles to improved and sustainable marketing.

- The slow process of land leasing and lack of monitoring over production processes are allowing over-exploitation, thus damaging the natural stock.

- Lack of value-added processing that weakens income gain from the resources.

- Low community mobilisation and involvement in the management and protection of the resources.

\subsubsection{Opportunities}

The following points describe opportunities for better and sustainable development and exploitation of the gums and resins subsector.

- Improved recognition of the contribution of the resources to rural livelihoods and the national economy and their potential in sustainable land management, which has been incorporated into Ethiopia's current national strategy (PASDEP) as well as several international conventions such as desertification control.

- Increased government attention to the resources for diversification of export products and, consequently, growing encouragement and various incentives such as tax exemptions for importation of goods needed for the production and management of the resources for those investing in the development of the resources. This could encourage entrepreneurs to invest in developing the resources.

- The existence of a long tradition and rich indigenous knowledge regarding the biology and silvics of the woodlands and their species. 
- $\quad$ Strong market demand at domestic and international levels. Growing consumer interest in organic/natural products is boosting demand for products from Ethiopia.

- Organic/natural products could attain higher prices through certification.

- Establishment of Global Mechanisms for securing funding for dryland management; several NGOs and bilateral and multilateral donors can support development initiatives related to dry forest management.

- Extraction of gums and resins is not destructive to the tree and the vegetation ecosystem can also benefit from other global opportunities such as REDD (carbon funds).

- Exemptions from import duties applied for Ethiopia in the US and EU markets.

- Developing countries, mainly Africa, have a considerable share of the gum and incense market, particularly gum arabic and frankincense.

- Value-added processing is possible and will boost returns from the subsector.

- Global demand for gums and resins is rising.

- The policy of private sector-driven development in the country and the growing involvement by private entrepreneurs in the subsector that boosted production and trade.

- Several regional and international institutions exist that can contribute towards the development of the resources, such as Global Mechanisms to facilitate and support fund-raising for national projects, Network for Natural Gums and Resins in Africa (NGARA) to support provision of market information, networking, etc.

- The country has sufficient labour to engage in the large-scale management or exploitation of resources if properly organised and mobilised.

\subsubsection{Threats}

The following points hinder the achievement of optimal and sustainable use of gum and resin resources, thereby reducing the benefits that the subsector could generate. It is necessary to address and mitigate these threats to ensure enhanced, sustainable benefits from the subsector.

- Climate change, increasing global food and energy prices and low product prices could reduce interest in the management of gum and resin resources.

- Excessive firewood harvesting and improper tapping practices damage trees and reduce their population in the woodlands .

- The area is under intensive grazing, as most herders keep their livestock there. 
- Unintentional wounding of trees by herders and improper wounding of trees by local collectors.

- High intensity of forest fires and agricultural expansion.

- Conflicting policies, programmes and strategies, particularly the impact of non-forestry policies such as resettlement, and economic and rural development policies and strategies.

- Changing role of traditional resource management institutions due to exogenous factors.

- Uncontrolled migration and poor legal and regulatory systems, leading to open access to the resource base.

- Low financial and technical capacity of most private entrepreneurs currently interested in the subsector, particularly with regard to engagement in valueadded processing and large-scale development activities.

- Population growth and associated migration to the lowlands in search of livelihoods from natural resource exploitation.

- Ongoing land and environmental degradation in the highlands that necessitates large-scale resettlement programmes to the lowlands.

- Climate change, frequent drought, poor performance of the livestock sector will drive further woodland clearance.

- Increasing global prices for food and energy products could accelerate the conversion of woodlands to other forms of land use and expand the use of wood resources for energy.

\subsection{Future actions}

Ethiopia's naturally growing gum and resin resource base is abundant, and the country has a vast area suitable for developing these resources. Production of gums and resins has increased during recent decades and it is expected to intensify as national economic development initiatives increase pressure on the natural resource base for intensive exploitation. Designing and implementing sustainable production systems is necessary not only to conserve the resources but also to enhance their sustainable socio-economic and ecological significance. To achieve these dual goals, it is essential to implement concerted and integrated multidimensional management interventions. Such interventions require multiinstitutional collaboration and integration of actions to optimise impacts for the sustained production and development of the resources. Activities may be shared among various institutions and stakeholders at federal, regional and local levels, including the private sector. Following are some priority activities recommended for interventions in the short and medium term. 
- Conducting a national-scale resource inventory (ground and/or remote sensing based), assessing with a high level of accuracy the available resource base in order to provide the business community with reliable information on the quantity, type and quality of currently marketable gum and resin products as well as potentially suitable areas for future development.

- $\quad$ Training and retraining of producers and traders to increase awareness of the need for sustainable management, to build and improve the capacity and technical skills of all concerned (local and business community and development/extension agents) in terms of silvicultural management techniques and to establish systems for ongoing support in managing dryland resources.

- Training and retraining producers in quality control, handling and transport of gum and resin commodities.

- Creating sufficient incentives and promoting sustainable dryland vegetation management through improved and sustained market links, market networks and timely provision of market information.

- Facilitating and supporting the establishment of transparent and effective producers and traders associations and strengthening their function through ongoing technical support.

- $\quad$ Strengthening the collaboration of pertinent institutions in relation to appropriate research to advance the management, production and commercialisation of gums and related dryland products.

- Creating the required infrastructure for documentation and dissemination of information, best practices and lessons learnt from within and outside the country in areas related to gum and other dryland product management and commercialisation.

- Aggressively pursuing value-added processing at various scales to enhance economic gains from the products and create more employment opportunities, while also creating inland capacity for further finished product processing and exports.

- Working collaboratively to tap into Global Mechanisms to channel some essential funds for development in the drylands.

The following more specific and short-term recommendations are also worth outlining.

- $\quad$ Production processes should be closely monitored and trees should be rested for a sufficient period to allow them to recover and regenerate.

- Producers should be given long leases and should be made accountable for changing forest conditions in their respective production areas. For this, monitoring systems need to be established and enforced. 
- Ways to engage local communities in the management, production and benefits of the subsector should be seriously considered. Transferring responsibility for forest governance to locals is the best way to fill the institutional vacuum that leads to proper access to resources and thus reduces unsustainable exploitation of the resources; in particular, overgrazing and clearance should be minimised.

- Resettlement should be mainstreamed with improved management and conservation of the forest ecosystem. The resettlers can be organised, trained and thus engaged in the production of gums and resins as well as in complementary activities such as animal husbandry and apiculture that are dry forest ecosystem friendly.

Training and retraining producers in best-practice handling, storage and transportation, including ways to avoid adulteration, are essential steps in building a strong reputation, gaining a sustainable market and competing with other producing countries in the global market. 


This publication is intended to serve researchers and teachers as well as development practitioners. It was prepared based on requests from CIFOR's national partners in Ethiopia and the region to compile existing information and help address the lack of documents available for teaching graduate and undergraduate students about the management of forests in dryland areas in general, and the production and marketing of gums and resins in particular.

By describing the current status of the dry forest resource base and the production and marketing of gums and resins, this publication contributes toward filling the existing knowledge gap. Chapter 1 presents an overview of challenges and forest-based opportunities in the drylands of Ethiopia. Chapter 2 describes in detail the resource base of gums and resins as well as the challenges to their productivity. Chapter 3 discusses production, handling and quality control, while Chapter 4 addresses value-added processing and the marketing of gums and resins. Finally, Chapter 5 summarises challenges and opportunities as well as actions for sustainable gum and resin production.

\section{Sida \\ Austrian \\ Development Cooperation}

